UNIVERSIDADE DE SÃO PAULO

FACULDADE DE EDUCAÇÃO

\title{
ERICA BENVENUTI
}

\section{Educação e Política em Hannah Arendt:}

\author{
um sentido político para a separação
}

São Paulo

2010 


\section{ERICA BENVENUTI}

\section{Educação e Política em Hannah Arendt:}

\section{um sentido político para a separação}

Dissertação apresentada à Faculdade de Educação da Universidade de São Paulo para a obtenção do título de Mestre em Educação.

Área de Concentração: Filosofia da Educação

Orientador: Prof. Dr. José Sérgio Fonseca de Carvalho

São Paulo

2010 
AUTORIZO A REPRODUÇÃO E DIVULGAÇÃO TOTAL OU PARCIAL DESTE TRABALHO, POR QUALQUER MEIO CONVENCIONAL OU ELETRÔNICO, PARA FINS DE ESTUDO E PESQUISA, DESDE QUE CITADA A FONTE.

Catalogação na Publicação

Serviço de Biblioteca e Documentação

Faculdade de Educação da Universidade de São Paulo

$37.01 \quad$ Benvenuti, Erica

B478e Educação e política em Hannah Arendt: um sentido político para a separação / Erica Benvenuti; orientação José Sérgio Fonseca de Carvalho.

São Paulo: s.n., 2010.

$118 \mathrm{p}$.

Dissertação (Mestrado - Programa de Pós-Graduação em Educação. Área de Concentração: Filosofia da Educação) - - Faculdade de Educação da Universidade de São Paulo.

1. Filosofia da educação 2. Política 3. Responsabilidade 4. Arendt, Hannah I. Carvalho, José Sérgio Fonseca de, orient. 


\section{FOLHA DE APROVAÇÃO}

BENVENUTI, E. Educação e Política em Hannah Arendt: um sentido político para a separação. Dissertação apresentada à Faculdade de Educação da Universidade de São Paulo para a obtenção do título de Mestre em Educação.

Aprovado em:

Banca Examinadora

Prof. Dr. Instituição:

Julgamento: Assinatura:

Prof. Dr. Instituição:

Julgamento: Assinatura:

Prof. Dr. Instituição: Assinatura: 
Àqueles que me trouxeram ao mundo, e foram os primeiros a me ensinar a amá-lo 


\section{AGRADECIMENTOS}

Agradeço ao Diego por suportar a solidão com um sorriso e por compreender com amor;

ao Prof. José Sérgio pela companhia e por ser sempre um exemplo de amor mundi manifesto em sua inabalável fidelidade à tarefa de ser professor;

aos colegas e amigos do grupo de estudos, que me ensinaram a "pensar junto" (embora Arendt discordasse dessa possibilidade);

à Faculdade de Educação, que me formou;

aos meus familiares e amigas: pacientes com meus devaneios e ausências (em especial Fabiane e Tatiane, que contribuíram de alguma forma com o produto final deste estudo, e à Silvia, que se arriscou a sonhar comigo).

Por fim, agradeço, de coração, a todos aqueles que algum dia me disseram que era possível. 
É perfeitamente certo o que você diz acerca das distinções. Sempre que começo algo - nunca gosto de saber muito bem o que estou fazendo -, o faço dizendo 'A e B não são o mesmo'. 


\section{RESUMO}

\section{BENVENUTI, E. Educação e Política em Hannah Arendt: um sentido político para a}

separação. 2010. 118 f. Dissertação (Mestrado) - Faculdade de Educação, Universidade de São Paulo, São Paulo, 2010.

Este trabalho apresenta uma reflexão sobre a relação entre a educação e a política a partir do pensamento de Hannah Arendt. Em seus escritos encontramos afirmações de separação radical entre a educação e a política, algo incomum nos discursos correntes de ambas as áreas. Apesar dessas afirmações, Arendt reflete sobre a crise da educação a partir de suas considerações sobre a política e a crise do mundo moderno, afirmando que a situação da educação é um problema político. Além disso, a autora considera a natalidade a essência da educação, conceito que também é central em sua compreensão sobre a política. Outro elemento que encontramos em seus escritos é o uso da expressão pré-política para referir-se à educação. Algumas perguntas, então, motivam as reflexões neste trabalho: o que significam, no pensamento da autora, as afirmações que distanciam tão fortemente a educação da política? Como a crise na educação pode ser tida como um problema político se estes são dois âmbitos separados? Como a natalidade - conceito político em Arendt - pode ser considerada por ela a essência da educação? Por que Arendt se refere a ela como sendo um âmbito prépolítico? Este trabalho, portanto, se traduz numa reflexão sobre a ideia de educação em Hannah Arendt realizada a partir do conjunto de seu pensamento político, sempre preservando a distinção estabelecida entre estes âmbitos. São apresentadas relações entre a educação e a política a partir da responsabilidade que ambas assumem pelo mundo (de maneira complementar e distinta), identificando também a condição de antecedência necessária da educação em relação à política na medida em que, ao apresentar o mundo, o conserva (para que este possa seguir sendo o palco e o centro da política). Por fim, apresentamos reflexões que revelam as razões de a crise na educação ser um problema político e que, portanto, envolve discussões de ordem política em função da abertura que a atual crise do mundo provoca.

Palavras-chave: Filosofia da Educação. Política. Hannah Arendt. Responsabilidade. 


\begin{abstract}
BENVENUTI, E. Education and Politic in Hannah Arendt: a political sense to separate. 2010. 118 f. Dissertação (Mestrado) - Faculdade de Educação, Universidade de São Paulo, São Paulo, 2010.

This work introduces a reflection about the relationship between education and politics coming from the teachings of Hannah Arendt. In her writings one finds statements about a radical separation of education and politics, something unusually found in the discourse of both fields. Despite these assertions, Arendt reflects about the crisis of education from her considerations about politics and the crisis of the modern world, claiming that the current educational situation is a political problem. In addition to this, the author considers natality to be the essence of education, a concept which is also central in her understanding of politics. Another element we find in her writings is the use of the expression pre-politics to refer to education. Some questions, then, motivate the inquiries in this work: what do the assertions which so strongly set politics and education apart mean in the author's thinking? How can the crisis in education to be considered a political problem if these are two separate areas? How can natality - a political concept for Arendt - be considered the essence of education? Why does Arendt refer to it as being a pre-political realm? This investigation, therefore, can be translated into an inquiry about the idea of education in Hannah Arendt realized from the conjunction of her political thought, preserving the distinction between these two fields. There are considerations about the relationship between education and politics from the responsibility both take for the world (in distinct and complementary ways), respecting the precedent condition of education in relation to politics, as the former introduces the world, conserving it ( so that it can be the stage and the center of politics). Lastly, there are reflections which present the reasons why the crisis of education is indeed a political problem and henceforth involves political discussions in function of the opening promoted by the current crisis of the world.
\end{abstract}

Key-words: Philosophy of Education. Politics. Hannah Arendt. Responsibility. 
SUMÁRIO

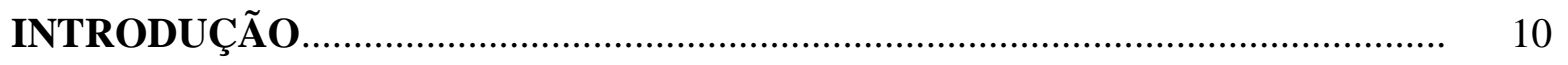

1. A CONDIÇÃO HUMANA E A POLÍticA: ALGUNS CONCEITOS FUNDAMENTAIS.

1.1 “A política baseia-se no fato da pluralidade humana.” ....................................... 16

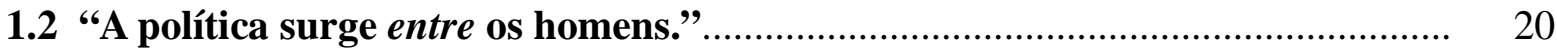

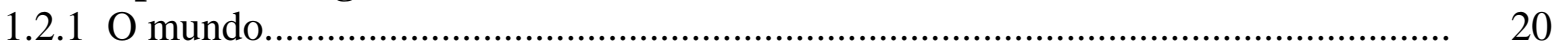

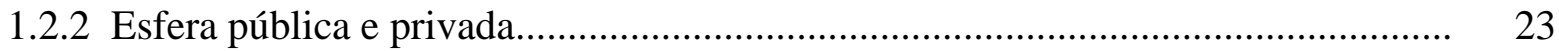

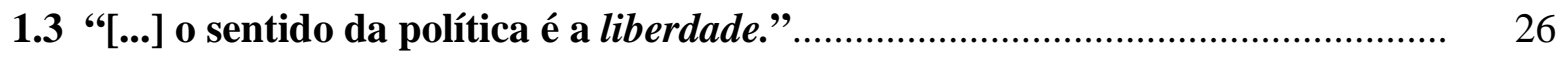

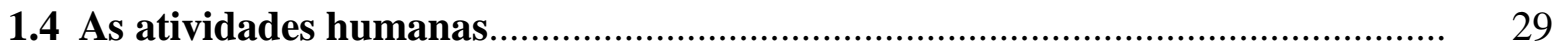

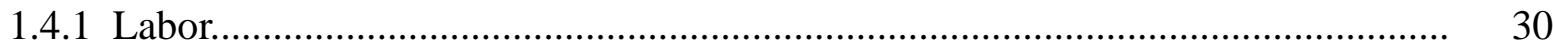

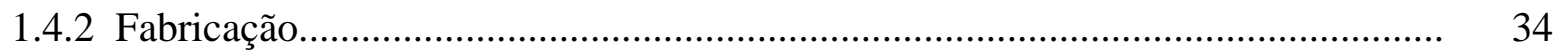

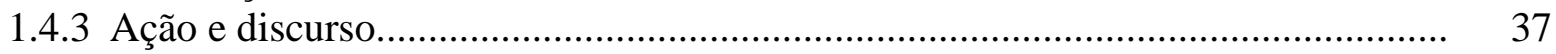

2. EDUCAÇÃO E POLÍTICA: RELAÇÕES A SEREM COMPREENDIDAS..... 43

2.1 A educação no pensamento de Hannah Arendt e sua separação da política...... 43

2.2 As relações existentes entre o que é pré-político e a própria política................. 48

3. O CONCEITO DE NATALIDE E A RESPONSABILIDADE PELO MUNDO. 59

3.1 O conceito de natalidade na política e na educação........................................... 59

3.2 A responsabilidade pelo mundo advinda da natalidade .................................... 62

4. A CRISE NA EDUCAÇÃO, UM PROBLEMA POLÍTICO............................... 80

4.1 A crise do mundo moderno e a ausência de mundo........................................... 80

4.2 A crise na educação e a abertura para discussões políticas............................... 99

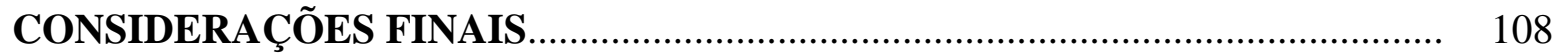

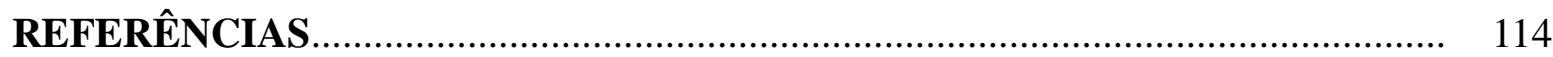




\section{INTRODUÇÃO}

A ideia de que a educação é uma atividade política é parte dos discursos correntes de ambas as áreas. Estes frequentemente veiculam que a educação tem a capacidade de transformar - ou manter - o entorno político: ou por meio das ideologias que a perpassam, ou através das ideias e conhecimentos que comunica. Essas concepções de educação comumente atribuem a ela e aos educadores não onipotência, mas sim grande poder e responsabilidade diante das falências e sucessos de um povo ou nação.

Assim, é fundamental, tanto para o campo da educação quanto para o da política, nos dedicarmos a compreender a variedade desses discursos e os princípios que os movem. A relevância de analisá-los na área da pedagogia está no fato de que oferecem um sentido, cada um à sua maneira, para a tarefa de educar e ser professor, apontando para os supostos significados e alcances da responsabilidade que a educação assume. Já no campo da política, a relevância desses estudos está em identificar aqueles que possivelmente venham a justificar a redução das possibilidades de ação no tratamento das questões de nosso mundo, que, sem dúvida, são parte de discussões mais complexas, devendo ser enfrentadas nesse âmbito. Nesses discursos, a educação frequentemente é entendida como uma potencial agente salvadora das condições indesejáveis na qual se encontra determinada comunidade política (ou como forte instrumento de sua manutenção). Não sem razão, no mundo contemporâneo, a ausência de sentido de que padecem tanto a educação quanto a política conduz a uma confusão e identificação entre os dois âmbitos, como se a educação pudesse ser aquilo de que a política não tem se mostrado capaz.

Hannah Arendt, pensadora que teve a experiência dos regimes totalitários como disparadora de seus escritos sobre política, não se dedicou a pensar longamente sobre a educação. No entanto, encontramos em meio a sua obra afirmações que separam decisivamente os dois âmbitos, algo que frequentemente gera impacto e estranhamento entre os leitores. Sendo Arendt uma pensadora da política, sua reflexão sobre a educação se dá a partir de suas categorias conceituais e, portanto, políticas. Conceitos como o de natalidade, liberdade, mundo e ação estão marcadamente presentes na discussão sobre o tema. Além disso, a responsabilidade que Hannah Arendt atribui à educação parece relacionada (e não 
identificada) com a responsabilidade política pelo mundo em seu pensamento.

Dentre os trechos mais impactantes sobre a separação entre a educação e a política estão:

Cumpre divorciarmos decisivamente o âmbito da educação dos demais, e acima de tudo do âmbito da vida pública e política (ARENDT, 2005b, p. 246, grifo nosso).

O papel desempenhado pela educação em todas as utopias políticas, a partir dos tempos antigos, mostra o quanto parece natural iniciar um novo mundo com aqueles que são por nascimento e por natureza novos. No que toca à política, isso implica obviamente num grave equívoco [...]. A educação não pode desempenhar papel nenhum na política [...] (ARENDT, 2005b, p. 225, grifo nosso).

Apesar dessas afirmações, aos leitores atentos e minimamente conhecedores de sua obra dificilmente passam despercebidas outras de suas passagens que parecem anunciar outras relações entre a educação e a política. Torna-se inevitável deixar de reconhecer nelas algo de seu pensamento político, ou ainda deixar de notar que parecem representar uma ambiguidade diante das afirmações anteriores de separação radical entre esses âmbitos.

A perda geral de autoridade, de fato, não poderia encontrar expressão mais radical do que sua intrusão na esfera pré-política [...] (ARENDT, 2005b, p. 241, grifo nosso).

[...] a crise periódica na educação, [...] se tornou, no transcurso da última década pelo menos, um problema político de primeira grandeza [...] (ARENDT, 2005b, p. 221, grifo nosso).

[...] a essência da educação é a natalidade, o fato de que seres nascem para o mundo (ARENDT, 2005b, p. 223, grifo nosso).

Os cinco diferentes trechos já citados, e que encontramos em A Crise na Educação, ilustram o aparente conflito. Enquanto os dois primeiros apresentam a separação entre a educação e a política de maneira veemente, os três seguintes apontam para elementos que 
relacionam os dois âmbitos, dando a entender que há algo mais a ser compreendido a esse respeito do que o que encontramos expresso de forma explícita em seus escritos. Além disso, se voltarmos ao contexto dessas afirmações, notaremos a falta de tratamento que Arendt ofereceu ao assunto. Não encontramos em sua obra uma discussão realizada profunda e detidamente sobre a relação entre a educação e a política que se mostre suficientemente esclarecedora, o que mantém a abertura para a reflexão a respeito de como ela se estabelece.

É sobre a problemática dessa relação entre a educação e a política no pensamento de Hannah Arendt que nos dedicamos a refletir. Iremos, portanto, procurar compreender algumas das poucas referências ao tema que encontramos manifestas no conjunto de seus escritos, para estabelecermos um caminho de reflexão a partir de outros elementos de sua obra política que sejam capazes de iluminar o que permanece tão nebuloso em seus registros. Isso significa que, além de apontarmos para o que ela disse a respeito dessa relação entre a educação e a política, desenvolveremos também uma reflexão sobre o que não foi formulado explicitamente em sua obra, mas que pode vir a ser considerado a partir de seu pensamento. Portanto, além de desvelar, a partir dessa perspectiva, uma dimensão política para a educação com princípios e significados distintos dos que comumente encontramos em outros discursos, estabeleceremos a relação entre esses âmbitos a partir da separação e distinção que ela mesma determina, reconhecendo os limites da atividade educativa no que diz respeito à sua capacidade transformadora.

Algumas perguntas, então, motivam nossas reflexões: o que significam, no pensamento da autora, as afirmações que distanciam tão fortemente a educação da política? Como a natalidade - conceito político em Arendt - pode ser considerada por ela a essência da educação? Como a crise na educação pode ser tida como um problema político se estes são dois âmbitos separados? Por que Arendt designa a educação um âmbito pré-político? A partir dessas questões, este trabalho se traduz numa reflexão sobre a ideia de educação em Hannah Arendt realizada a partir do conjunto de seu pensamento político: trata-se de um exercício de compreensão sobre um problema interno do pensamento da autora que julgamos ser capaz de oferecer uma perspectiva diferente do que habitualmente encontramos nos discursos correntes sobre a relação entre a educação e a política. 


\section{A CONDiÇÃo hUMANA E A POLÍtica: ALgUNS CONCEITOS FUNDAMENTAIS}

O pensamento de Hannah Arendt adveio da aspiração pela compreensão do totalitarismo e da situação do mundo pós-totalitário. A perplexidade diante das situações políticas mais marcantes do século XX conduziram-na a uma reflexão profunda sobre o significado da própria política e sobre a condição da existência dos homens no mundo nesse cenário. Para realizar essa reflexão, a autora estabelece diálogo com o passado, buscando na história e na tradição do pensamento ocidental elementos que considera serem capazes de iluminar os fatos e experiências de seu tempo. Arendt, então, realiza um diálogo com a polis enquanto lugar de invenção da política; com a República Romana enquanto período de reinvenção da experiência política grega; com o impacto do cristianismo na maneira de os homens estabelecerem relação com o mundo; com o pensamento de homens que marcaram nossa tradição filosófica (de Sócrates aos modernos); e com muitos outros elementos da história que ela considerou serem capazes de lançar luz sobre os eventos políticos do mundo moderno para que pudesse compreendê-los. Desse exercício advém a elaboração de um pensamento em aberto, no qual não encontramos propostas ou definições de ação, mas sim um conjunto de conceitos que nos propicia uma reflexão singular sobre as questões que envolvem o nosso mundo.

Neste capítulo apresentaremos, em traços gerais, alguns dos conceitos de Hannah Arendt que são fundamentais para qualquer reflexão a ser realizada a partir de seu pensamento. Alguns desses conceitos são essencialmente políticos. Outros são fundamentais para a compreensão do que não é a política, segundo a autora, auxiliando-nos a estabelecer distinções. Mais tarde, esses conceitos fundamentarão também nossa reflexão sobre a educação e sua relação com a política. Embora para delimitá-los (especialmente em $A$ Condição Humana, mas também ao longo de toda a sua obra) Arendt tenha estabelecido o debate que mencionamos anteriormente com as mais diversas experiências e homens do passado, não nos interessa aqui apresentá-los com tanto detalhamento e profundidade. Em contrapartida, torna-se impossível apresentar tais conceitos sem qualquer referência do passado ou experiência iluminadora que nos auxilie na compreensão do que eles significam. Elegemos, então, a experiência da invenção da política na Antiguidade Grega para guiar nossa 
reflexão neste capítulo.

Segundo Vernant (2006), em As Origens do Pensamento Grego, a polis surgiu, entre os séculos VIII e VII a.C., como forma de resolução dos conflitos em torno da questão do governo nas comunidades gregas, provocados por uma crise administrativa que dividia a soberania em várias figuras com diferentes princípios. Essas diferenças, e a dificuldade em concentrar o governo nas mãos de uma única figura, geraram uma situação nova para a qual os gregos encontraram uma resposta até então inédita. Segundo o autor, com a ausência de um soberano

[...] novos problemas surgem: como a ordem pode surgir do conflito entre grupos rivais, do choque das prerrogativas e das funções opostas? Como uma vida comum pode apoiar-se em elementos discordantes? Ou [...] como, no plano social, o uno pode sair do múltiplo e o múltiplo do uno? Poder de conflito - poder de união (VERNANT, 2006, p. 48).

A política irrompe como maneira de conformação desse elemento uno a partir do diverso: nela o poder é gerado a partir da união dos homens. Cada polis tinha não só uma delimitação espacial própria, mas também de identidade a partir de sua fronteira física e legal. Seus muros forneciam o contorno de seu território; suas leis, suas regras, seu temperamento. Também o espaço dessas cidades ganhou forma nova: em vez de construir-se como antes, em torno de um palácio, estavam centralizadas na praça pública e se organizavam ao seu redor.

Nesse centro, os cidadãos - homens livres que tinham as necessidades da vida e do lar atendidas - reuniam-se para desempenhar atividade política. A ágora era o espaço da polis na qual ocorria esse encontro mediado exclusivamente pela palavra: nela eram discutidos os temas da cidade que diziam respeito à vida comum. Os temas eram as questões públicas e, portanto, dela estava excluído tudo que estivesse relacionado à vida individual ou às necessidades do lar, ou seja, aquilo que dissesse respeito ao âmbito privado. A ágora era, portanto, o lugar privilegiado dos assuntos públicos.

No âmbito privado, nas casas, cada um desses homens era senhor. Nelas as definições partiam dele - de uma única figura -, estando imposta no lar uma desigualdade de relações em que a palavra do patriarca estava imbuída de força e da autoridade advinda do próprio lugar que ocupava. Essa condição, porém, era abandonada por ele quando adentrava a ágora: nela todos se relacionavam como iguais. Aristóteles (2007, p. 22), em A Política, distingue a situação da autoridade desses homens nesses dois âmbitos da vida. "A autoridade doméstica é 
uma monarquia, pois toda família é governada por um só: a autoridade civil ou política é aquela que governa homens livres e iguais".

No governo da polis a palavra de todos tinha, em princípio, igual valor, e a capacidade de persuasão do discurso conduzia a definição acerca dos temas discutidos. A igualdade na qual se dispunham os cidadãos ao ocupar esse espaço era o que permitia a relação de persuasão pelo discurso: afinal, se houvesse desigualdade, as definições dar-se-iam pela simples imposição da força. O discurso - que pressupõe fala e escuta - não faria qualquer sentido:

[...] a política toma [...] forma de agón: uma disputa oratória, num combate de argumentos cujo palco é a ágora, a praça pública, lugar de reunião antes de ser um mercado. Os que se medem pela palavra, que opõe discurso a discurso, formam nessa sociedade hierarquizada um grupo de iguais. [...] A arché não poderia mais ser a propriedade exclusiva de quem quer que seja; o Estado é precisamente o que se despojou de todo caráter privado, particular, o que [...] já aparece como a questão de todos (VERNANT, 2006, p. 50).

Dessa condição de igualdade na ágora surgia o debate. Na praça pública os homens uniam-se em torno de algo e faziam uso da palavra com a intenção de persuadir. Não existia nela lugar para a violência (expressão da força) e o discurso mediava a experiência da união (mesmo que houvesse o confronto de ideias): era ele, então, a forma de realização da política. Assim se estabelece um novo começo para essas comunidades, e é a partir dessa perspectiva que Arendt tratará do tema da política. A ideia de início permeará todo o seu pensamento algo que veremos adiante ao tratarmos de alguns de seus conceitos fundamentais tanto da educação quanto da política.

[...] seu advento, que se pode situar entre os séculos VIII e VII, marca um começo, uma verdadeira invenção; por ela, a vida social e as relações entre os homens tomam uma nova forma, cuja originalidade será plenamente sentida pelos gregos (VERNANT, 2006, p. 53).

Após essa breve retomada de alguns aspectos básicos da conformação da polis grega, partiremos para a apresentação dos conceitos essenciais da política e da condição humana para Hannah Arendt, os quais serão os fundamentos para nossa discussão sobre sua relação com a educação. Ter em consideração a experiência da Antiguidade Grega para a 
compreensão dos conceitos não se trata de uma idealização desse fenômeno (ou de qualquer outra situação política iluminadora como, por exemplo, a da República Romana, a que nos referiremos ao longo da discussão deste trabalho). Tampouco representa um desejo de retorno às origens, apesar do reconhecimento de que essas experiências evidentemente assumem lugar de fundamental importância em nossa tradição enquanto tempo e espaço das primeiras experiências políticas. Portanto, tais realidades históricas apenas iluminam a reflexão de Arendt (e também a nossa) a respeito da situação de nosso mundo e de nossa existência comum.

\section{1 "A política baseia-se no fato da pluralidade humana.",}

Embora o conceito de pluralidade esteja presente em todo o pensamento de Hannah Arendt, em $O$ que é política? (obra publicada postumamente) encontramos fragmentos capazes de elucidar o que $A$ Condição Humana nos apresenta sobre seu significado para a política.

Qualquer discussão sobre política em Hannah Arendt parte da consideração sobre essa condição fundamental da existência dos homens no mundo. A pluralidade traduz-se no “[...] fato de que homens, e não o Homem, vivem na Terra e habitam o mundo" (ARENDT, 2005a, p. 15), afirmação feita em contraposição à tradição do pensamento filosófico, que pretendeu sempre, segundo Arendt (2007), compreender o homem no singular, entendido, portanto, em sua natureza e isolamento. Ela identifica nessa abordagem da tradição filosófica o seu limite de contribuição para a política, já que, sem a consciência da pluralidade humana como fenômeno do mundo, ela perde o que fundamenta sua existência, comprometendo também nossa capacidade de compreensão do que ela realmente significa.

A realidade que pode ser observada no mundo e que está ao alcance dos nossos sentidos é a da existência dos homens, em sua condição plural. É a partir dela que Arendt se dedica a pensar a política, por entender que se o homem existisse em solidão seria um deus, e a política, um absurdo. Nesse sentido, a pluralidade, fenômeno visível entre nós, se opõe à natureza humana que permanece oculta e, portanto, fora do alcance de nossa percepção. É a 
pluralidade que nos permite ver que não estamos sós: Arendt realiza, então, um pensamento sobre os homens acompanhados, e é a partir da verificação dessa condição que pensa a política.

É a pluralidade como condição da vida comum que faz com que existam tantos olhares sobre algo quanto pessoas no mundo. Cada homem oferece uma perspectiva singular sobre o que se passa fora dele, e essa diversidade gera, a partir de uma única experiência, diferentes maneiras de entendê-la. A política foi inventada como maneira de confrontar a pluralidade existente no mundo e, a partir dela, gerar algo comum. É em razão dessa variedade de perspectivas que Arendt considera que na política um fato pode ser revelado da maneira mais universal possível.

Essa pluralidade expressa também a condição singular da existência de cada homem sobre a Terra, condição esta distinta da alteridade, que é a qualidade que diferencia os seres vivos e pode ser observada entre indivíduos de uma mesma e qualquer espécie, inclusive entre os homens. A alteridade é composta das dissimilitudes entre esses elementos e se traduz em qualidades que somos capazes de descrever e nomear. Trata-se da resposta à pergunta sobre como é um indivíduo, permitindo apontar suas diferenças concretas em relação aos outros.

Em contrapartida, a singularidade é um fenômeno observado apenas entre os homens e manifesto em nossa unicidade e ineditismo: é a singularidade que revela não como é alguém, mas sim quem é. Embora não sejamos capazes de formular uma resposta a essa pergunta, expressamos quem somos através das palavras e ações que lançamos ao mundo e que permitem ao outro que nos reconheça. Portanto, a identidade de cada homem só pode ser vista e reconhecida pelos outros. Por essa razão, o nome de alguém nada nos diz sobre a pessoa se não pudemos, um dia, assistir a suas ações e ouvir suas palavras. É por essa mesma razão que somos incapazes de dizer a alguém quem somos e, quando incorremos na tentativa, terminamos por listar nossas características e qualidades, que apenas respondem o que somos.

A existência dos homens está para além da repetição da vida natural já que, no mundo que criamos e a partir dele, representamos alguém que nunca esteve aí antes. A repetição dos seres meramente naturais se dá em razão do caráter cíclico da vida: as plantas e animais repetem-se e representam apenas diferentes exemplares de uma mesma espécie. Já a existência dos homens (não a vida), segundo Arendt (2005a), assume uma forma retilínea por sermos cada um de nós um início e também iniciadores ${ }^{2}$. Assim, a singularidade se revela um

2. Cf. ARENDT, 2005a, capítulo Ação, p. 188-259. 
conceito fortemente relacionado à natalidade e à capacidade humana da ação (conceitos que veremos mais adiante).

Portanto, na ciclicidade da vida natural está contida uma repetição permanente: os seres de uma determinada espécie nascem semelhantes e cumprem suas atividades para a manutenção da vida de maneira incansável. Estes, quando morrem, estão cedendo lugar a outro indivíduo semelhante que seguirá os mesmos movimentos. Não é esse o caso dos homens, já que não somos seres apenas naturais, mas apresentamos também outra condição igualmente determinante de nossa existência: o fato de sermos mundanos. A trajetória retilínea da vida dos homens está relacionada, portanto, ao fato de sermos capazes de, com o nosso ineditismo, estabelecermos algo novo para o mundo e, com isso, compormos histórias que podem permanecer na memória de uma comunidade como parte de sua identidade. Por essa razão, a existência dos homens sobre a Terra não pode ser narrada de maneira repetitiva, afinal ela sempre apresenta um elemento novo que transforma essa narrativa.

Apesar de reconhecer a singularidade dos homens e considerá-la fundamental na sua forma de entendê-los (e de entender a própria política, já que nela os homens se revelam através de seus discursos e ações), Arendt não fundamenta seu pensamento político a partir da singularidade, mas sim da pluralidade (embora sejam entre si conceitos complementares). A razão fundamental para isso está em considerar que é pluralmente que os homens compartilham o mundo, ou seja, a pluralidade é a condição que observamos quando os homens estão reunidos, vivendo acompanhados, na presença de outros. Se a perspectiva do pensamento de Arendt fosse apenas a singularidade, ela pouco contribuiria com o rompimento da linha condutora da tradição do pensamento filosófico e político: facilmente um pensamento a partir da singularidade recairia num tipo de reflexão conduzida pelo isolamento, pela solidão. Além disso, o que se dá entre os homens - no espaço intermediário da relação estaria sendo aqui desconsiderado. Porém, quando a consciência da singularidade é observada na perspectiva da pluralidade, a discussão se abre para pensarmos o que há fora dos homens, entre eles.

No entanto, a pluralidade não deve ser entendida como a simples soma de seres singulares, mas se manifesta a partir da dinâmica das relações entre esses homens singulares. Ela se revela um fenômeno complexo, afinal os homens vivem no mundo compartilhando experiências e formando comunidades, ou seja, estabelecendo o comum a partir do diferente, intensificando ou até mesmo gerando diferenciações em relação a outros quando assim o 
fazem. Portanto, a pluralidade se manifesta no mundo e a partir dele, já que objetos, palavras e ações se interpõem entre nós e condicionam nossa identidade.

O conceito de pluralidade, para Arendt (2005a, p. 188), não desconsidera o reconhecimento da igualdade:

\begin{abstract}
A pluralidade humana [...] tem o duplo aspecto de igualdade e diferença. Se não fossem iguais, os homens seriam incapazes de compreender-se entre si e aos seus ancestrais, ou de fazer planos para o futuro e prever as necessidades das gerações vindouras. Se não fossem diferentes, se cada ser humano não diferisse de todos os que existiram, existem ou virão a existir, os homens não precisariam do discurso ou da ação para se fazerem entender.
\end{abstract}

Apesar de Arendt reconhecer uma igualdade advinda da natureza - assim como seres de uma mesma espécie possuem entre si um grau de igualdade para além da alteridade que os distingue -, a igualdade é para ela um conceito político e uma realidade que se estabelece entre os homens a partir de suas relações no mundo, e que deve ser entendida como uma experiência e um reconhecimento político. Portanto, nossa pluralidade e nossa igualdade são relativas (complementam-se enquanto realidade) e nos apresentam um paradoxo que cabe à própria política enfrentar e discutir.

O problema contido nas relações de desigualdade na política é a abertura para a imposição de uns sobre os outros, como acontece, por exemplo, no caso dos regimes tirânicos. ${ }^{3}$ A experiência da Alemanha Nazista e totalitária também ilustra o absurdo que pode significar uma ideologia que defende a suposta superioridade natural de alguns e a inferioridade de outros: com ela se impôs a violência. A igualdade e a pluralidade desapareceram do panorama político. Para Arendt, não existe política sem pluralidade, mas também não existe política sem igualdade. É a igualdade reconhecida politicamente que equipara os homens, apesar de suas diferenças, e permite aos homens plurais encontrarem-se e gerarem algo absolutamente novo provocado pela união. O poder ${ }^{4}$, que surge dessa

3 As relações políticas sustentadas pela autoridade têm a desigualdade como fator constitutivo e, embora não sejam discutidas aqui, serão consideradas em outro momento. O ensaio Que é autoridade? contido na obra Entre o Passado e o Futuro, apresenta a gênese do conceito e reflete sobre algumas das experiências políticas fundamentais sustentadas pela autoridade até seu desaparecimento no mundo moderno.

4 O significado do conceito de poder no pensamento de Hannah Arendt não é o mesmo que o usado nos discursos correntes. Para ela, "[...] poder e força não são a mesma coisa quanto à sua origem e sentido original [...]." E segue: “[...] a força é um fenômeno do indivíduo [...]” e o poder "[...] só é possível entre 
capacidade dos homens de realizarem algo juntos, só é possível a partir da igualdade.

\section{2 "A política surge entre os homens."}

\subsubsection{O mundo}

Para Arendt, "o espaço entre os homens (...) é o mundo" (ARENDT, 2008, p. 159, grifo nosso). O conceito de mundo é central para seu entendimento a respeito da política, e central também para as discussões a respeito da educação. Habitualmente, ao nos referirmos ao mundo estamos nos reportando à totalidade do planeta em que vivemos. No entanto, em $A$ Condição Humana, Arendt (2005a, p. 10) afirma: “o mundo - artifício humano - separa a existência do homem de todo ambiente meramente animal [...]”.

No contexto desse pensamento, mundo assume, então, um significado peculiar relacionado à condição artificial da existência dos homens, sendo algo inteiramente humano, constituído de elementos objetivos e intersubjetivos que interpomos entre nós. Os objetos concretos que os homens constroem - e são resultado da atividade da fabricação - nos separam do ambiente natural e condicionam nossa existência. Para compreendermos esse condicionamento e o que esses objetos representam para a identidade dos homens, basta pensarmos no que eles significam para a elaboração do conhecimento histórico e antropológico. Essas áreas do conhecimento se utilizam, dentre outras fontes, dos objetos concretos do mundo para entender a vida dos homens em determinado tempo e espaço. Tais artefatos mediavam as relações entre nós e, em grande medida, revelam a identidade daqueles que os circundavam.

Esses objetos presentes entre nós nos condicionam justamente por nos oferecerem diferentes formas de existência. As distinções entre aqueles que vivem rodeados por um contexto urbano em comparação aos que vivem a vida no campo podem nos auxiliar nessa

muitos [...]" (ARENDT, 2007, p. 79). Portanto, o poder, segundo ela, emerge do agir em conjunto.

ARENDT, 2008, p. 146, grifo nosso. 
compreensão. A presença, ou ausência, de determinados objetos que dão contorno à paisagem na qual estamos imersos (ou, ainda, dos instrumentos que são próprios a cada tipo de trabalho e que utilizamos nessas tarefas), conformam nossa identidade, já que vivemos e nos relacionamos de diferentes maneiras a partir deles.

Esses produtos da fabricação ganham significação quando nos relacionamos com eles. O condicionamento presente entre mundo e homem não é apenas a dependência que os objetos têm de que nós os fabriquemos e utilizemos. Nossa própria existência também está condicionada pelo mundo, já que a relação que estabelecemos com tais objetos - dispostos, organizados e aos quais atribuímos significados - nos permite existir como homens. Isso acontece pois o mundo, entendido como artifício humano, distingue o ambiente humano do ambiente natural ou meramente animal.

O mundo, em grande medida, é construído pelas mãos dos homens e se constitui dos resultados concretos da fabricação e que duram para além da vida individual de quem os construiu. Esses objetos servem para nós de abrigo e ganham entre nós um universo de significados intersubjetivos: é assim que deixam de ser apenas um amontoado de coisas sem sentido para, com a nossa presença, tornarem-se mundo. A partir deles podemos também nos remeter ao passado e ao futuro, já que permanecem até o presente e nos unem aos que aqui estiveram antes de nós - o que possivelmente farão com os que virão depois de nós. O mundo, então, tem a durabilidade que sustenta a história dos homens:

\footnotetext{
A objetividade do mundo - o seu caráter de coisa ou objeto - e a condição humana complementam-se uma a outra; por ser uma existência condicionada, a existência humana seria impossível sem as coisas, e estas seriam um amontoado de artigos incoerentes, um não-mundo, se esses artigos não fossem condicionantes da existência humana (ARENDT, 2005a, p. 17).
}

Embora o mundo seja composto, em grande parte, dos resultados da fabricação, ele não é constituído apenas pela concretude desses objetos, mas também por tudo que se coloca entre nós e foi assim gerado. Portanto, tudo que elaboramos de intangível e compartilhamos pode ter profundo significado mundano e condicionar também nossa existência: é este o caso das consequências imprevisíveis da ação e também do discurso.

A ação realizada por um grupo de homens tem resultados que configuram a história de 
um povo ou comunidade, oferecendo àqueles que a eles pertencem um conjunto de valores e uma identidade. A história de uma comunidade se dá pelas realizações dos homens no âmbito da ação e, a partir dela, o mundo também se configura. Portanto, “[...] o mundo do qual se fala aqui o mundo dos homens, quer dizer, o resultado do fazer humano e do agir humano, como se queira entender isso" (ARENDT, 2007, p. 37).

Toda a cultura elaborada pelos homens é parte constituinte do mundo, toda a linguagem que medeia nossas relações também. Dessa forma, os discursos - as palavras que os homens lançam ao mundo em caráter público - configuram significados compartilhados e constituem o mundo. Para compreendermos essa dimensão da ação e do discurso, podemos rememorar a história de um determinado grupo de homens, comunidade ou país. Se nos remetermos a pensar a eleição de Barack Obama à presidência dos Estados Unidos ${ }^{6}$ - a opção pelo exemplo se justifica pela atualidade da situação e relevância mundial - devemos, sem dúvida, nos lembrar das palavras e ações de Martin Luther King e dos homens que o acompanharam.

As manifestações desses homens, décadas antes, contribuíram para iniciar no país a possibilidade de uma nova realidade política, conferindo ao povo novos parâmetros de valores e pensamento que culminaram no resultado das últimas eleições americanas. Ao longo do tempo e da história de uma comunidade surgem pessoas que ousam lançar palavras para serem ouvidas publicamente e que se expõem também através de seus feitos. Essas realizações geram algo entre nós: algo que escapa da tangibilidade dos objetos resultantes da atividade da fabricação, mas que, passam à condição de realidade observável e, a nosso ver, também configuram o mundo. Assim, não apenas os livros que narram essas histórias compõem o mundo, mas também as relações entre negros e brancos nesse país se transformaram: fato que evidentemente condiciona a maneira desses homens adultos existirem, além de alterar o mundo para o qual novas crianças nascem. Assim, "o espaço entre os homens, que é o mundo, com certeza não pode existir sem homens, ao contrário de um universo sem homens ou uma natureza sem homens, seria uma contradição em si." (ARENDT, 2007, p. 36).

6 Em 4 de novembro de 2008, Barack Obama foi eleito para ocupar a presidência dos Estados Unidos da América. $\mathrm{O}$ fato de um negro assumir tal posição política nesse país é considerado especialmente marcante em razão de seu passado racista e segregador. 


\subsubsection{Esfera pública e privada}

Devido à confusão presente em nossos tempos sobre o significado e distinções entre o público e o privado, Arendt (2005a) recorre à Antiguidade Grega para compreendê-los enquanto experiência dos homens no mundo. Nós, ao sermos concebidos, recebemos a vida; e, ao nascermos, nos inserimos no mundo. Quando chegamos estamos absolutamente indefesos e sujeitos aos cuidados dos outros para que nossas necessidades sejam atendidas. A vida impõe essas necessidades e para que ela cresça e se desenvolva precisa ser resguardada. Porém, também com o nascimento chegamos ao mundo e a ele precisamos ser introduzidos para que possamos compartilhar nossa humanidade e tudo o que isso significa. Assim, enquanto a esfera privada é o lugar de dedicação às atividades relacionadas à condição humana da vida, a esfera pública é o âmbito dos homens que compartilham um mundo comum a partir de sua pluralidade e se relacionam com ele.

Embora a linha divisória entre uma esfera e outra seja difícil de ser compreendida, já que cada vez menos pode ser observada, houve épocas em que a clareza da distinção entre ambas sustentava a forma de vida de alguns homens em suas comunidades políticas. Foi o que aconteceu nas cidades gregas da Antiguidade. A esfera privada era essencialmente representada pela família. Sua justificativa era a manutenção da vida: nela seus membros dividiam tarefas, assumindo papéis distintos. Essa divisão de tarefas impunha uma desigualdade nas relações entre homem e mulher, pais e filhos - e também entre senhor e escravo. A casa era um lugar de proteção: o que se passava nesse espaço dizia respeito apenas àqueles que ali viviam, seu funcionamento se dava através de regras próprias. As necessidades impostas pela vida vigoravam no lar e determinavam as relações nele contidas.

Portanto, a própria organização familiar revela que o fato de nos reunirmos em grupos como forma de proteção e manutenção da vida aponta para o fato de sermos seres gregários (como são as abelhas e formigas), mas isso não basta para nos tornarmos seres políticos. Os homens não existem apenas para manterem suas vidas, como fazem outros animais, e dedicarem-se exclusivamente à sua manutenção. É a condição mais complexa da existência dos homens - que além da vida implica na existência do mundo e no fato de sermos plurais que justifica a separação entre esfera privada e pública (além da própria política). 
Para Arendt (2005a, p. 59), “o termo 'público’ denota dois fenômenos intimamente correlatos, mas não perfeitamente idênticos. Significa, em primeiro lugar, que tudo que vem a público pode ser visto e ouvido por todos e tem maior divulgação possível".

\footnotetext{
Em segundo lugar [...] significa o próprio mundo, na medida em que é comum a todos nós [...]. Conviver no mundo significa ter um mundo de coisas interposto entre os que nele habitam em comum, como uma mesa se interpõe entre os que se assentam ao seu redor [...]. A esfera pública, enquanto mundo comum, reúne-nos na companhia uns dos outros [...] (ARENDT, 2005a, p. 62).
}

A esfera pública supõe visibilidade e diz respeito aos assuntos da nossa existência relacionada com o mundo e com outros homens. Na Antiguidade, a existência de uma esfera que garantia as necessidades permitia a liberação para a atividade política, ou seja, para dedicação aos assuntos comuns. Enquanto na vida privada tudo era realizado entre quatro paredes, na esfera pública da polis eram apenas os muros da cidade que a limitavam, conferindo um caráter de aparição e alcance ao que era realizado ali. A diferença entre a esfera privada e a pública, para Arendt, advém do fato de que existem coisas a serem protegidas e ocultadas, enquanto existem outras que devem ser expostas e discutidas.

Aqueles que viviam dedicados apenas à vida privada - como escravos ou senhores que se ocupavam com a acumulação de riqueza e abdicavam da cidadania - estavam, no rigor do termo, privados de algo. Essa privação estava ligada à impossibilidade que tinham de revelarse aos outros através do discurso e da ação num espaço de visibilidade. Para Arendt esse caráter de exposição da singularidade - e consequente pluralidade dos homens - é fundamental ao conceito de esfera pública.

A esfera pública atribui caráter de realidade às coisas do mundo, da mesma forma que quando alguém se dá a conhecer através do discurso e da ação se torna reconhecível pelos outros. Apenas quando algo pode ser visto por um grande número de homens e assume significado compartilhado, gera algo comum. Assim, a identidade de um povo ou grupo de homens depende do que eles compartilham e reconhecem a partir da mesma linguagem e significado. Aquilo que permanece oculto e não é compartilhado ou visto por mais de um homem corre o risco de não ser considerado real (assim como o que ouve e vê um louco - por ser apenas ele - é considerado loucura e irrealidade). 
Nem tudo que é realizado aos olhos dos outros e entre os homens são atividades políticas, mas podem ser públicas. A esfera pública é o lugar da política apenas quando se dedica aos assuntos comuns através do discurso e da ação: assim, o bio politikos de Aristóteles se refere à vida política experienciada entre os cidadãos. Um possível exemplo de esfera pública, mas não-política, segundo Arendt, eram os mercados de troca da antiguidade. Neles os homens se relacionavam enquanto produtores: essa relação era mediada pelos objetos de sua fabricação. Já no espaço da ágora, os homens se apresentavam sem a mediação de objetos tangíveis e estavam ocupados em conduzir os assuntos da cidade: isso sim caracterizava a ação política e um espaço público igualmente político. Nessa esfera pública e política o que acontecia se dava sem resguardo, ou seja, em plena luz: iluminação esta oferecida pelos olhos dos outros. Nela os homens se davam a conhecer através de seus discursos àqueles que presenciavam suas palavras e, juntos, buscavam encontrar e escolher caminhos para o que dizia respeito a todos.

Embora sejam distintas, a esfera privada e a esfera pública dependem uma da outra para ganharem definição. Só existe uma esfera pública enquanto a privada se mantém para cumprir sua tarefa. Da mesma maneira, só faz sentido nos referirmos à existência de uma esfera privada se há algo que com ela não se confunda, ou seja, se houver uma outra esfera justificada por algo que não seja a própria manutenção da vida. Se os homens não fossem plurais e não vivessem cercados por um mundo, sua única condição de existência seria a vida, o que tornaria desnecessária qualquer conceitualização e distinção entre os dois âmbitos.

Apesar de termos discriminado ambas as esferas, em nossos tempos se torna cada vez mais difícil distingui-las: é como se o muro que as separasse tivesse vindo abaixo e uma adentrasse na outra, gerando algo que não se identifica mais com nenhuma delas. Isso representa, no pensamento de Arendt, a expansão da esfera social, que pode ser observada de maneira marcante a partir do início da Era Moderna. Uma forte manifestação desse fenômeno é o fato de a vida ter assumido o lugar mais digno dentre todas as nossas outras condições de existência e de nossas atividades estarem regidas pelo funcionamento do labor, ou seja, a partir da lógica da necessidade.

Desde o advento da sociedade, desde a admissão das atividades caseiras e da economia doméstica à esfera pública, a nova esfera tem-se caracterizado principalmente por uma irresistível tendência de crescer, de devorar as esferas mais 
antigas do político e do privado [...]. Este constante crescimento, cuja aceleração não menos constante podemos observar no decorrer de ao menos três séculos, é reforçado pelo fato de que, através da sociedade, o próprio processo de vida foi, de uma forma ou de outra, canalizado para a esfera pública (ARENDT, 2005a, p. 55).

Não nos dedicaremos aqui a realizar uma análise aprofundada do fenômeno de expansão da esfera social (que historicamente é longo e complexo), já que, neste momento, estamos nos dedicando a apresentar traços gerais da política e da condição humana em Hannah Arendt. Entretanto, ao longo de nossa análise sobre as relações entre a educação e a política, refletiremos sobre o que isso significa para esses dois âmbitos.

\section{3 "[...] o sentido da política é a liberdade."”}

Arendt não hesita em responder à pergunta sobre qual seria o sentido da política: a liberdade. Para tanto, ela volta mais uma vez seu olhar à polis grega e à experiência de seus cidadãos, homens livres atores da atividade política.

A liberdade vivida por esses homens tinha como condição prévia sua liberação das tarefas relacionadas ao suprimento das necessidades da vida. Somente quando deixavam de estar sob a sujeição que a manutenção da vida biológica impunha, é que passava a existir a possibilidade da experiência política da liberdade. Essa liberação era possível por tais atividades estarem delegadas a terceiros, os escravos, gerando entre os cidadãos disponibilidade para a dedicação à vida pública e aos temas da cidade.

Em A Política, Aristóteles (2007, p. 20-22) afirma: os escravos “[...] ajudam-nos com sua força física em nossas necessidades quotidianas” e, assim, “[...] existe um interesse comum e uma amizade recíproca entre o senhor e o escravo, quando é a própria natureza que os julga dignos um do outro”. Portanto, na Antiguidade Grega, tal liberação acontecia por meio da presença de escravos, que se dedicavam às atividades de manutenção da vida, sendo

\footnotetext{
ARENDT, 2007, p. 38, grifo nosso.
} 
que a relação entre eles e seus senhores se pautava numa utilidade de dupla mão: uns supriam a vida e os outros, com seus iguais, cuidavam dos temas comuns da cidade.

Eram escravos na Grécia Antiga aqueles que estavam destituídos da condição de cidadãos e trabalhavam para garantir a subsistência ou a materialidade da cidade. Embora esse seja um tema particularmente polêmico e complexo, Arendt atenta para a liberdade vivida pelos cidadãos entre si na polis: seu interesse, portanto, se dava pela liberdade enquanto fenômeno tangível e experienciado na praça pública.

Apesar de a liberação da necessidade ser condição prévia para a cidadania, ela não bastava para que esses homens fossem livres: tal liberdade só se configurava como realidade quando ocorria o encontro dos iguais na praça pública. A liberdade estava intimamente relacionada à igualdade presente entre eles e também à condição desse encontro. Como vimos, relações desiguais abrem possibilidade para a dominação, que é o oposto da liberdade. Se há dominação, há sujeição e os homens imersos nessa relação deixam de ser livres, independentemente do lugar que assumem - de dominadores ou dominados. Segundo Arendt, isso nada tem a ver com política e, portanto, o fato de o encontro entre cidadãos na ágora acontecer entre iguais era o que permitia a experiência da liberdade entre eles.

\begin{abstract}
A coisa política entendida nesse sentido grego está, portanto, centrada em torno da liberdade, sendo liberdade entendida negativamente como o não-ser-dominado e não dominar, e positivamente como um espaço que só pode ser produzido por muitos, onde cada qual se move entre iguais. Sem esses outros que são meus iguais não existe liberdade alguma e por isso aquele que domina outros e, por conseguinte, é diferente dos outros em princípio, é mais feliz e digno de inveja que aqueles a quem ele domina, mas não é mais livre em coisa nenhuma. Ele também se move num espaço no qual a liberdade não existe, em absoluto. Isso é difícil nós compreendermos porque vinculamos à igualdade o conceito de justiça e não o de liberdade $[\ldots]^{8}$ (ARENDT, 2007, p. 48).
\end{abstract}

A igualdade surge aqui como condição para a liberdade que existe a partir dessa relação e que passa a ser entendida como uma categoria política - algo que pode gerar certo estranhamento tendo em conta o significado que ela assumiu ao longo da tradição do

8 Não apenas quem é dominado sofre de privação de liberdade, mas também aquele que domina, já que perde sua condição de igualdade. A ele resta a força - capacidade individual -, e não o poder - que surge apenas com a união dos homens. 
pensamento. É em Que é liberdade? que Arendt (2005b) percorre a tradição do pensamento filosófico para compreender como tal conceito vem sendo entendido, além de apresentá-lo segundo uma perspectiva política.

Nesse texto, Arendt não só apresenta a experiência da liberdade política da Grécia préfilosófica, mas também narra e analisa as transformações desse conceito ao longo da história do pensamento ocidental, que deslocou suas manifestações da esfera entre os homens para dentro deles. No caso da filosofia grega, essa compreensão de liberdade surge, por exemplo, no isolamento do filósofo que se retira do mundo para vivê-la. No final da Antiguidade, Epicteto a define como a condição de ser livre dos próprios desejos, o que mais tarde será assimilado pelo cristianismo, afirmando a oposição entre paixão e vontade (e a liberdade como sendo sua principal faculdade). Ao longo da tradição filosófica a liberdade se transforma numa condição da vida interior de todo e qualquer homem. Portanto, foi um conceito de liberdade deslocado de sua aparição como fenômeno político o que vigorou na história do pensamento filosófico ocidental. E, a partir da conversão de Paulo ao cristianismo, sua noção passa também a ser confundida com a do livre-arbítrio.

Arendt segue em sua análise e reflete também sobre alguns conceitos de liberdade presentes na teoria política. Menciona os pensadores dos séculos XVII e XVIII que, segundo ela, identificavam, em sua maioria, liberdade com segurança: entendida, então, como finalidade da política. Mas é com o pensamento dos séculos XIX e XX - com a ascensão das Ciências Sociais e Políticas - que seu sentido original (vinculado à experiência política) se perde ainda mais. Quando a política passa a ser concebida, a partir do início da Idade Moderna, como a instância de proteção do que diz respeito à vida individual, a liberdade perde todo seu sentido político por ser concebida unida à necessidade (sendo, na realidade, seu oposto). Todo esse processo culmina com o liberalismo, que considera a liberdade algo a ser assegurado pela política de maneira invertida à sua acepção original: devendo garantir a segurança individual para que a liberdade possa existir - entendida como a possibilidade de levar a própria vida a partir da liberação da política, a ela não tendo que se dedicar.

Embora o que apresentamos aqui sobre o conceito de liberdade ao longo da filosofia seja apenas a denúncia de uma inversão de sentido, notamos que dele foi retirada sua implicação política e pública, propriamente dita. Enquanto na polis a liberdade estava relacionada a um espaço comum e de aparição, ao longo da tradição ela tornou-se uma condição individual e oculta. A liberdade nas cidades gregas era um fenômeno experienciado 
e aparente: a união dos cidadãos era capaz de gerar sempre algo novo e imprevisto, união advinda da igualdade. Sua visibilidade a configurava como fenômeno do âmbito público e identificava-se, para Arendt (2005a), com dois termos gregos experienciados na política: archein e prattein. Archein era a capacidade de começar algo, iniciar, e prattein, a capacidade de colocar algo em andamento. Nesse sentido, liberdade e ação são idênticas, o que adiante apresentaremos mais detidamente. É nesse significado de liberdade que Arendt encontra o que considera ser o sentido da política.

O desvelamento de seu sentido fez com que Arendt considerasse o totalismo o pior dos regimes já concretizados na história, justamente por ter pretendido retirar dos homens sua capacidade de ação e rendê-los a um caminho histórico pré-definido. Por conseguinte, o totalitarismo elimina o sentido e fundamento da política: faz desaparecer a liberdade e pretende retirar do mundo a pluralidade dos homens por meio do uso da violência e do temor. A violência que cala e a prática do extermínio fazem desaparecer do mundo homens singulares e suas manifestações. Aqueles que sobrevivem veem-se impedidos de começar algo novo e de agir para interromper o curso automático dos fatos, imposto pela ordem social. $\mathrm{O}$ totalitarismo, a Segunda Guerra Mundial e as bombas atômicas apresentaram-se realidades tão monstruosas que delas surgiu uma profunda desconfiança em relação à própria política: é como se os homens só pudessem passar a ser livres quando ela chegasse ao fim.

Para identificarmos liberdade à capacidade de começar algo novo nos reportaremos ao conceito de ação, afinal Arendt (2005b, p. 199) afirma que "[...] ser livre e agir são uma mesma coisa". Mas para chegarmos a isso será necessário anteriormente distinguirmos a ação das outras atividades humanas.

\subsection{As atividades humanas}

Em A Condição Humana, Arendt (2005a, p. 31) se dedica a pensar sobre a vita activa, ou seja: “[...] a vida humana na medida em que se empenha ativamente em fazer algo". São três as categorias de atividades desempenhadas pelos homens na vita activa: o labor, a 
fabricação e a ação ${ }^{9}$. Elas são referência para toda a sua reflexão sobre a condição humana e, nesse sentido, é importante compreendê-las bem e distintamente (o que nos permitirá chegar às formas de realização da política).

\subsubsection{Labor}

O labor é - dentre as três atividades da vita activa - toda e qualquer atividade voltada para a manutenção da vida humana e, portanto, movida e marcada pela necessidade. Assim, "A condição humana do labor é a própria vida" (ARENDT, 2005a, p. 15). Por estar relacionado ao ciclo vital, seu funcionamento se dá a partir da lógica que rege qualquer outra espécie de vida, sendo a atividade que mais nos aproxima dos outros animais. O labor realiza-

9 Na tradução da obra The Human Condition realizada por Roberto Raposo para o português encontramos as três atividades humanas: o labor (labor), o trabalho (work) e a ação (action). No entanto, essa denominação para as três atividades tem sido atualmente questionada e outras soluções têm sido propostas na tentativa de delimitar mais precisamente os conceitos. Adriano Correia, um dos principais estudiosos da obra de Arendt no Brasil e que retraduziu a obra em questão (tradução ainda não publicada), utiliza outros termos para tais atividades, a saber: trabalho (labor), fabricação ou obra (work) e ação (action). Encontramos sua justificativa para essa alteração na nota 1 de seu texto Trabalho, obra e ação:

“Ao optar por 'Trabalho, obra, ação', seguimos as próprias indicações de Arendt, tanto no próprio texto traduzido quanto em notas a $A$ Condição Humana (HC). Na nota 3, à p. 80 (cf. trad. bras.), na seção intitulada 'The labour of our body and the work of our hands', Arendt afirma o seguinte: 'Assim, a língua grega distingue entre ponein e ergazesthai, o latim entre laborare e facere ou fabricare, que têm a mesma raiz etimológica, o francês entre travailler e ouvrer, o alemão entre arbeiten e werken. Em todos estes casos, apenas os equivalentes de 'labor' têm uma conotação inequívoca de dores e penas. O alemão Arbeit se aplicava originalmente apenas ao trabalho agrícola executado por servos e não à obra do artesão, que era chamada Werk. O francês travailler substituiu o mais antigo labourer e deriva de tripalium, uma espécie de tortura (ver Grimm, Wörterbuch, p. 1854ss., e Lucien Fèbre, 'Travail: évolution d'un mot et d'une idée', Journal de psychologie normale et pathologique, vol. XLI, $\left.\mathrm{n}^{\circ} 1,1948\right)$ '. Cf. Hannah ARENDT, The human condition (HC), p. 79-84 (cf. p. 90-95). A despeito de Hannah Arendt não mencionar o português, o que se aplica ao francês, etimologicamente, também se ajusta ao nosso idioma. Cf., a este respeito, Antenor NASCENTES, Dicionário etimológico da língua portuguesa. Rio de Janeiro, 1955; José Pedro MACHADO, Dicionário etimológico da língua portuguesa. v. II. Lisboa: Confluência, 1959; e Antonio Geraldo CUNHA, Dicionário etimológico Nova Fronteira. 2. ed. São Paulo: Nova Fronteira [s.d.]”.

No entanto, neste trabalho utilizaremos o termo labor (para labor, conforme a proposta de Raposo), fabricação (para work, conforme a proposta de Correia) e ação (para action, termo que ambos utilizam). A razão para a aceitação do termo fabricação se dá pelo fato de considerarmos que ele realmente expressa melhor o conceito que define. Já a opção pela manutenção do termo labor apresenta algumas justificativas. A primeira delas se dá pelo fato de que, embora a etimologia revele distinções, na língua portuguesa contemporânea labor é entendido como sinônimo de trabalho (vide Houaiss, Aurélio), não provocando grande diferença o uso de um ou outro para expressar o conceito. A segunda razão da escolha está relacionada à anterior. Em virtude de considerarmos que a alteração não contribui significativamente para a delimitação do conceito, optamos por manter o primeiro, já que está consagrado pelo uso. Consideramos que trocar labor por trabalho pode gerar confusões para o leitor, pois o termo trabalho, nas obras até então traduzidas, faz referência a outra das atividades humanas. 
se pela imperiosa necessidade de nos mantermos vivos: advém da relação do homem com a vida, inserindo-o na lógica da natureza. Por essa razão, essa atividade nada diferencia os homens entre si ou de qualquer ser vivo.

As necessidades que a vida impõe foram consideradas por muitas comunidades, ao longo da história, um fardo a ser carregado pelo homem. Vimos que, na Grécia Antiga, a liberação das atividades do labor pelos cidadãos acontecia por meio da dedicação dos escravos a essas tarefas e, em tempos mais recentes, sonhou-se que tal liberação pudesse advir da divisão do trabalho ou do desenvolvimento da automação. No entanto, com a modernidade, o que aconteceu, desapercebidamente, foi o exato oposto: a vida foi elevada à categoria de mais alto bem e nossa relação com as outras atividades humanas passou a ser regida pela marca da necessidade.

Para Arendt (2005a), a liberação do labor não pode e não deve ser total ${ }^{10}$. Não pode porque, se não nos dedicarmos ao labor, interrompemos a vida. E não deve porque com o labor experimentamos a satisfação advinda da própria vida: tão real quanto o desfrute que vivemos a partir de um corpo sadio. Fazendo referência à satisfação gerada pelo labor, Arendt (2005a, p. 120) afirma:

\footnotetext{
A bênção do labor consiste no fato de que o esforço e a recompensa seguem-se tão de perto quanto a produção e o consumo dos meios de subsistência, de modo que a felicidade é concomitante com o próprio processo [...]. O direito de buscar esta felicidade é realmente tão inegável quanto o direito à vida: chega a ser idêntico a ela $[\ldots]$.
}

Nessa afirmação identifica-se a felicidade advinda como recompensa dessas atividades (ou seja, a manutenção da vida, que é a finalidade do labor) com o próprio processo e esforço pela busca da satisfação da necessidade (o meio pelo qual se conquista seu fim). Portanto, se quisermos pensar numa relação entre meios e fins para o labor, encontraremos dificuldade em distinguir cada uma dessas etapas, já que seu processo e sua finalidade na maioria das vezes misturam-se, numa forma cíclica e interminável. Laborar já é, em si, suprir as necessidades, já que seus resultados se misturam ao processo: assim como respirar é, em si, manter-se vivo. A condição de necessidade - que é constante e que começa e

10 Cf. ARENDT, 2007, capítulo Labor, p. 90-148. 
termina de maneira ininterrupta - confere ao labor um caráter cíclico, assim como a própria vida está imersa num ciclo natural.

Essa íntima relação entre meios e fins no labor explica a efemeridade de seus produtos. Quando o labor gera algum tipo de produto, este é apenas temporário, pois está destinado única e exclusivamente ao consumo ou ao breve desaparecimento. O ciclo da vida biológica “[...] é sustentado pelo consumo, e a atividade que provê os meios de consumo é o labor" (ARENDT, 2005a, p. 110). Assim, toda a dedicação que supõe, por exemplo, a preparação de um pão em todas as suas etapas, desaparece do mundo num curto intervalo de tempo através de seu consumo, que é seu destino.

A partir da reflexão sobre o consumo podemos revelar o paradoxo contido no labor. Consumir significa corroer até a destruição, absorver, esgotar, aniquilar ${ }^{11}$. Portanto, ao mesmo tempo em que é a vida que justifica o labor, a destruição e a morte estão contidas nele - algo que se dá pelo simples fato de a vida e de a morte serem etapas de um mesmo ciclo. Para que a vida se mantenha precisamos consumir os produtos do labor, e o consumo nada mais é do que a destruição; afinal, ele faz com que aquilo que é consumido desapareça para que possa se mesclar a nós e nos fazer subsistir. Da mesma maneira, a morte de um elemento vivo é necessária para a vida de outros: assim se dá o equilíbrio no conjunto da natureza, permitindo a sobrevivência de alguns e o espaço necessário para o nascimento de outros. Compreender o papel central do consumo para a atividade do labor é fundamental para que possamos diferenciar as três atividades humanas da vita activa entre si.

Os resultados da atividade do labor - em comparação aos obtidos pela fabricação - são

[...] mais naturais. Embora feitas pelo homem, vêm e vão, são produzidas e consumidas de acordo com o eterno movimento cíclico da natureza. Cíclico, também, é o movimento do organismo vivo, sem exclusão do corpo humano, enquanto ele pode suportar o processo que permeia o seu ser e o torna vivo (ARENDT, 2005a, p.107).

O fato de a realização do labor gerar ou não gerar produtos fica mais evidente quando comparamos, por exemplo, a atividade já citada de fazer um pão - da plantação do trigo ao cozimento da massa - à atividade de colher um fruto disponível em uma árvore que não foi

11 Segundo o Dicionário Aurélio Eletrônico, 2004. 
cultivada por ninguém. Ambas são atividades que tem como finalidade saciar a fome, mas ao mesmo tempo são bastante distintas em relação ao seu processo: colher um fruto não supõe as várias etapas que estão presentes na produção de um pão, nem requer tanto esforço. Porém, é importante notarmos que tanto o pão quanto o fruto são quase que imediatamente consumidos na mesma velocidade para que cumpram o destino da manutenção da vida.

Se os produtos do labor não forem consumidos rapidamente, perecem por si mesmos, pois só existem numa condição de breve permanência. Eles estão destinados a entrar novamente no ciclo vital, sendo absorvidos novamente pela vida - e até mesmo a decomposição representa esse retorno. O produto do labor "[...] retorna ao círculo global e gigantesco da própria natureza, onde não existe começo nem fim e onde todas as coisas naturais circulam em imutável, infindável repetição.” (ARENDT, 2005a, p. 108). Por isso, tudo o que se produz para a manutenção da vida é menos durável que os produtos da fabricação, justamente porque sua única função é a de desaparecer através do consumo para que a vida seja assegurada. A existência fugaz e transitória é característica essencial de tudo aquilo que serve para atender à necessidade.

Tanto a necessidade quanto o consumo são cíclicos: sem início ou fim determináveis e inseridos num processo biológico natural. Toda vez que alguma atividade do labor termina, deve começar novamente. Esse é um fato que não se dá apenas na perspectiva da vida de um único indivíduo de uma determinada espécie - como, por exemplo, no caso de um macaco que precisa caçar incessantemente ao longo da vida -, mas também numa perspectiva coletiva - assim como essa mesma espécie de macacos precisa reproduzir-se repetidas vezes para que não desapareça definitivamente.

O labor, por ser a atividade que mantém a vida, é a primeira das atividades humanas, afinal é a mais básica e a única absolutamente necessária. Através dele os homens se mantêm vivos e integrados à vida conjunta do planeta: com o labor asseguramos não só a vida do indivíduo, mas também a continuidade de nossa existência enquanto espécie. Para isso, tudo que o corpo realiza para sua própria manutenção precisa seguir seu curso de forma repetida e contínua. Portanto, o labor não desaparece da Terra com a morte de um único homem: continua sempre em seu caráter de necessidade, num ciclo inesgotável. A fertilidade entendida como o ato de gerar novos indivíduos - é labor e se dá na repetição de processos. Mais tarde, porém, trataremos de refletir sobre as implicações do nascimento de homens ao mundo, distintamente da situação que gera o nascimento em outras espécies vivas. 


\subsubsection{Fabricação}

Enquanto as atividades do labor atendem à manutenção da vida e resultam em produtos efêmeros, a fabricação organiza e constrói a morada do homem sobre a Terra, gerando, assim, a artificialidade que nos envolve e que aqui chamamos de mundo. Assim, "A condição humana do trabalho ${ }^{12}$ é a mundanidade" (ARENDT, 2005a, p. 15), e tudo aquilo que construímos a partir dessa atividade nos serve de abrigo e instrumento, configurando um ambiente humano. É a condição de durabilidade dos artefatos fabricados pelo homem que permite a constituição do mundo. Embora essa permanência não seja absoluta, afinal tais objetos são construídos por mãos mortais, seu tempo de duração pode ser maior do que a vida de um único homem, fazendo com que sirvam de elo entre as diferentes gerações.

Enquanto consumimos aquilo que o labor produz, usamos aquilo que resulta da fabricação. Apesar de duráveis, tais resultados evidentemente se desgastam, e, mesmo se esses objetos se mantiverem sem uso, o próprio tempo fará com que pereçam e retornem ao ciclo da vida, incorporando-se à natureza novamente. Porém, a destruição dos bens gerados pela fabricação são acidentais, diferentemente do caso do desaparecimento quase imediato dos produtos do labor. Assim, “[...] se abandonada a si mesma ou descartada do mundo humano a cadeira voltará a ser lenha, e a lenha perecerá e retornará ao solo de onde surgiu a árvore que foi cortada para transformar-se no material sobre o qual se trabalhou e sobre o qual se construiu" (ARENDT, 2005a, p. 150).

É com o ir e vir das gerações que os objetos resultantes da fabricação se vão do mundo humano: porém, enquanto permanecem, nos conferem identidade - materialidade que nos condiciona. Seu tempo de permanência oferece estabilidade à vida humana e, assim, as condições da existência dos homens, sujeitas ao constante movimento que a vida biológica impõe, se alteram: o ritmo acelerado e natural da destruição e do labor advindo da natureza se transforma pela artificialidade que criamos com os objetos da fabricação.

12 Sempre que as citações de A Condição Humana se referirem à atividade do trabalho, este termo significará o mesmo que fabricação. 
Em outras palavras, contra a subjetividade dos homens ergue-se a objetividade do mundo feito pelo homem, e não a sublime indiferença de uma natureza intacta, cuja devastadora força elementar os forçaria a percorrer inexoravelmente o círculo do seu próprio movimento biológico, em harmonia com o movimento cíclico maior do reino da natureza. [...] Sem um mundo interposto entre os homens e a natureza, haveria eterno movimento, mas não objetividade (ARENDT, 2005a, p. 150).

A fabricação, então, se traduz em toda atividade voltada para a construção de um mundo de objetos tangíveis e, portanto, a reificação é parte constituinte desse processo por culminar num produto concreto e objetivo. A atividade de fabricar geralmente se caracteriza também pela multiplicação: a partir de um modelo - que pode ser uma imagem mental ou observada -, o primeiro de muitos objetos é fabricado, para depois ser repetido. Construir objetos concretos é tarefa do homo faber, e a fabricação, sua atividade mais marcante.

Arendt (2005a) qualifica alguns objetos como sendo mais ou menos mundanos que outros a partir de seu maior ou menor tempo de permanência no mundo ${ }^{13}$. Os que ela considera mais mundanos são os de maior durabilidade e que constituem o mundo de forma mais permanente. Consequentemente, os menos mundanos são aqueles que apresentam menor duração e que estão mais sujeitos à degradação e à destruição. Assim, as obras de arte são entendidas por Arendt como sendo os objetos mais mundanos dentre todos. O valor compartilhado e reconhecido que assumem de geração a geração revela seu significado para o mundo e para a identidade de diferentes comunidades, mesmo não sendo objetos regidos pela utilidade.

Durante a atividade de construir o mundo, o homem assume o lugar de amo e senhor da natureza: emprega sua força retirando dela seus recursos e utilizando-os como materiais a serem modificados até que a tarefa da fabricação esteja concluída. Assim, a fabricação apresenta um caráter de violência do ponto de vista da natureza. Portanto, tanto a atividade da fabricação quanto a atividade do labor contêm em si um elemento de destruição. No entanto, é importante distinguirmos como essa condição se dá em cada uma dessas atividades:

É verdade que este aspecto destrutivo e devorador da atividade do labor só é visível do ponto de vista do mundo e em oposição ao trabalho, que não prepara a matéria para incorporá-la, mas transforma-a em material a ser trabalhado e utilizado como

13 Cf. ARENDT, 2005a, capítulo Trabalho, p. 149-187. 
produto final. Do ponto de vista da natureza, o trabalho, e não o labor, é destrutivo uma vez que o processo de trabalhar subtrai material da natureza sem o devolver no curso rápido do metabolismo natural do organismo vivo (ARENDT, 2005a, p. 112).

Sendo assim, o labor é destrutivo do ponto de vista do mundo (já que o que se destrói através dele rapidamente retorna ao curso da vida), enquanto a fabricação é destrutiva do ponto de vista da natureza (como interromper a vida de uma árvore para utilizar-se de sua madeira para a confecção de uma mesa). Quando os homens interrompem o ciclo da natureza para a confecção de um objeto de uso, não estão sujeitos à necessidade, mas agem como senhores desse processo e colocam-se acima da natureza, sentindo-se capazes de controlá-la. Assim, a violência da fabricação sobre a natureza se traduz na interrupção do ciclo natural, estabelecendo um processo com um começo e um fim previsível e delimitado.

Para Arendt, essa atitude frente à natureza deve ter limites para que não pensemos que tudo podemos destruir e instrumentalizar. Embora a fabricação seja uma atividade própria do homem, tem-se mostrado indesejável que estabeleçamos uma relação com a natureza como se todos os seus recursos estivessem à nossa disposição e fossem meios para os inúmeros fins que possamos estabelecer. Se assim for, entenderemos que tudo o que existe pode ser considerado meramente um objeto de uso destinado apenas a nos servir: será como se passássemos a ser a medida de todas as coisas existentes, como se nada devesse existir sem o propósito de nos atender.

Na fabricação o fim ordena os meios. Porém, do ponto de vista do mundo, os objetos da fabricação não são fins em si mesmos, pois, enquanto são usados, tornam-se meio para algo, apresentando-se como fins de curta duração e retornando sempre à posição de meios. Portanto, somos capazes de distinguir claramente quando um objeto assume lugar de fim ou quando ele está disposto como meio, na mesma medida em que somos capazes de distinguir o processo da fabricação de seu produto. Assim, numa fábrica de tesouras ela é considerada produto e, portanto, o fim alcançado pelo processo. Entretanto, nas mãos de uma costureira, ela se tornará apenas um meio para outros fins. Da mesma maneira, as roupas que para ela são fins se tornarão meios ao serem vestidas.

Arendt desenvolve uma análise crítica sobre a situação da sociedade de consumo no capitalismo, o que discutiremos mais tarde neste trabalho. Na medida em que consumimos os objetos da fabricação descartando-os e retirando deles sua condição de durabilidade e, por 
consequência, de elemento estabilizador da existência humana no mundo, a fabricação passa a ordenar-se pelas regras e condições que regem o labor. A fabricação, assim, se descaracteriza e, junto com ela, a condição dos homens se transforma, pois o próprio mundo fica ameaçado. Com isso, o ciclo da vida, que se move por automatismos que conduzem necessariamente à destruição, se impõe. Assim, nós homens perdemos a capacidade de, através da fabricação, transcender as necessidades da vida; e essa atividade deixa de cumprir com sua finalidade de construção do mundo que nos condiciona, nos oferece segurança e identidade.

\subsubsection{Ação e discurso ${ }^{14}$}

Enfim, apresentaremos as atividades que realizam a política: afinal, a condição humana da ação e do discurso é a pluralidade. Para compreendermos essa afirmação retornaremos mais uma vez, num primeiro momento, à polis grega, buscando encontrar o lugar e a importância da palavra nesse contexto. "O que implica o sistema da polis é primeiramente uma extraordinária preeminência da palavra sobre todos os outros mecanismos de poder" (VERNANT, 2006, p. 53-54).

A invenção da política significou o surgimento de uma nova forma de tratar e oferecer solução para os assuntos comuns. Até então, a condução das comunidades gregas estava centralizada na figura de um único homem. É através do uso livre e igualitário da palavra na praça pública que a polis se tornou uma invenção: nela se estabeleceu a mediação do discurso proferido por diferentes homens como um instrumento de condução dos assuntos comuns, forma até então inédita (na história que conhecemos) de os homens fazerem uso de sua particular capacidade da linguagem. Aristóteles (2007, p. 16) se refere a essa capacidade ao justificar o fato de os homens se dedicarem à política: "Dizemos que a natureza não faz nada em vão. Somente o homem, dentre todos os animais tem o dom da palavra [...]”.

Na praça pública os cidadãos se reuniam: de igual para igual emitiam opiniões e ideias a serem confrontadas com a fala de outros. A prática de falar, ouvir e falar novamente

14 Em A Condição Humana estão apresentadas as três atividades humanas: labor, trabalho e ação. Porém, neste trabalho, optamos por apresentá-las unidas no título do subcapítulo que se refere às atividades políticas: a ação $e$ o discurso. As razões da escolha serão esclarecidas no decorrer do próprio texto. 
conformava a ação política na ágora e mediava a condução dos temas públicos num espaço igualmente público. O discurso era proferido com a intenção de persuadir os demais sobre a resolução a ser oferecida à questão em pauta. Na polis a palavra não era utilizada apenas para comunicar algo, mas sim para gerar o novo e imprevisto entre os homens. Assim, a palavra

[...] torna-se o instrumento político por excelência, a chave de toda autoridade no

Estado [...]. Esse poder da palavra - de que os gregos farão uma divindade: Peithó, a força da persuasão - lembra a eficácia das palavras e das fórmulas em certos rituais religiosos, ou o valor atribuído aos 'ditos' do rei quando pronuncia soberanamente a themis; entretanto, trata-se na realidade de coisa bem diferente. A palavra não é mais o termo ritual, a fórmula justa, mas o debate contraditório, a discussão, a argumentação. Supõe um público ao qual ela se dirige [...] (VERNANT, 2006, p. 5354).

Apenas a presença de vários homens justificava o debate: seu sentido advinha da pluralidade e das diferentes formas de cada cidadão observar um fenômeno e ter algo a dizer a seu respeito. A praça pública era, portanto, o espaço por excelência da manifestação da condição plural dos homens através de seus discursos. Em vez de a palavra ser instrumento exclusivo de um único homem soberano - aquele que ordena e se coloca hierarquicamente acima dos outros -, passa a ser possibilidade a todos e forma de partilha de ideias. Criava-se, com isso, um espaço de aparição, de visibilidade. Nele ficavam expostos tanto os assuntos que diziam respeito à comunidade quanto os homens que ali estavam, conformando uma esfera pública e política.

Nesse espaço a imposição da força de uma única autoridade cede lugar à igualdade e à persuasão. O cetro - que era o objeto carregado pelo ánax, autoridade das comunidades gregas anteriores - passa a circular entre todos e a trocar de mãos. Quando um cidadão queria a palavra, tomava o cetro e a proferia. Mas no momento seguinte era outro que assumia o lugar central da ágora e então ele, com o cetro nas mãos, se manifestava aos olhos de seus iguais. Assim, a própria atividade política estabelecia a igualdade entre os cidadãos quando desaparecia entre eles a força e a dominação para dar lugar ao uso da palavra. Essa igualdade permitia a revelação da pluralidade dos homens e, com ela, a singularidade se tornava manifesta: o discurso permitia a expressão de quem era cada um deles. O resultado do confronto dessa diversidade gerava algo que não estava contido apenas nas palavras de um 
único homem. Portanto, na praça pública, quando se reuniam os cidadãos, estava presente a possibilidade constante de algo absolutamente novo e inesperado compor-se entre eles.

Esclarecido o papel do discurso, nos resta compreender em que medida ele se identifica e se distingue da ação. Ao referir-se à invenção da polis, Arendt (2005a, p. 210) afirma:

\footnotetext{
Não nos interessam aqui as causas históricas do surgimento da cidade-estado grega [...]. Ao acreditarmos nas célebres palavras de Péricles na oração fúnebre, a polis era uma garantia aos que haviam convertido mares e terras no cenário do seu destemor de que não ficariam sem testemunho e não dependeriam do louvor de Homero nem de outro artista da palavra; sem a ajuda de terceiros, os que agiam podiam estabelecer, juntos, a memória eterna de suas ações, boas ou más, e de inspirar a admiração dos contemporâneos e da posteridade. Em outras palavras, a convivência dos homens sob a forma de polis parecia garantir a imperecibilidade das mais fúteis atividades humanas - a ação e o discurso - e dos menos tangíveis e mais efêmeros 'produtos' do homem - os feitos e as histórias que deles resultam.
}

Arendt encontra nas palavras de Péricles outra razão para a invenção da polis, além de seu contexto histórico, relacionada ao temperamento grego. As narrativas de Homero foram a maneira encontrada pelos gregos de perpetuar as ações de um determinado grupo de homens corajosos, capazes de se afastarem de suas casas para realizar feitos que marcariam sua identidade comum. A solução encontrada para fazer com que feitos como esses, grandes e extraordinários, passassem a ser possibilidade viva entre eles foi a invenção da polis. A intenção era a de criar um espaço para que fossem constantemente possíveis novos feitos que marcassem a história grega: para que pudessem, juntos, realizar algo grandioso. Nesse sentido, os feitos desses homens poderiam ser extraordinários por serem especiais, mas não mais por serem raras as possibilidades de sua realização: sua possibilidade estava presente sempre que os homens se reuniam na ágora, onde a coragem que tinham que assumir era a da exposição pública e do envolvimento em temas que consideravam serem os mais nobres.

A possibilidade da ação - do novo que pode ser narrado e constituir a história desses povos - é, nesse sentido, a justificativa para a invenção da política. Estava presente neles o desejo de permanecer - de tornarem-se imortais - através da narrativa posterior de seus feitos. Na polis o discurso era a forma de a ação política realizar-se. Com isso, a ação pelo discurso 
foi elevada à categoria de atividade mais humana e mais nobre. O discurso era ação política na medida em que realizava e gerava algo absolutamente novo: o ato de compartilhar uma perspectiva através do discurso possibilitava o surgimento do inesperado. Assim, o inédito, que era cada homem em sua singularidade, se manifestava aos olhos e ouvidos públicos.

Em A Condição Humana, Arendt (2005a) apresenta três atividades humanas: o labor, a fabricação e a ação. Porém, as atividades da ação e do discurso estão contidas uma na outra, pois ambas permitem que os outros nos conheçam, além de serem formas de realização da política. Portanto, elas não podem estar dissociadas. Isso porque o discurso, desprovido da ação, incorre no perigo de perder sua capacidade de dar início a algo; já a ação, desprovida do discurso, padece de sua capacidade de revelação e facilmente se tornaria incompreensível. Quem age e não anuncia o que está por fazer, ou o que já fez, perde a oportunidade de oferecer aos outros o pensamento que o acompanha e os princípios que o moveram. Nem o labor nem a fabricação precisam de um discurso que os revele e lhes ofereça sentido, mas a ação, sim.

Se existe relação tão estreita entre ação e discurso é que o ato primordial e especificamente humano deve, ao mesmo tempo, conter a resposta à pergunta que se faz a todo recém-chegado: 'Quem és?'. Esta revelação de quem alguém é está implícita tanto em suas palavras quando em seus atos; contudo, a afinidade entre discurso e revelação é, obviamente, muito maior que a afinidade entre ação e revelação, tal como a afinidade entre ação e início é maior que a afinidade entre discurso e início, embora grande parte, senão a maioria, dos atos assuma forma de discurso (ARENDT, 2005a, p. 191).

Assim, se o discurso está mais relacionado à revelação, a ação, na medida em que também revela, está intimamente relacionada à atualização da singularidade, ou seja, à capacidade de nos tornarmos presentes no mundo através de nossos atos. Esses atos são a reafirmação de nossa existência singular e, portanto, a ação advém do fato de termos nascido. A renovação do mundo possível pela ação

[...] decorre do começo que vem ao mundo quando nascemos, e ao qual respondemos começando algo novo por nossa própria iniciativa. [...] Por constituírem um initium, por serem recém-chegados e iniciadores em virtude do fato 
de terem nascido, os homens tomam iniciativas, são impelidos a agir. [A natalidade é] [...] um início [...] de alguém que é ele próprio, um iniciador. Com a criação do homem, veio ao mundo o próprio preceito de início (ARENDT, 2005a, p.189-190).

Cada homem é em si um início por seu ineditismo e sua capacidade de agir. Ao apresentarmos a atividade do labor mencionamos que a vida natural assume a forma de funcionamento cíclico por se realizar pela repetição. No entanto, a existência dos homens sobre a Terra, entendidos como seres mundanos, apresenta-se retilínea em razão da singularidade, o que significa que cada um de nós é único e irrepetível, representando, portanto, um novo começo. É o fato de existirem inícios que faz com que existam histórias a serem narradas. Com a chegada de homens ao mundo, ou seja, através do nascimento humano, o início sempre se restabelece - e se mantém como possibilidade de atualização ao longo da vida através de nossa capacidade de ação. Nossas ações, realizadas em conjunto, geram uma história comum: e esta pode ser sempre renovada. Nesse sentido, os homens são atores (já que agem) e autores (por suas palavras) de seus atos.

Apesar da liberdade contida na ação, nenhum homem é autor absoluto de toda a sua existência, já que vivemos imersos numa teia de relações, de forma que nossas ações alteram as histórias dos outros, bem como as ações dos outros atuam sobre nossa história. Dessa forma, a ação produz resultados imprevisíveis: nunca se sabe como ou quando suas consequências terão fim. Mais uma vez podemos nos remeter ao exemplo de Martin Luther King: o alcance de suas ações não poderia nunca ser previsto. E mesmo quando observamos hoje a recente eleição de Obama à presidência dos EUA podemos dizer que aquela ação anterior obteve aí seu auge, mas não podemos afirmar que suas consequências tenham chegado a seu fim: a ação, portanto, é ilimitada. Hoje, de forma retrospectiva, podemos identificar nesse exemplo um processo que gerou uma história: a ação daqueles homens pode ser sentida até os nossos dias e a narrativa de seus feitos a torna algo tangível e atual por seus resultados (mesmo que ela tenha acontecido e existido apenas no momento de sua realização). Assim, um ato contém em si a capacidade de mudar a condição de um povo.

Os atores das diferentes histórias - que são vários, pois cada história não pode ser nunca realizada em isolamento - não tiveram a oportunidade de observar o alcance de seus feitos, o que só foi possível depois de sua morte. Essa imprevisibilidade da ação está relacionada à reação que ela provoca nos homens que a presenciam, ou que com ela estão 
relacionados mesmo que distantes do momento em que ela se deu, por sofrerem suas consequências posteriores: por isso, quanto mais visibilidade a ação conquista, maior é seu alcance. Estamos imersos numa teia de relações que une os homens entre si através de suas ações. Por essa razão somos agentes e pacientes da história, que nunca pode ser prevista por ser sempre resultado do novo e inesperado.

A história, iniciada com um ato, continua como os círculos gerados por uma pedra que cai na água. A narrativa a seu respeito nada mais é do que o discurso elaborado pelos outros para atribuir sentido a algo absolutamente fugaz, mas que se perpetua entre nós. A irreversibilidade é também característica da ação, já que depois dela o mundo não é mais o mesmo e não poderá sê-lo. É, portanto, impossível prever seu alcance e consequências pelo fato de o novo estar contido nela. A ação ao se realizar não tem fim: tanto por suas consequências serem imprevisíveis, quanto por não ser capaz de predizer finalidade; é, porém, movida por um princípio $^{15}$ inspirador. Portanto, a atividade política da ação não pode ser pensada a partir das categorias de meios e fins: na ação ambos só podem ser concebidos como sendo o próprio ato. A imprevisibilidade, que é sua condição, não permite que ela seja pensada a partir dessas categorias.

Ambas as atividades políticas do discurso e da ação, por estarem unidas à revelação de quem somos, precisam da presença de outros e, portanto, não são possíveis em isolamento (diferentemente do labor e da fabricação). Essa visibilidade exigida pela ação e pelo discurso para que tenham sentido só pode se realizar na esfera pública. A política (assim como a fabricação depende da matéria-prima para sua realização) só pode acontecer na relação entre os homens: é a pluralidade que gera a esfera pública na qual nos revelamos. Sendo assim, a pluralidade - que é fundamento da política - se apresenta como condição do discurso e da ação. Da mesma maneira, a liberdade - que é o sentido da política - se identifica com essas atividades que, desvinculadas em absoluto da necessidade, são capazes de iniciar e fundar algo entre nós. Portanto, não restam dúvidas sobre o caráter político dessas atividades quando realizadas num espaço de visibilidade e estão dedicadas às questões de nossa vida em comum.

15 “Princípios não operam no interior do eu como o fazem motivos - 'a minha própria perversidade', ou meu ‘justo equilíbrio' -, mas como que inspiram do exterior, e são demasiado gerais para prescreverem metas particulares, embora todo desígnio possa ser julgado à luz de seu princípio uma vez começado o ato. Pois, ao contrário do juízo do intelecto que precede a ação e do império da vontade que a inicia, o princípio inspirador torna-se plenamente manifesto no ato realizador; [...] o princípio que o inspirou nada perde em vigor e em validade através da execução. Distintamente da meta, o princípio de uma ação pode sempre ser repetido mais uma vez, sendo inexaurível [...]. Entretanto, a manifestação de princípios somente se dá através da ação, e eles se manifestam no mundo enquanto dura a ação e não mais. Tais princípios são a honra ou a glória, o amor à igualdade, que Montesquieu chamou de virtude, ou a distinção, ou ainda a excelência [...], mas também o medo, a desconfiança ou o ódio" (ARENDT, 2005b, p. 198-199). 


\section{EDUCAÇÃO E POLÍTICA: RELAÇÕES A SEREM COMPREENDIDAS}

\subsection{A educação no pensamento de Hannah Arendt e sua separação da política}

Ao longo da obra de Arendt encontramos raras menções à educação. Diferentemente do que acontece com a política, núcleo em torno do qual gravita todo o seu pensamento, o sentido da prática educativa é o objeto central de apenas um de seus textos. O ensaio A Crise na Educação, publicado na obra Entre o Passado e o Futuro, apresenta uma reflexão na qual a educação é pensada à luz da crise do mundo moderno e de algumas de suas manifestações. Para Elizabeth Young-Bruel $(1997)^{16}$, uma de suas principais biógrafas, a elaboração desse texto decorre da discussão política que Arendt enfrentou com a publicação do artigo Reflexões sobre Little Rock, no qual já é possível encontrarmos afirmações que revelam uma forma própria e incomum de entender a relação entre a educação e a política.

O elemento desencadeador das reflexões de Arendt são as experiências políticas de seu tempo. Sua obra resulta, fundamentalmente, da tentativa de compreensão de eventos relacionados à presença dos homens no mundo em sua relação com eles e entre si. Segundo Arendt (2002, p. 39), a compreensão é uma "atividade interminável, por meio da qual [...] aprendemos a lidar com nossa realidade, reconciliamo-nos com ela, isto é, tentamos nos sentir em casa no mundo". Compreender, portanto, não significa obter a revelação de alguma verdade, como no caso da contemplação; nem tão pouco desenvolver o raciocínio lógico e obter a partir dele uma conclusão necessária; ou ainda realizar uma investigação empírica que resulta em um novo conhecimento científico. Compreender é encontrar sentido, se realiza por meio do pensamento ${ }^{17}$ que parte da experiência e envolve julgamento. Assim, a compreensão

16 Cf. YOUNG-BRUEHL, 1997, p. 285.

17 "O pensar, contudo, não age, nem tem algum efeito direto sobre nosso agir; e, no entanto, é o único caminho para atribuirmos algum sentido àquilo que se passa no mundo, sendo nisso que consiste sua relevância. Pensar é retirar-se do mundo, sair do espaço movimentado dos acontecimentos e da presença dos outros, para poder refletir sobre o ocorrido. Ocorrências e acontecimentos não possuem um significado por si, mas se tornam significativos no momento em que, pensando-os, nos relacionamos com eles. De acordo com Arendt, o sentido de um fato não reside em sua estrutura lógica, nem em sua inserção numa sequência de causas e efeitos; também não diz respeito a um processo histórico maior que lhe atribua algum significado teleológico, mas pode surgir quando transformamos meros fatos em uma história (estória, story) humanamente compreensível. Com isso, no entanto, não se chega a um sentido definitivo. Pelo contrário, a cada acontecimento é preciso começar a reflexão de novo, já que o pensar - diferentemente do que se possa 
sobre qualquer evento que se dê entre os homens e que nos deixe desconfortáveis no mundo pode nos devolver o sentimento de que estamos mais uma vez em casa, reconciliados, mesmo que a discordância motivadora permaneça. A tentativa de realização da integração racial por meio das escolas foi um desses eventos que causou em Arendt profundo mal-estar, desencadeando um esforço de compreensão que resultou no artigo Reflexões sobre Little Rock.

O final da década de 50 nos Estados Unidos foi marcado pelo intenso enfrentamento do tema da segregação racial. A decisão da Suprema Corte Americana, que garantia o direito de estudantes negros de frequentarem as mesmas escolas que jovens brancos, deu início a um processo de integração. Tal determinação provocou reações da comunidade branca segregacionista, que passou a se manifestar de forma violenta diante das instituições definidas para serem o palco dessa transformação.

Foi em meio a cartazes agressivos e gritos de ofensa, resultantes da longa construção histórica da ideia de uma suposta superioridade branca, que os primeiros jovens negros foram recebidos na Little Rock Central High School. Tal acontecimento foi noticiado nos jornais do país acompanhado da foto de uma jovem negra escoltada por alguns adultos brancos que a protegiam de um grupo numeroso de segregacionistas. $\mathrm{O}$ ambiente de hostilidade e violência retratado nessa imagem provocou em Arendt grande indignação. Em Reflexões sobre Little Rock, ela analisa esse evento a partir de sua perspectiva teórica e categorias conceituais, e expõe um julgamento bastante peculiar sobre a situação. A discussão se inicia a partir das seguintes perguntas, que Arendt (2004, p. 261-263) dirige a si mesma: "o que eu faria, se fosse uma mãe negra?" e "o que eu faria se fosse uma mãe branca do sul?". Ao envolver-se diretamente com a situação através dessas questões, sua experiência como judia ganhou ressonância e fez de sua reflexão um forte posicionamento pessoal sobre o evento.

Segundo Young-Bruehl ${ }^{18}$, Arendt sofreu fortes críticas ${ }^{19}$ por esse artigo. Primeiro, por afirmar que a comunidade negra deveria manifestar, antes de mais nada, repulsa às leis contra a miscigenação (contra os casamentos entre negros e brancos, o que na época permanecia

esperar dele - não produz sabedorias perenes, nem conhecimentos, nem teorias acabadas" (ALMEIDA, 2009, p. 119).

18 Cf. YOUNG-BRUEHL, 1997, p. 280.

19 Ainda hoje, Reflexões sobre Little Rock provoca fortes discussões dentre muitos que se dedicam ao estudo das obras de Arendt. Uma das razões está no fato representar uma tentativa de realizar a aplicação de seus conceitos a uma realidade empírica. Outro motivo da discussão se dá pelo próprio tema que o permeia: a ascensão da esfera social (tema que envolve a delimitação conceitual de público e privado realizada por Hannah Arendt e que é motivo de discussões e discordâncias). 
ilegal em vários estados norte-americanos). Além disso, em vez de apoiar um processo de integração por meio das escolas públicas, ela afirma ser direito exclusivo dos pais - e não objeto de política do Estado - definirem na companhia de quem seus filhos devem estudar. Portanto, segundo Arendt, os jovens não deveriam ser expostos a uma situação de luta pela efetivação da igualdade constitucional: esta deveria ser travada politicamente entre adultos e se traduzir no combate às leis segregacionistas.

Essas considerações apontam para uma das manifestações da crise da modernidade: a emergência da esfera social, representada nesses eventos fundamentalmente pela transposição de questões de fórum privado para o âmbito político (tema central de Reflexões sobre Little Rock). Assim, segundo Arendt, a decisão sobre com quem posso me casar não deve sofrer intervenção legal, tanto quanto a decisão sobre com quem meus filhos devem estudar. A indistinção entre os âmbitos público e privado, a força da emergência da esfera social e a importância da questão política e legal da emancipação dos negros parecem ser os pontos centrais do artigo. Portanto, embora Reflexões sobre Little Rock tenha sido desencadeado por um evento que envolveu diretamente o sistema escolar, a educação não é prioritariamente seu tema.

É apenas em A Crise na Educação que esse tema emerge como centro de sua discussão. Nesse ensaio, a crise que atinge a educação é refletida a partir da crise no mundo moderno e algumas de suas expressões, dentre elas a crise da tradição, a crise da autoridade e o impacto do pragmatismo nas teorias educacionais. Com a perda da tradição, esvaiu-se a segurança em relação à escolha das experiências comuns fundamentais a serem comunicadas às novas gerações. Com o declínio da autoridade, o lugar de responsabilidade a ser assumido pelos adultos para com as crianças já não é facilmente reconhecido. Com o advento e a supremacia do pragmatismo, a própria noção do conhecimento sofreu transformações substanciais, tornando a teoria e a prática educativa um tema de ordem técnica e lhe conferindo, acima de tudo, um caráter utilitário (e retirando da educação, em grande medida, seu sentido humanista).

Uma das dificuldades de A Crise na Educação está na ambiguidade que encontramos no uso do termo educação. Ora Arendt recorre a ele para se referir a um processo formativo geral - não necessariamente relacionado à instituição escolar, que é apenas uma das maneiras de a educação se realizar, típica desde a conformação dos Estados Nacionais e da Era Moderna -, ora é de fato a situação da escola que está sendo considerada. A introdução do 
texto, que apresenta a justificativa para essa reflexão, faz referência à crise da instituição escolar propriamente dita (tema recorrente nos noticiários americanos da época). No entanto, ao buscar compreendê-la, Arendt se coloca a refletir sobre a razão de ser da educação no mundo. Quando isso acontece, suas considerações extrapolam a reflexão sobre a situação da escola para nos oferecer uma ampliação desse conceito: a educação passa a ser entendida como uma das formas de responsabilidade pelo mundo e pelas crianças, que envolve, assim, todos os adultos (e não apenas os que estão implicados profissionalmente com ela). A importância da reflexão sobre a situação da escola propriamente dita se deve ao fato de que o próprio mundo moderno a criou e a escolheu como a instituição que desempenha prioritariamente a responsabilidade pela tarefa de educar (assumida pelo mundo público, nesse caso representado pelo Estado).

Normalmente a criança é introduzida ao mundo pela primeira vez através da escola. [...] Ela é [...] a instituição que interpomos entre o domínio privado do lar e o mundo com o fito de fazer com que seja possível a transição, de alguma forma, da família para o mundo. Aqui, o comparecimento não é exigido pela família, e sim pelo Estado, isto é, o mundo público, e assim, em relação à criança, a escola representa em certo sentido o mundo, embora não seja ainda o mundo de fato (ARENDT, 2005b, p. 238).

Enquanto em Reflexões sobre Little Rock a educação é apenas uma circunstância para o debate acerca de uma situação política, em A Crise na Educação ela é seu tema central. Nesse ensaio a própria educação é pensada em relação às condições do mundo moderno e de sua crise. Há, contudo, um ponto em especial que nos interessa em Reflexões sobre Little Rock: as razões que levaram Arendt a tecer considerações desfavoráveis à integração racial por meio do livre acesso de jovens negros às escolas que, até então, atendiam exclusivamente os considerados brancos. Para ela, “[...] a própria tentativa de começar a dessegregação na educação e nas escolas não tinha apenas deslocado, e muito injustamente, a carga da responsabilidade dos ombros dos adultos para os das crianças" (ARENDT, 2004, p. 262).

O que Arendt reprova não é a criação de políticas de integração, mas o fato de que a Suprema Corte Americana tenha delegado às crianças a solução de uma questão a ser discutida, encaminhada e solucionada entre adultos. Segundo Arendt, a responsabilidade a ser assumida diante do tema da integração racial não pode ser atribuída a nenhum outro âmbito 
que não o da própria política. Arendt (2004, p. 265), então, aponta para o problema que pode representar a tentativa de estabelecer a partir da educação alguma realidade de mundo, seja ela qual for.

\footnotetext{
Uma última palavra sobre a educação e a política. A ideia de que se pode mudar o mundo educando as crianças no espírito do futuro tem sido uma das marcas registradas das utopias políticas desde a Antiguidade. O problema com essa ideia tem sido sempre o mesmo: só pode dar certo se as crianças são realmente separadas de seus pais e criadas em instituições do Estado, ou doutrinadas na escola [...]. É o que acontece nas tiranias.
}

Arendt considera impraticável (e indesejável) a tentativa de estabelecer transformações políticas por meio da educação e critica sua utilização como recurso para a resolução de assuntos políticos. Tornar a educação um meio para fins de natureza política significa instrumentalizá-la como se seus resultados pudessem ser absolutamente previsíveis. Considerar que isso seja possível - e desejável - nada mais é do que crer que a educação e a política tenham uma lógica de funcionamento análoga à da fabricação, desconsiderando a imprevisibilidade inerente a ambas as atividades. A doutrinação seria condição necessária para tal empreendimento que - segundo o pensamento de Arendt - seguramente viria a fracassar, pois o curso do mundo não pode ser antecipado.

É interessante notar que considerações como essas de Reflexões sobre Little Rock voltam a emergir em A Crise na Educação e geram outras proposições sobre uma radical separação entre os âmbitos da educação e da política.

O papel desempenhado pela educação em todas as utopias políticas, a partir dos tempos antigos, mostra o quanto parece natural iniciar um novo mundo com aqueles que são por nascimento e por natureza novos. No que toca à política, isso implica obviamente num grave equívoco [...]. A educação não pode desempenhar papel nenhum na política [...] (ARENDT, 2005b, p. 225).

Essa radical separação entre os dois âmbitos tem sido alvo de muitas críticas e pouca compreensão em relação ao seu sentido e alcance. Ao se referir às consequências da crise da 
autoridade e da tradição no mundo moderno, Arendt mantém a força da afirmação e apresenta essa separação como um imperativo.

Cumpre divorciarmos decisivamente o âmbito da educação dos demais, e acima de tudo do âmbito da vida pública e política [...] (ARENDT, 2005b, p. 246).

Comumente essas proposições têm sido interpretadas - e criticadas - como se no pensamento de Arendt os âmbitos da política e da educação fossem estanques e independentes. No entanto, é fundamental atentarmos para o fato de, em algumas situações, ela ter se referido à educação como um âmbito pré-político, anunciando algum outro tipo de relação para além da separação radical estabelecida. Nos dedicaremos a refletir, então, sobre o que isso vem a significar para a relação entre a educação e a política.

\subsection{As relações existentes entre o que é pré-político e a própria política}

Como vimos, além da separação radical estabelecida entre a educação e a política, encontramos em A Crise na Educação outros elementos que apontam para relações mais complexas e menos evidentes entre elas. No entanto, por permanecerem muitas vezes obscuras ou por parecerem apontar algo mais profundo, convidam a uma reflexão a ser realizada a partir do conjunto do pensamento político de Arendt para que possam ser compreendidas. Um elemento importante a ser considerado é o emprego da expressão prépolítica para referir-se à educação.

Evidentemente, há uma conexão entre a perda de autoridade na vida pública e política e nos âmbitos privados e pré-políticos da família e da escola (ARENDT, 2005b, p. 240, grifo nosso). 
A perda geral de autoridade, de fato, não poderia encontrar expressão mais radical do que sua intrusão na esfera pré-política, em que a autoridade parecia ser ditada pela própria natureza e independer de todas as mudanças históricas e condições políticas (ARENDT, 2005b, p. 241).

A expressão pré-política, utilizada nesses trechos para designar a educação, evidencia uma relação entre ela e a política (embora os contextos de sua aparição, ao menos em A Crise na Educação, não tenham muito a nos revelar sobre o que isso significa). Mesmo diante da falta de elementos neste ensaio para realizarmos nossa reflexão, o que vale considerarmos, antes de mais nada, é que o prefixo pré- estabelece uma relação de antecedência entre os elementos que a expressão anuncia, nesse caso, entre a educação e a política. Mas qual o significado contido no fato de a educação preceder a política?

O uso dessa expressão não parece ser apenas a de simples relação de anterioridade temporal. Isso é facilmente reconhecido quando verificamos que não criamos expressões como essa cotidianamente apenas para expressar que algo antecede temporalmente outra atividade. Portanto, a utilização da expressão pré-política só faz sentido se a relação de antecedência apontar para algo mais profundo (assim como compreender o conceito de PréHistória é mais do que saber que se trata de um período temporalmente anterior ao que chamamos de História, mas supõe entender o que ela mesma representa para essa época subsequente, preservando suas distinções, mas também compreendendo o que, em si, ela significa). Além disso, as situações específicas de uso da expressão pré-política no pensamento de Arendt apontam para mais do que a simples relação de anterioridade temporal. Por essa razão é importante compreendermos o significado dessa expressão e as outras possíveis relações que ela estabelece com a própria política.

Outro motivo que nos leva a pensar que o uso desse termo revela algo mais profundo a respeito da relação entre os âmbitos da educação e da política são os conceitos que já sabemos serem essencialmente comuns a ambas, a saber, a natalidade e o mundo, o que mais tarde consideraremos. No entanto, antes de chegarmos a uma reflexão que envolva esses dois conceitos e se refira à educação propriamente dita, nos dedicaremos a encontrar outros momentos no pensamento de Arendt nos quais ela faz referência à expressão pré-política para designar outras situações, para que possamos dessa forma compreender seu significado. É dessa maneira que nossa reflexão ganhará elementos a partir do conjunto da obra política de Arendt para podermos pensar as possíveis razões de a educação estar assim designada. Tal 
esforço é necessário, pois, além de essa expressão ser utilizada pouquíssimas vezes durante seus escritos, Arendt não se dedica a explicar seu significado. No entanto, os contextos em que a expressão pré-política é utilizada apontam um mesmo tipo de relação entre tudo aquilo a que ela se refere e a própria política. É essa relação que procuraremos identificar e, mais tarde, compreender no que se refere à educação.

Um dos usos que encontramos para essa expressão faz referência à elaboração das leis da polis. No capítulo sobre A solução Grega (2005a), contido em A Condição Humana, encontramos:

\footnotetext{
Embora seja certo que Platão e Aristóteles promoveram a legislação e a construção de cidades ao mais alto nível da vida política, isto não quer dizer que eles tenham ampliado o campo das experiências gregas fundamentais - a ação e a política - para incluir aquilo que mais tarde viria a ser o gênio político de Roma: a legislação e a fundação. A escola socrática, ao contrário, recorreu a estas atividades, que os gregos consideravam pré-política, por desejar combater a política e a ação. Para os socráticos, a legislação e a ratificação de decisões pelo voto eram as mais legítimas atividades políticas, porque nelas os homens 'agem como artesãos': o resultado da ação é, em seu caso, um produto tangível e o processo tem um fim claramente identificável. A rigor, não se trata mais, ou melhor, não se trata ainda de ação (praxis), mas de fabricação (poiesis), a qual preferem em virtude de sua maior confiabilidade. É como se quisessem dizer que só haveria solução para a fragilidade dos negócios humanos se os homens renunciassem à sua capacidade de agir, uma vez que toda ação é fútil, ilimitada e de resultados incertos (ARENDT, 2005a, p. 207-208, grifo nosso).
}

Nesse trecho Arendt anuncia duas maneiras de entender o caráter da elaboração das leis na Antiguidade: a presente entre os romanos, que entendiam ser ela uma atividade política; e a que encontramos na experiência da polis grega, onde a confecção das leis era uma realização anterior à atividade política e, portanto, diferente dela. Para a compreensão do significado da lei para a política, Arendt recorre a essas duas experiências iluminadoras. Por essa razão, compreenderemos primeiramente sua relevância no caso da política romana para, em seguida, a distinguirmos da situação presente na experiência grega.

Em $O$ que é política?, Arendt (2007, p. 109) apresenta a gênese do conceito de lei para os romanos a partir da guerra. 
[...] é da maior importância que a Guerra de Tróia repetida em solo italiano, a qual o povo romano atribui sua existência política e histórica, não terminasse de novo, por seu lado, com o aniquilamento dos derrotados, mas sim com uma aliança e um tratado.

Segundo Arendt (2007, p. 95), os romanos consideravam a si mesmos descendentes dos troianos derrotados na guerra e atribuíam a esse evento (assim como os gregos) o início de sua existência histórica. Os romanos, na posição daqueles que depois de derrotados venceram, ofereceram, então, um novo sentido às guerras entre povos. O final das guerras romanas, em vez de ter como resultado a aniquilação do inimigo, tinha como consequência um acordo entre as partes envolvidas. Assim, "Contrato e aliança, de acordo com sua origem e seu conceito cunhado tão ricamente pelos romanos, estão ligados, [...] com a guerra entre povos e, segundo a concepção romana, representam a continuação natural, por assim dizer, de toda e qualquer guerra" (ARENDT, 2007, p. 109-110).

As narrativas de Homero, na leitura de Arendt, revelavam que ele reconhecia que de qualquer encontro entre homens surgia algo comum a eles, já que as partes envolvidas tornavam-se "os dois lados de um mesmo acontecimento" (ARENDT, 2007, p. 110). Essa consequência era obtida mesmo dos encontros mais hostis, afinal, quando a guerra era interrompida antes da aniquilação de uma das partes, a própria interrupção era capaz de gerar uma nova maneira de estas estarem juntas. Isso, no caso dos romanos, significava que quando as ações violentas eram abandonadas como a forma de relação estabelecida entre os envolvidos, tinha início uma nova relação, mediada pela palavra, que pretendia estabelecer entre eles um acordo (e a vitória para os romanos, portanto, representava na realidade a constituição de um novo espaço político). Portanto, “o fazer da lei, essa ligação duradoura que se segue à guerra violenta, é ele mesmo ligado à conversa e à réplica [...] algo que, tanto na opinião dos gregos como na dos romanos, estava no centro de tudo que é político" (ARENDT, 2007, p. 112).

No entanto, para Arendt (2007, p. 110-111), “contrato e aliança enquanto concepções centrais da coisa política são, em termos históricos, [...] de origem romana, mas [...] são estranhas, em sua essência mais profunda, ao caráter grego e à sua concepção do âmbito da coisa política, ou seja, da polis". Tal fato está relacionado ao sentido da política romana e, ao 
mesmo tempo, relacionado também aos limites nos quais estava circunscrita a atividade política para os gregos. No caso dos romanos, a expansão de seu espaço político oferecia identidade a esse povo, fazendo da experiência do contrato e da aliança algo fundamental para sua continuidade. Já no caso dos gregos, embora a guerra com outros povos tenha oferecido sentido para a criação da polis (já que, como vimos, com seu estabelecimento os cidadãos conquistaram um espaço de ação permanente, inspirado na experiência dos atores das narrativas de Homero), a atividade política estava circunscrita aos muros da cidade. Assim, no caso dos romanos - mas não no caso dos gregos -, a solução para a questão da guerra, a saber, o contrato e a aliança, constituía a origem do conceito de lei para esse povo e tornava sua elaboração uma de suas principais atividades políticas.

[...] é decisivo que só para os romanos a atividade legisladora e com isso a própria lei caíam no âmbito da verdadeira coisa política, ao passo que segundo a concepção grega a atividade do legislador era tão radicalmente separada das verdadeiras atividades e ocupações políticas dos cidadãos dentro da polis que o legislador nem ao menos precisava ser cidadão da cidade, podendo ser contratado de fora (ARENDT, 2007, p. 112).

Foi, portanto, a experiência romana que tornou a atividade de legislar uma atividade essencialmente política, diferentemente do que aconteceu entre os gregos. No contexto da polis, a confecção das leis não era realizada através da política propriamente dita (não era elaborada pelos cidadãos na ágora a partir do confronto dos discursos e também da persuasão), mas era o produto de uma atividade como a do artífice que se dedicava a construir os objetos da cidade ou até mesmo seu marcos e limites concretos. As leis, portanto, eram realizadas não a partir da ação e do discurso, mas entendidas como o resultado de um fazer como a fabricação. Sendo assim, a atividade de legislar - atividade pré-política - antecedia as relações políticas, propriamente ditas, da polis. É a partir do reconhecimento das condições de realização da atividade de confecção das leis nesse contexto que se evidencia a primeira relação entre o que é pré-político e o que é político: a distinção, afinal apenas a ação e o discurso constituem-se atividades políticas, não a fabricação.

Outra constatação a respeito do significado da expressão pré-política, e que também advém do reconhecimento de que a confecção das leis no contexto da polis não se dava entre os cidadãos, é a relação de antecedência à atividade política. A atividade pré-política de 
elaboração das leis é anterior à política: “o legislador, portanto, não precisava ser um cidadão, muitas vezes era mandado vir de fora. Seu trabalho não era político; a vida política, porém, só podia começar depois que ele houvesse terminado sua legislação" (ARENDT, 2005a, p. 74, grifo nosso).

Embora legislar não fosse propriamente uma atividade política, o conjunto de leis da polis era o que oferecia limites para as ações dos homens que nela viviam e conferia a personalidade de cada cidade, e, como Arendt mesmo afirmou, a política dependia de tais leis. Nesse sentido, elas desempenhavam papel fundamental para a atividade política, mesmo não sendo resultado dela. Portanto, Arendt (2007, p. 115) entende que as leis representavam as fronteiras dentro das quais os cidadãos eram livres, sendo necessárias para que o espaço político estivesse conformado e assegurado, da mesma maneira que a delimitação das fronteiras da cidade era necessária para a conformação da polis ${ }^{20}$. Essa dimensão de antecedência necessária das leis em relação à política no contexto da polis (anunciada já na citação do parágrafo anterior) está expressa no trecho a seguir.

\footnotetext{
Antes que os homens começassem a agir, era necessário assegurar um lugar definido e nele erguer uma estrutura dentro da qual se pudessem exercer todas as ações subsequentes; o espaço era a esfera pública da polis e a estrutura era a sua lei (ARENDT, 2005a, p. 207, grifo nosso).
}

Portanto, além de a lei ser anterior à atividade política dos cidadãos gregos, era também necessária a ela, já que oferecia os limites para a ação. No entanto, sua importância para a política não estava apenas relacionada aos limites estabelecidos por ela para os movimentos dos homens na cidade, mas também à condição de reuni-los em torno dela. No caso do contexto da polis, as leis ofereciam uma identidade comum para os cidadãos, revelavam parte fundamental do mundo do qual faziam parte os homens de cada cidade em particular. Portanto, apesar de não serem uma realização política, as leis eram fundamentais a esta, pois é sobre elas que estavam assentadas as ações na polis, além de representarem algo

20 Na primeira citação deste capítulo a própria construção da cidade é entendida como uma atividade prépolítica. Retomando: "Embora seja certo que Platão e Aristóteles promoveram a legislação e a construção de cidades ao mais alto nível da vida política, isto não quer dizer que eles tenham ampliado o campo das experiências gregas fundamentais (...). A escola socrática, ao contrário, recorreu a estas atividades, que os gregos consideravam pré-políticas, por desejar combater a política e a ação" (ARENDT, 2005a, p. 207-208). Portanto, mais uma vez algo que é entendido como resultado da fabricação no contexto da polis é entendido como sendo algo pré-político. 
fundamentalmente comum àqueles cidadãos. O conjunto de leis de uma cidade da Antiguidade Grega representava aquilo que os unia e que organizava as relações políticas naquele espaço. Essa relação entre o que é pré-político e a própria política, no caso da lei no contexto da polis, fica ainda mais evidente na citação abaixo:

\begin{abstract}
A lei, como os gregos entendiam, não era acordo nem contrato, não surgiu entre os homens no falar de duas partes e no agir e contra-agir e, por conseguinte, não era algo inserido no âmbito político, mas é, em essência, imaginado por um legislador e precisa ser aprovado, antes de poder entrar na verdadeira coisa política. Como tal, é pré-política, no sentido de ser constitutiva para todo ulterior agir político e o lidar politicamente entre si. Assim como os muros da cidade (com) os quais Heráclito compara a lei, precisam ser construídos primeiro antes de poder existir uma cidade identificável em sua forma e em suas fronteiras, a lei determina a verdadeira fisionomia de seus habitantes, através da qual ela se distingue e sobressai de todas as outras cidades e seus habitantes. A lei é a circunvalação-fronteira produzida e feita por um homem, dentro da qual nasce então o espaço da verdadeira coisa política [...] (ARENDT, 2007, p. 113-114, grifo nosso).
\end{abstract}

Identificadas as relações de distinção, antecedência e necessidade entre o que é prépolítico e a própria política, no caso específico da lei na Grécia Antiga, recorreremos a outro uso dessa expressão no pensamento de Arendt. Em A Condição Humana encontramos seu emprego mais uma vez relacionado a uma experiência concreta da Antiguidade Grega, nesse caso a esfera privada e os meios de ela se realizar e se manter preservada.

O ser político, o viver numa polis, significava que tudo era decidido mediante palavras e persuasão, e não através de força ou violência. Para os gregos, forçar alguém mediante violência, ordenar ao invés de persuadir, eram modos pré-políticos de lidar com as pessoas, típicos da vida fora da polis, característicos do lar e da vida em família, na qual o chefe da casa imperava com poderes incontestes e despóticos (ARENDT, 2005a, p. 35-36, grifo nosso).

Nesse trecho, encontramos novamente uma relação de distinção entre o que é político e o que é pré-político: nesse caso a partir da distinção entre a forma de os homens se relacionarem na esfera privada e na praça pública. Encontramos, então, a contraposição 
presente entre o tipo de relação hierárquica estabelecida entre os homens no lar e as relações de igualdade presentes na política da Antiguidade Grega. A política se realizava pela partilha da palavra entre os iguais na ágora, ou seja, pela persuasão num espaço comum, enquanto as definições no lar se davam pela palavra definitiva de um único homem num espaço privado. $\mathrm{Na}$ ágora as tentativas de persuasão dependiam da igualdade estabelecida no próprio espaço político entre aqueles homens plurais; já na esfera privada, ordenar era a maneira de conduzir os assuntos que lhe eram próprios. Portanto, o que está contido na distinção entre as relações da esfera privada e da esfera pública das cidades gregas é o reconhecimento de que a violência $^{21}$, a hierarquia e a submissão não estavam presentes nas relações políticas. Mais uma vez, então, o uso da expressão pré-política revela a distinção entre o que é próprio do âmbito político e o que não é, afinal, o lugar da política é a esfera pública, não a esfera privada, e as relações entre os homens nesses âmbitos também se distinguem.

Afirmar que a violência não é, em si, política e, ao mesmo tempo, relacioná-la à vida privada não quer dizer que Arendt a aceite no âmbito do lar. Significa, no entanto, o reconhecimento de que, no contexto da polis, a posição do senhor justificava suas atitudes despóticas, as quais eram consideradas legítimas nas relações do âmbito privado - e, por isso, marcadas pela desigualdade e violência. A presença de escravos dedicados às tarefas de suprimento da vida no lar aponta o reconhecimento dessa legitimidade e revela um modo de pensar e de viver dos homens da polis grega, os quais aceitavam subjugar alguém para terem as necessidades da vida atendidas e para estarem liberados para a atividade política entre iguais na ágora. A respeito desse modo de pensar e proceder dos gregos, Arendt afirma: “[...] Uma vez que todos os seres humanos são sujeitos à necessidade, têm o direito de empregar a violência contra os outros; a violência é o ato pré-político de liberar-se da necessidade da vida para conquistar a liberdade do mundo" (ARENDT, 2005a, p. 40, grifo nosso).

Essa afirmação, no entanto, revela ainda mais um aspecto da relação entre o que é político e o que é pré-político, para além da distinção. A antecedência existente entre a manutenção da esfera privada da polis e a política também assume caráter de necessidade, já que para participar da atividade política os cidadãos precisavam estar liberados do cuidado de

${ }^{21}$ Não nos dedicaremos a refletir sobre o fenômeno da violência no âmbito da política no pensamento de Arendt, tema que ela aprofunda em vários de seus escritos, em especial em Sobre a Violência. Nesse texto, apesar de Arendt reconhecer que algumas interrupções do curso da História tenham se dado a partir de atos violentos, ela considera que a violência não é um fenômeno político legítimo, mas o poder sim (portanto violência e poder não são idênticos, embora muitas vezes se manifestem combinados no mundo). Assim, o que encontramos no pensamento de Arendt é a negação de algo que parece ser "[...] consenso entre os teóricos da política, da esquerda e da direita, no sentido de que a violência é tão somente a mais flagrante manifestação de poder" (ARENDT, 2009, p. 51). Arendt escapa dessa identificação e propõe outra compreensão sobre esses fenômenos. 
suas necessidades vitais (e para isso delegavam tais tarefas na esfera privada a seus escravos). Por essa razão, encontramos o caráter de necessidade presente na atitude despótica do senhor na esfera privada.

[...] o poder pré-político com o qual o chefe da família reinava sobre a família e seus escravos, e que era tido como necessário porque o homem é um animal 'social' antes de ser animal 'político', nada tem a ver com o caótico 'estado natural' de cuja violência, segundo o pensamento político do século dezessete, os homens só poderiam escapar se estabelecessem um governo que, através do monopólio do poder e da violência, abolisse a 'guerra de todos contra todos' por ' atemorizar a todos'. Pelo contrário, todo o conceito de domínio e de submissão, de governo e de poder no sentido em que concebemos, bem como a ordem regulamentada que o acompanha, eram tidos como pré-políticos, pertencentes à esfera privada, e não à esfera pública (ARENDT, 2005a, p. 41, grifo nosso).

Ao referir-se às diferenças presentes entre a vida dos cidadãos e dos escravos na polis e à condição de liberdade de um e de sujeição do outro, encontramos considerações de Arendt sobre o que já estava contido nas afirmações de Aristóteles (2007, p. 17) a respeito da cidade, que "para ser completa deve compreender escravos e indivíduos livres". A relação entre senhores e escravos era entendida no contexto da polis como absolutamente necessária para a manutenção da esfera privada, e, portanto, era legitimada a atitude do senhor de submeter às suas determinações a família e seus escravos. A forma de o senhor proceder em sua casa era a garantia de que as necessidades da vida estavam sendo atendidas e que ele poderia se dedicar a outras atividades, no caso à atividade política: sua condição de senhor no lar lhe oferecia a condição de cidadão na ágora. Portanto, como encontramos na citação do texto de Arendt, a necessidade do 'poder'22 do senhor na esfera privada está relacionada não só ao suprimento das próprias necessidades vitais, mas também à dependência entre as esferas pública e privada, entre a garantia da manutenção da vida e a consequente liberação para a atividade política. A liberação, portanto, é a condição pré-política da liberdade experienciada na esfera pública pelos cidadãos gregos.

Essa experiência da liberdade, entendida segundo Arendt como um fenômeno político, acontece num espaço público, caracterizado pela visibilidade e dedicado às questões comuns. No entanto, só existe uma esfera pública constituída quando a esfera privada se mantém

22 Aqui, como na citação que está sendo comentada, o termo poder está sendo utilizado em sua acepção corrente, e não da maneira que Arendt o define. 
preservada. A dependência entre essas esferas fica evidente quando procuramos explicar o que elas significam e o que é próprio a cada uma delas. Qualquer apresentação e reflexão a esse respeito se desenvolve a partir do constante estabelecimento de paralelos existentes entre elas e da afirmação de suas distinções, apresentando-as quase sempre através de comparações. Portanto, qualquer tentativa de reflexão a respeito tanto de uma quanto da outra não pode acontecer de maneira profunda se não revelar suas distinções e relações.

Outro fato que aponta para essa relação de dependência, embora também de distinção, é a compreensão de Arendt sobre o que ela chama de ascensão do social (algo que apresentaremos nos capítulos seguintes como sendo uma manifestação da crise do mundo moderno). Esta é entendida como a dissolução dos limites entre as esferas privada e pública: o limite que separava e mantinha suas distinções preservava também a existência das duas. Quando a fronteira se dilui, uma se confunde na outra e ambas têm suas existências ameaçadas.

A antecedência da esfera privada em relação à esfera pública na experiência da Antiguidade Grega se dá na medida em que a primeira precisa estar garantida para que a outra possa surgir ou se manter. Portanto, se a esfera pública é a esfera na qual se dá o fenômeno da política, ela precisa da esfera privada, então designada pré-política, para continuar existindo. Da mesma maneira a liberdade, conceito que Arendt considera ser a essência da política, só existe se houver entre os homens que a experienciam a liberação da necessidade.

\footnotetext{
O que todos os filósofos gregos tinham como certo, por mais que se opusessem à vida na polis, é que a liberdade situa-se exclusivamente na esfera política; que a necessidade é primordialmente um fenômeno pré-político, caracterizado na organização do lar privado (...) (ARENDT, 2005a, p. 40, grifo nosso).
}

Apresentamos, assim, até o momento, a atividade de legislar e as relações presentes na esfera privada como sendo pré-políticas, segundo a designação de Arendt. Ao considerarmos os contextos de aparição dessa expressão em relação às situações acima mencionadas, encontramos alguns elementos que nos permitiram compreender as relações entre o que está designado como pré-político e a política propriamente dita.

O primeiro ponto dessas considerações é o reconhecimento da distinção presente entre o que é pré-político e o que é político, afinal a elaboração das leis não era uma atividade resultante da ação e do discurso na polis, e a esfera privada não era o espaço das relações políticas. No entanto, no caso das experiências mencionadas, a distinção existente também 
aponta uma antecedência lógica entre o que é pré-político e o que é político, já que a política só se dava a partir das leis constituídas e da preservação da esfera relativa à manutenção da vida.

Essa relação de antecedência estava marcada também por uma relação de dependência: a política dependia da anterior definição das leis, assim como os cidadãos, antes de se dirigirem à ágora, precisavam ter a garantia de que alguém se dedicava a manter o suprimento de suas próprias necessidades vitais (a liberação era, portanto, condição anterior à liberdade). Assim, o que encontramos de mais surpreendente na relação entre o que é pré-político e a política é a relação de necessidade que tem a própria política daquilo que é - e deve ser anterior a ela, mas ao mesmo tempo é distinto, ou seja: daquilo que é pré-político. A política, portanto, para se dar no contexto da polis, necessitava da elaboração das leis, bem como da manutenção da esfera privada. A política, portanto, necessita do que é pré-político.

Todas essas relações entre o que é pré-político e a política encontradas a partir das experiências da polis valem também para a educação em relação à política. A distinção entre a educação e a política evidentemente já está expressa nas afirmações de Arendt a respeito da separação radical entre elas, afinal aquilo que deve estar divorciado não deve ser de forma alguma confundido.

No entanto, como compreender a relação de antecedência necessária da educação para com a política que encontramos entre aquilo que é pré-político e a política? Embora à primeira vista possa parecer estranho considerar que essa relação se dê entre coisas que devem permanecer separadas e que são entre si distintas, vimos que no caso das experiências da polis era exatamente essa a condição a estabelecida. Nos resta, então, refletir sobre as razões de essa relação existir no caso da educação e sobre como ela se dá. Antes de buscarmos compreender o que essas relações significam, e para que possamos fazê-lo com profundidade, é fundamental refletirmos sobre o que Arendt considera ser a essência da educação: a natalidade, conceito que também é central em seu pensamento sobre a política, para em seguida refletirmos sobre a responsabilidade pelo mundo que dela decorre nos dois âmbitos. 


\section{O CONCEITO DE NATALIDADE E A RESPONSALILIDADE PELO MUNDO}

\subsection{O conceito de natalidade na política e na educação}

Em A Condição Humana, Arendt (2005a, p. 16) nos apresenta o que considera ser as condições mais básicas às quais está sujeita a existência humana: "o nascimento e a morte, a natalidade e a mortalidade". Ao recorrer a dois termos diferentes para o que parece ser um mesmo fenômeno - nascimento e natalidade -, Arendt procurar ressaltar a dupla dimensão do nascer humano: a aparição de um novo ser na vida e de um ser novo no mundo. O nascimento de um homem representa sua entrada no ciclo biológico da Terra: todos os seres humanos nascem para a vida, assim como qualquer outro ser vivo de qualquer espécie. Porém, o fenômeno do nascimento dos homens sobre a Terra não pode ser compreendido sem considerarmos o que temos realizado e construído ao longo do tempo: o mundo que nos cerca e condiciona. Portanto, o que nos diferencia no momento do nascimento em relação às outras formas vivas é que nascemos não só para a vida, mas também para o mundo.

Por essa razão, quando uma criança nasce, dizemos que ela veio ao mundo. Essa expressão se refere exatamente à condição de mundanidade a que estamos sujeitos ao recebermos a vida pelo nascimento. Nascemos para um mundo no qual outros homens já estiveram, deixaram suas obras e também sua marca pela singularidade de suas ações. A natalidade, então, está intimamente relacionada à mundanidade, pois é a artificialidade do mundo que condiciona e diferencia nossa existência. Portanto, enquanto os outros seres vivos nascem apenas para a vida, nós homens nascemos também para um mundo que nos antecede e que medeia as relações que estabelecemos entre nós e com o espaço em que nos movemos. Somos introduzidos pelo nascimento a um espaço de objetos, instituições e símbolos para os quais os membros do grupo ao qual viemos atribuem e compartilham significados.

O nascimento de uma criança representa o começo da existência de alguém novo, absolutamente único no mundo, e esse ineditismo é, em si, um início: é, então, com a natalidade que aparecem para o mundo homens singulares. Já os seres que vivem imersos 
apenas em seu ciclo biológico, ao nascer se repetem. Isso se dá porque estes seguem suas vidas sem distinção, afinal buscam incessantemente, ao longo de toda a sua existência, sua própria manutenção: tanto de suas vidas individuais quanto da vida de sua espécie. Apesar da força imperativa da vida (e também da morte, que é condição do mesmo ciclo), os homens, que além de seres da vida são seres do mundo, têm sua condição de existência alterada.

O mundo que nos diferencia no momento do nascimento representa o espaço físico e simbólico que reúne os homens e permite a aparição de nossa singularidade. Portanto, a pluralidade enquanto fenômeno observável sobre a Terra só é possível porque os homens nascem incessantemente e sua singularidade pode ser observada no mundo comum. É no momento do nascimento que aparecemos pela primeira vez e de forma singular aos olhos dos outros: a natalidade atualiza nossa condição de pluralidade, que tem, em si, uma dimensão política no pensamento de Arendt, afinal "a política baseia-se no fato da pluralidade humana" (ARENDT, 2008, p. 144).

Porém, é com a ação que a natalidade deixa de ter apenas uma dimensão política potencial para ser, no mundo, um fenômeno político. A natalidade manifesta no momento do nascimento é apenas a primeira forma de aparição para o mundo de alguém enquanto novidade. Segundo Arendt, os homens nascem novamente quando agem, ou seja, confirmam sua aparição singular em meio a outros: "é com palavras e atos que nos inserimos no mundo humano; e esta inserção é como um segundo nascimento, no qual confirmamos e assumimos o fato original e singular do nosso aparecimento físico e original” (ARENDT, 2005a, p. 189). Portanto, a natalidade tem duas manifestações: no nascimento humano e na ação.

O nascimento de uma criança contém a promessa de uma aparição singular para o mundo em forma de ação. Por meio dela nossa singularidade se revela e tem a capacidade de estabelecer, de fato, algo novo para o mundo, já que assume significado e alcance político. Portanto, se o nascimento de um homem é um início por ser ele único, a ação traz em si essa mesma condição: a capacidade de instituir um começo (que é a realização e atualização do novo que promete cada criança ao nascer). Se o nascimento de cada homem representa um início e a própria ação tem capacidade fundadora, a natalidade cria as condições de possibilidade para a narrativa, afinal toda história tem um começo.

Relatar a vida de animais, que seguem seu curso natural, em busca de alguma diferenciação fundamental entre eles não faz nenhum sentido, pois talvez o único que possamos descrever seja a antiga associação de verbos: nasce, cresce, se reproduz e morre 
(cedendo lugar a outro que seguirá os mesmos passos). Essa descrição aplicada à vida humana retira dela a dimensão fundamental de sua humanidade: sua condição de novidade. Assim, para Arendt, é ainda mais radical a relação entre a ação e a natalidade. Afinal " [...] a vida sem discurso e sem ação [...] está literalmente morta para o mundo; deixa de ser uma vida humana [...]" (ARENDT, 2005a, p. 189). Portanto, a ação e o discurso são as atividades humanas por excelência, afinal com elas revelamos o que somos essencialmente: seres únicos. Com o nascimento de homens para o mundo, a pluralidade, que é o fundamento da política, se renova continuamente. Além disso, a ação, que manifesta a singularidade de cada homem, possibilitando o início de algo novo, é a forma de realização da política.

Paralelamente ao seu significado central na política, a natalidade é considerada por Arendt a essência da educação. Com a natalidade se revela o sentido da educação no mundo (tanto sua razão de existir quanto seu movimento em certa direção: da chegada da criança, que impõe a condição de ser novo, até o pertencimento ao mundo que a precede). A educação, portanto, pode ser entendida como o traço que conduz um ponto a outro: os novos em direção ao mundo e o mundo em direção aos novos. Educamos para permitir essa aproximação: da pessoa ao mundo e do mundo à pessoa - no sentido da responsabilidade que esta passa a assumir por ele e da conquista, por parte do homem, de sua condição mundana. Assim, não basta vir à vida para pertencer ao mundo humano, mas é necessário também que se receba, das mãos dos que nele habitam, uma herança.

Portanto, o "fato de que seres nascem para o mundo" (ARENDT, 2005b, p. 223) é a razão de ser da educação. Ela existe justamente porque o mundo foi e é produzido e concebido por nós como resultado concreto da atividade da fabricação e das consequências de nossas ações. Comunicar o mundo aos novos - e assim partilhar o que o constitui - é a maneira que encontramos de preservá-lo e, com isso, conservarmos também nossa humanidade. Ao educarmos nossas crianças permitimos que aquilo que nos foi deixado pelos homens no passado aos que vivem no presente possa permanecer, ligando-nos a eles e mediando nossas relações e ações.

O nascimento incessante de crianças impõe a permanente responsabilidade de que apresentemos a elas o mundo, que é capaz de conferir um sentido à nossa existência. Portanto, a natureza concebe a criança através do nascimento, mas a artificialidade do mundo é algo a ser apresentado. Assim, se o mundo não existisse e não fosse condicionante de nossa existência, bastaria dedicarmos às crianças os cuidados para a manutenção da vida, assim 
como no caso de qualquer outro animal. No entanto, a educação, para Arendt, envolve essa dupla responsabilidade: a de preservar a vida dos novos e também o próprio mundo que os antecede. A tarefa de educar é, então, a resposta que criamos para a dicotomia entre vida e mundo que a natalidade nos impõe, pois:

\footnotetext{
Os pais humanos [...] não apenas trouxeram seus filhos à vida mediante a concepção e o nascimento, mas simultaneamente os introduziram em um mundo. Eles assumem na educação a responsabilidade, ao mesmo tempo, pela vida e desenvolvimento da criança e pela continuidade do mundo (ARENDT, 2005a, p. 235).
}

Como vimos, no pensamento de Arendt, o conceito de natalidade é central tanto para a educação quanto para a política, apesar da separação estabelecida entre elas. Enquanto na política a natalidade se manifesta na ação, na educação o fato da natalidade é sua essência. Algumas perguntas passam, então, a guiar nossa reflexão: como dois âmbitos que tem a natalidade como conceito essencial e comum podem estar tão radicalmente separados? Que relação podemos encontrar, então, entre a educação e a política, para além da separação que Arendt estabelece entre ambas? O que a própria separação pode nos auxiliar na compreensão de suas relações? A natalidade, ao representar uma intersecção entre esses âmbitos, aponta para o fato de essa relação permanecer obscura em seus textos, sugerindo uma complexidade maior que a aparente. Uma reflexão sobre a responsabilidade da educação para com o mundo e para com a os novos pode nos apontar uma das relações possíveis que advêm da própria natalidade, além de oferecer sentido à identificação da educação como sendo um âmbito prépolítico.

\subsection{A responsabilidade pelo mundo advinda da natalidade}

Para refletir sobre a situação da educação e estabelecer suas relações com a crise do mundo moderno, vimos que Arendt apresenta o que considera ser a essência da educação: a 
natalidade. A educação é entendida, portanto, como um compromisso assumido por nós diante do fato de crianças nascerem a todo momento.

Essa chegada incessante de crianças à vida e ao mundo faz com que recaia sobre nós a responsabilidade de preservar suas vidas, as quais se mostram tão frágeis frente este ambiente tão vasto e desconhecido. Além disso, há também a responsabilidade de preservar o mundo preexistente desses recém-chegados que surgem e que podem destruí-lo se o desconsiderarem e não se perceberem parte dele. Assim, Arendt considera que a educação seja desempenhada a partir de uma atitude conservadora, não na acepção corrente do termo, mas num sentido bastante preciso de proteção. A educação é, então, um âmbito de preservação do que nela está envolvido.

[...] parece-me que o conservadorismo, no sentido de conservação, faz parte da essência da atividade educacional, cuja tarefa é sempre abrigar e proteger alguma coisa - a criança contra o mundo, o mundo contra a criança, o novo contra o velho, o velho contra o novo (ARENDT, 2005b, p. 242).

Nesse sentido a educação é motivada pelo princípio de conservação da própria criança - que precisa receber abrigo para que não esteja exposta ao mundo sem ter condições de defender-se de suas ameaças -, e pelo princípio de conservação do próprio mundo - para que este também não seja ameaçado pelo novo que irrompe sobre ele. A educação, então, preserva a criança quando mantém resguardada sua vida para que ela possa se desenvolver seguindo seu curso natural. No entanto, a existência humana envolve também experiências que se dão na relação com outros homens e com os objetos e espaços do mundo impregnados de símbolos e significados. Portanto, a educação implica também preservar o próprio mundo, pois este, quando comunicado e experienciado em sua significação, mantém-se entre nós, já que segue mediando nossas relações e determinando nossa existência.

Observamos esse princípio de conservação da educação manifesto mesmo em suas tarefas mais simples. Ensinar uma criança pequena a alimentar-se com o uso de talheres nada mais é do que introduzir esses objetos do mundo na relação da criança com sua própria vida biológica. Significa conferir aspectos de artificialidade a tarefas que são do âmbito do labor e da manutenção do ciclo vital, incorporando os resultados da fabricação na relação das crianças com a vida. Assim como ensiná-la a não colocar o dedo na tomada é não só uma 
atitude de preservação da vida, mas também de apresentação de algo do mundo.

Com o tempo, aspectos mais complexos do mundo, e muitas vezes menos tangíveis, são dados a conhecer aos jovens. Através da escola, por exemplo, as crianças são apresentadas à sistematização da estrutura de sua língua materna, bem como à linguagem matemática. Esses aspectos do mundo, em alguma medida, já são conhecidos por elas em função de suas experiências formativas em diferentes contextos ao longo de sua existência (afinal, quando chegam a essa etapa da aprendizagem escolar já se comunicam através de sua língua materna e veem números a todo momento ao seu redor). Porém, por meio da escola, nós adultos pretendemos que esses códigos sejam aprendidos pelos jovens em sua significação e aplicação comum mais variada e profunda.

Dessa forma, ao longo dessa trajetória, esses recém-chegados vão conhecendo mais e mais aspectos do mundo que vão assumindo um sentido compartilhado. Embora a preocupação com a vida dos novos esteja presente do começo ao fim dessa experiência formativa, quanto mais as crianças crescem e vão sendo educadas, mais a artificialidade do mundo vai sendo introduzida e os procedimentos que envolvem a preservação da vida vão abandonando seu lugar de maior relevância. O mundo vai progressivamente ganhando espaço.

Embora grande parte dessa tarefa venha sendo atribuída à escola, esta não pode ser confundida com o mundo propriamente dito, apesar de representá-lo junto aos jovens. Para Arendt (2005b, p. 238), "a escola não é de modo algum o mundo e não deve fingir sê-lo". Ainda que a escola não seja exatamente o mundo, ela aproxima as crianças dele ao comunicar alguns de seus aspectos para que estes possam ser preservados e mais tarde renovados. É evidente que nenhum desses aspectos é no mundo como é na escola: tanto em sua forma de existir quanto na maneira de as pessoas estabelecerem relação com eles. Os conhecimentos apresentados no currículo, por exemplo, são recortes transformados dos saberes elaborados culturalmente por um determinado povo e eleitos para serem transmitidos e conservados: na escola esses saberes recebem uma versão considerada adequada a seus propósitos. Outros exemplos são as relações entre iguais, ou ainda as relações com os espaços comuns. Estas se dão a partir de princípios que os educadores minimamente compartilham: não só advindos do mundo em que estamos inseridos, mas também da tradição da própria instituição escolar. A escola, então, embora não seja o mundo, aponta para ele.

Assim como há uma relação fundamental entre mundo e educação, sabemos que existe uma relação igualmente fundamental entre mundo e política, pois, como vimos, "a política 
surge entre os homens" (ARENDT, 2008, p. 146, grifo nosso). Sendo assim, será que não há qualquer responsabilidade da política para com o mundo que advenha também da natalidade, assim como na educação há um compromisso para com sua preservação?

Quando Arendt apresenta, em A Crise na Educação, que o conservadorismo é parte da essência da tarefa educativa, ela imediatamente faz uma ressalva em relação à política.

[...] isso permanece válido apenas no âmbito da educação [...]. Tal atitude conservadora, em política - aceitando o mundo como ele é, procurando somente preservar o status quo -, não pode senão levar à destruição, visto que o mundo, tanto no todo como em parte, é irrevogavelmente fadado à ruína pelo tempo, a menos que existam seres humanos determinados a intervir, a alterar, a criar aquilo que é novo (ARENDT, 2005b, p. 242).

Para compreendermos o significado dessas afirmações é importante nos referirmos aos conceitos de milagre e automatismo apresentados em Que é liberdade?. Nessa reflexão, Arendt não vincula o significado do termo milagre à sua acepção mais corrente, de cunho religioso, mas ressalta que seu sentido expressa uma experiência: a ocorrência de um evento absolutamente inesperado que se dá em meio a um curso de acontecimentos previsíveis (da natureza ou, especialmente, dos negócios humanos). O surgimento da vida orgânica sobre a Terra a partir de processos inorgânicos é para ela um de seus maiores exemplos. A existência de vida no planeta, além de conter algo de inexplicável do ponto de vista do previsível, representa, em algum ponto, a interrupção de processos automáticos. Porém, para Arendt, os milagres não são eventos que acontecem apenas na ordem biológica e natural, mas especialmente na dimensão histórica e artificial do mundo dos homens por meio da ação.

O milagre, apesar de estabelecer uma realidade absolutamente nova, depois que deixa de ser novidade gera processos tão repetitivos quanto os anteriores. A vida surgiu e, em seguida, passou a se repetir por um longo período, até que novamente se desse outra interrupção, que, por exemplo, eliminou certas espécies e gerou novas. Mas a inclinação para a repetição e o automatismo que existe nos processos biológicos também existe nos processos mundanos: a ação, depois de algum período de tempo como novidade, tende a estabelecer o mesmo movimento. 
Sem dúvida nenhuma, a vida humana situada sobre a Terra é circundada por processos automáticos: pelos processos terrestres naturais, por seu turno envolvidos por processos cósmicos e sendo nós mesmos impelidos por forças similares na medida em que fazemos parte também de uma natureza orgânica. Nossa vida política, além disso, a despeito de ser o reino da ação, faz parte também desses processos que denominamos históricos e que tendem a se tornar tão automáticos como os processos cósmicos ou naturais, embora tenham sido acionados pelo homem. A verdade é que o automatismo é inerente a todos os processos, não importa qual possa ser sua origem [...]. É da natureza dos processos automáticos a que o homem está sujeito, porém no interior dos quais e contra os quais pode se afirmar através da ação, só poderem significar ruína para a vida humana. Uma vez que processos históricos e artificiais se tenham tornado automáticos, não são menos destruidores que os processos vitais naturais que dirigem nosso organismo e que em seus próprios parâmetros, isto é, biologicamente, conduzem do ser para o não ser, do nascimento para a morte (ARENDT, 2005b, p. 217).

Assim como os processos biológicos tendem a estabelecer um curso automático e inevitável para a morte, nos processos artificiais isso também acontece, pois tudo o que é novo tende, com o tempo, ao desgaste e à ruína. Arendt lembra os inúmeros casos de civilizações que tiveram seu auge, mas que ruíram pela estagnação de algo que um dia foi uma novidade até a mais completa decadência ou desaparecimento. Esses processos automatizados são os que ocupam mais tempo na história das civilizações: afinal tudo que é novo passa a ser velho um dia, pois nada é novidade para sempre. É por essa razão que Arendt (2005a, p. 258) manifesta profunda admiração pelas revoluções e fundações: elas são signos de que os homens “embora devam morrer, não nasceram para morrer, mas para começar".

Portanto, com o tempo, a história de um grupo de homens que é alterada por um evento novo termina por desencadear processos repetitivos: o movimento inicial, que é novo, faz o mundo girar pela sua propulsão, mas com o tempo perde força até a mais completa estagnação. Por essa razão Arendt se mostra convicta de que nenhum ato pode salvar a humanidade de maneira permanente, pois tudo o que é novo se torna velho (e tudo o que é velho tende ao desgaste e ao desaparecimento). Consequentemente, só a constante renovação do mundo pela ação permite que o mundo não seja destruído. A ação é a forma que os homens têm de realizar um milagre para o mundo e, assim, salvá-lo temporariamente da ruína. São os atos absolutamente improváveis e novos que retiram, por algum tempo, as civilizações dessa condição de automatismo. 
Essa renovação nada tem a ver com a destruição constante do que já existe: afinal, se ela for tão frequente quanto destrutiva, o ciclo automático se restabelece e o que era novidade deixa de sê-lo, equiparando o que acontece no mundo ao funcionamento do ciclo biológico da vida. Em contrapartida, a renovação que o mundo deve sofrer para ser preservado da ruína deve gerar também alguma estabilidade para os homens que nele existem. $\mathrm{O}$ mundo se caracteriza por ser um espaço no qual podemos nos mover em segurança. Portanto, a ação que funda o novo não deve ser confundida com o menosprezo pelo que já foi assentado no passado. Embora, muitas vezes, a ação de fato possa representar a negação de uma situação existente na qual se pretende colocar um fim definitivo (como, por exemplo, poderíamos dizer das ações pacifistas de Gandhi contra o sistema colonial até então vigente nos países em que atuou), a ação acontece a partir de um legado do passado, de um mundo já estabelecido.

É por essas razões que o novo que advém da natalidade no momento do nascimento é potencialmente renovador, mas não tem alcance político se não se atualizar na ação. Embora Arendt (2005b, p. 247) afirme que o mundo é "constantemente renovado pelo nascimento", ela reconhece que essa chegada incessante de crianças é também um ameaça para o mundo. Portanto, ele precisa ser protegido "para que não seja derrubado e destruído pelo assédio do novo que irrompe sobre ele a cada geração" (ARENDT, 2005b, p. 235). Logo, não basta que nasçam novos homens para que o mundo se renove e tenha durabilidade. $\mathrm{O}$ ritmo incessante do nascimento humano ainda se mostra mais vinculado ao ritmo estabelecido pela vida: sua novidade não é fundadora, mas emerge em forma de promessa de ação. Além disso, para que a natalidade seja fundadora, ela deve relacionar-se com o mundo existente, com o passado, com as histórias de um determinado grupo de homens: só assim adquire sentido e pode estabelecer algo novo para eles. Fundar uma realidade para o mundo dos negócios humanos só pode significar erigir uma novidade se houver algo anterior a ela do qual possa se diferenciar. É por essa razão que as crianças, ao nascerem, surgem inicialmente como uma novidade capaz de destruir o mundo tanto quanto de renová-lo. Por isso, a educação - que é a apresentação do mundo aos novos - se revela como uma das atividades humanas mais fundamentais segundo Arendt.

A reflexão sobre o conceito de milagre (e seu oposto, que é o automatismo) oferece sentido para a afirmação de A Crise na Educação sobre o conservadorismo na política. A preservação do status quo se revela o caminho certo para a destruição do mundo: logo, a única opção para sua continuidade é a renovação por meio da ação. Essa forma de pensar o mundo e 
sua continuidade é manifestação do amor mundi presente em toda a obra de Arendt. Seu significado para a política está expresso no seguinte trecho:

\footnotetext{
Não importa como pode ser feita a pergunta, se é o homem ou o mundo que corre perigo na crise atual, mas uma coisa é certa: a resposta que empurra o homem para o ponto central das preocupações do presente e que acha que deve modificá-lo, remediá-lo, é a política em seu sentido mais profundo. Pois, no ponto central da política está sempre a preocupação com o mundo e não com o homem - e, na verdade, a preocupação com um mundo assim ou com um mundo arranjado de outra maneira, sem o qual aqueles que se preocupam e são políticos, julgam que a vida não vale a pena ser vivida (ARENDT, 2007, p. 35, grifo nosso).
}

Amor mundi é o título que Arendt primeiramente havia escolhido para sua obra $A$ Condição Humana. Embora sejam raros os momentos nos quais ela faz referência a essa expressão, facilmente reconhecemos seu sentido quando lemos seus escritos: o amor mundi está presente na fé que ela deposita na ação humana, na supremacia das questões do mundo comum sobre as questões privadas, no fascínio que ela expressa por algumas de nossas heranças históricas. Vanessa S. Almeida (2009, p. 66), em sua tese intitulada Amor mundi e educação: reflexões sobre o pensamento de Hannah Arendt, considera a possibilidade de que Arendt não tenha mantido aquele título inicial para A Condição Humana para que o termo não fosse confundido com o sentimento amoroso (algo que existe no interior dos homens e que, portanto, localiza-se fora do mundo). Em A Crise na Educação encontramos uma referência explícita a esse amor ao mundo, relacionada à nossa atitude para com as nossas crianças e para com o próprio mundo.

A educação é o ponto em que decidimos se amamos o mundo o bastante para assumirmos a responsabilidade por ele e, com tal gesto, salvá-lo da ruína que seria inevitável não fosse a renovação e a vinda dos novos e dos jovens. A educação é, também, onde decidimos se amamos nossas crianças o bastante para não expulsá-las de nosso mundo e abandoná-las a seus próprios recursos, e tampouco arrancar de suas mãos a oportunidade de empreender alguma coisa nova e imprevista para nós, preparando-as em vez disso com antecedência para a tarefa de renovar um mundo comum (ARENDT, 2005b, p. 247). 
Assim, se na educação a possibilidade da continuidade da existência do mundo (entendida como um ato de amor ao mundo) se dá por meio de sua apresentação às crianças e da preservação de suas vidas, na política ela se dá por meio da possibilidade do novo contida na ação. Assim, embora possa parecer contraditória sua afirmação de que a política não deve ter uma atitude conservadora frente ao mundo, ela não o é, pois o sentido preciso da preservação do mundo na política é a renovação. Ele só continuará existindo se os homens agirem de maneira a renová-lo continuamente através da ação.

Portanto, em relação à continuidade do mundo, tanto a política quanto a educação assumem responsabilidades. Embora a educação assuma papel relevante para esse empreendimento, é apenas com a política que ele se realiza de forma decisiva. Só na política encaminhamos e reencaminhamos o curso do mundo: só ela, ao renovar, conserva. A conservação do mundo presente na educação está mais relacionada à estabilidade que o mundo deve nos oferecer, pois comunica o que já existe, pretendendo manter entre nós a intersubjetividade a que está sujeita a nossa existência. Assim, se educarmos nossas crianças, mas nada de novo for realizado pela política, o caminho do mundo seguirá na repetição e em direção à ruína.

A responsabilidade para com a continuidade do mundo é desempenhada, portanto, de maneira distinta em cada um desses âmbitos, mas se mostra comum a eles e se dá de maneira complementar. A educação, que desempenha o esforço permanente de aproximar os novos do mundo com um sentido de pertencimento e, portanto, responsabilidade, contribui para manter a possibilidade da ação futura, pois a política só pode se realizar no mundo no qual os homens plurais existem, se relacionam e se reconhecem. Educação e política, que ocupam lugares distintos no pensamento de Arendt, encontram na responsabilidade pelo mundo uma relação: evitar que ele desapareça, procurando - cada uma com sua forma e alcance - preservá-lo entre nós. A educação é a forma que encontramos de tentar oferecer uma condição mínima de preservação de algo que nos une e confere sentido à nossa existência para que a política possa de fato atuar a favor de sua continuidade por meio da ação.

A educação, em seu aspecto conservador, assume um compromisso no tempo presente para com o futuro. Ou seja: educamos hoje para que mais tarde as crianças possam reconhecer-se parte do mundo e vir a renová-lo quando adultos. Essa responsabilidade recai sobre cada um de nós ao nascermos: é a responsabilidade pela atualização do sentido de nosso nascimento - a aparição pela ação do novo que somos nós mesmos. A relação inegável que a 
educação estabelece com o futuro permite a elaboração de discursos que atribuem a ela responsabilidade pelas falências de uma determinada comunidade política. Apresenta-se naturalizada a ideia de que o fim das misérias do mundo está no futuro dos jovens. De acordo com tal premissa, devemos então, hoje, educar com vistas às mudanças que pretendemos no futuro. Tais discursos, aparentemente aceitáveis e razoáveis, podem, contudo, acentuar a desresponsabilização política, tão presente em nossos tempos.

As expectativas políticas quando depositadas sobre as novas gerações lançam a possibilidade de ação para um eterno futuro nunca alcançado. Isso significa que nós adultos estaríamos desresponsabilizados de qualquer fato do mundo, já que caberia à educação preparar os novos para desempenharem as transformações que esperamos. Porém, quando estes forem introduzidos ao mundo como jovens adultos, eles mesmos já estarão desresponsabilizados novamente, já que as expectativas de alteração do curso dos fatos estarão mais uma vez depositadas nos recém-chegados e a acontecer num tempo que qualquer um de nós jamais viveria. O fato é que a ação não deve ser entendida apenas como uma possibilidade futura. $\mathrm{O}$ equívoco está na situação confortável em que nos deixam os discursos que depositam na educação a responsabilidade pelo mundo, fazendo com que a ação, a responsabilidade e a política não sejam nunca realidade presente.

A esse respeito, vale considerarmos uma sutil diferença entre duas palavras que expressam coisas parecidas, mas não idênticas. Criar expectativa significa aguardar algo conhecido ou pretendido, com grande dimensão de certeza em seu conteúdo, forma e tempo. Em contrapartida, ter esperança a respeito de algo supõe uma abertura: está mais relacionado à crença de que algo pode vir a acontecer dentro de uma abertura de possibilidades, sem tempo ou forma definidos. Assim, o que encontramos no pensamento de Arendt não é a expectativa por algo estabelecido de antemão, mas algo mais próximo da esperança no novo: novo este que é possível em qualquer tempo em aberto.

Segundo Arendt, a forma de a educação desempenhar sua tarefa de responsabilidade para com o mundo é voltando o seu olhar ao passado - não ao futuro -, já que nele dispusemos o que existe entre nós. O passado contém nossa história, nossa identidade como seres do mundo. Educamos na esperança de que as heranças e histórias humanas possam manter-se vivas: é no passado que encontramos o significado e sentido de nossa existência mundana. No entanto, muitos dos discursos político-educacionais estão permeados da expectativa de um futuro pretendido a ser assentado por meio da própria educação, mas que, 
de fato, não tem nenhuma garantia de acontecer. Neles está a pretensão de erigir um mundo que existe apenas em nossas idealizações, ou ainda a crença ilusória de que se conhece o que ele um dia virá a ser. Tais discursos estão imersos nos sonhos de realização de um mundo que nós mesmos gostaríamos de ter sido capazes de haver edificado por nossas próprias mãos e ações.

Embora o futuro não exista (ou ao menos não possamos alcançá-lo, pois, por mais que o tempo passe, é sempre presente), comumente as fantasias a seu respeito se tornam guias das intenções e práticas educativas: como se tivéssemos a capacidade de antever com precisão a realidade futura e preparar nossos jovens para realizá-la conforme as nossas próprias expectativas. Mas se nos perguntarmos sobre que futuro é esse e encontrarmos respostas, estaremos desprezando a imprevisibilidade da ação. Tudo o que traçamos em nossas mentes se tornará passado quando o futuro chegar, graças ao movimento incessante do tempo a que nós e o mundo estamos sujeitos. Portanto, tudo o que desejemos ou planejemos para um tempo que ainda não existe se tornará algo absolutamente velho e, mais uma vez, no rumo da destruição: afinal, o que é novo hoje, amanhã não o é mais.

Portanto, educar crendo que somos capazes de estabelecer por meio desse processo uma realidade desejável, procurando obter resultados previsíveis para um tempo que não conhecemos, é, para Arendt, um equívoco. Pretender que a educação de hoje gere resultados certos para a política no futuro é retirar dos homens sua condição de novidade. Além disso, estabelecer um processo como esse nada tem a ver com a atividade política, mas sim com a atividade da fabricação: nela sim as categorias de meios e fins são válidas, mas não na política. É importante considerarmos que, já em Reflexões sobre Little Rock, Arendt reprovou a utilização da educação como meio para a transformação de uma situação de ordem política. A razão para isso é o fato de que, se não podemos (e não devemos) esperar da educação a fabricação de uma realidade de mundo futura, muito menos podemos criar expectativas a seu respeito sobre qualquer transformação política e pública imediata.

Realizar a tarefa de educar sob as condições da fabricação suporia uma conduta doutrinária, na qual qualquer espontaneidade perde seu lugar, pois suas bases e objetivos já estão dados. Se observarmos o curso da história dos homens, saberemos que se trata de ilusão considerar que os negócios humanos sejam previsíveis, ou que determinada iniciativa tenha consequências certas: as experiências das utopias políticas modernas já mostraram quão fracassadas são essas tentativas. Os governos tirânicos e também os totalitários evidenciaram 
essa impossibilidade e o quanto isso se mostra indesejável. Se no âmbito da política isso é facilmente verificável, no campo da educação também. A própria experiência educativa revela que o que ensinamos nem sempre é aprendido como imaginamos; que nossas práticas, palavras e atitudes atingem a cada criança de forma particular; e que o que planejamos está sempre em movimento de acordo com a imprevisibilidade contida nas relações educativas e nas pessoas que nela estão envolvidas.

Da imprevisibilidade advém a diferença fundamental entre fabricar e agir: o futuro não é a materialização de uma obra concebida em nossas mentes, mas imprevisível pela possibilidade da ação. Na atividade da fabricação temos um fim (enquanto finalidade e final), não a ação. O curso das histórias humanas não tem um fim a ser atingido: um resultado que se possa pretender obter e que seja conclusivo. O futuro não deriva de um plano para as crianças, mas da possibilidade ontologicamente radicada na natalidade, no advento do inesperado. Segundo Arendt, é um erro para a política esperar que o convencimento dos jovens através da educação altere o curso do mundo, pois isso pretende esvaziar a condição de liberdade dos homens, afinal "preparar uma nova geração para um mundo novo só pode significar o desejo de arrancar das mãos dos recém-chegados sua própria oportunidade face ao novo" (ARENDT, 2005b, p. 226).

Além disso, a repetição ou a mera instituição de algo velho que não ecoa mais sentido compromete não apenas a existência do mundo, mas também com esta o sentido de nossa própria existência: afinal não existe mundo sem homem e homem sem mundo. Isso significa oferecer sentido à pergunta: que homem restará se o mundo deixar de existir? Os homens, que são potencialmente livres, devem manter a possibilidade da experiência da própria liberdade: esse é o sentido da política. Portanto, na crença de que por meio da educação somos capazes de transformar o mundo, já que através dela ditamos o futuro, está a incredulidade na liberdade dos homens.

Assim, a expectativa da criação de uma nova ordem política lançada às novas gerações por meio da educação retira da própria política seu sentido no presente e suas possibilidades para com o mundo. É como se nos sentíssemos no direito de abandonar as questões do mundo e pudéssemos esperar que alguém, um dia, as resolva por nós. Ou, então, quando, ao nos esforçarmos por ditar e determinar uma realidade futura, o que de fato acontece é a tentativa de retiramos dos novos sua própria possibilidade de renovação do mundo em seu tempo. É fundamental considerarmos que o olhar de Arendt não está voltado ao futuro - embora nele 
também deva estar preservada a possibilidade do novo -, mas a responsabilidade se encontra no tempo presente, a cada segundo, pois qualquer mudança no curso do mundo se dá através da política. É nela que os homens confrontam seus pensamentos e julgamentos por meio do discurso e renovam o mundo por meio da ação.

Porém, já que a educação e a política existem no mundo - e a partir dele -, elas têm em si uma responsabilidade perante sua continuidade. A responsabilidade presente na educação para com ele se realiza pela conservação do que nos oferece estabilidade, e na política pela renovação: portanto, a educação não é um âmbito transformador. Afinal, na educação estamos lidando com crianças e é sobre os ombros dos adultos que recai, no pensamento de Arendt, qualquer responsabilidade: tanto na educação quanto na política.

Embora não sejamos capazes de definir uma configuração precisa para o mundo por meio da educação, é claro que esta tem consequências. Admitir tal fato não nos isenta de reconhecer os limites da tarefa educativa, pois o ponto central aqui é aceitar a imprevisibilidade nela contida. $\mathrm{O}$ mundo no qual nos movemos hoje não está intacto, e essa crise que atinge o mundo moderno atinge também a educação. Se nosso mundo não é mais sustentado por uma tradição capaz de guiar nossas ações, muitas vezes o que mais nos afeta ao educar está mais próximo do desalento do que da referência de um mundo coeso em princípios e fundamentos, seja ele existente ou sonhado. No entanto, vale perguntar: será que alguém é capaz de educar sem ter um ideal de mundo permeando e oferecendo sentido à sua atuação?

Se optarmos por responder negativamente a essa questão, assumindo que educamos sempre pretendendo a preservação de uma realidade ou sua transformação, devemos ao menos reconhecer a imprevisibilidade contida nessa tarefa, tendo em conta que seus alcances não são nunca antecipadamente garantidos (o que podemos considerar de grande sorte, afinal seria terrível imaginar que a ideologia totalitária presente na educação alemã nazista teria sido capaz de viabilizar a concretização dessa realidade para aquela nação por mais tempo).

Em contrapartida, se respondermos positivamente àquela questão, devemos assumir que para educar é preciso ao menos termos em mente o mundo que não queremos, isto é, o que buscamos negar e não queremos manter como realidade entre nós. Portanto, ao realizarmos a tarefa educativa, não somos capazes de deixar de comunicar a perplexidade que muitas vezes nos domina, afinal frequentemente os fatos do mundo no qual hoje nos movemos nos deixam atônitos e, literalmente, sem ação. 
A reflexão sobre a responsabilidade pelo mundo que deriva da natalidade nos conduz a uma relação entre a educação e a política que amplia nossa compreensão sobre as afirmações de separação radical entre esses dois âmbitos encontradas tanto em Reflexões sobre Little Rock quanto em A Crise na Educação. No entanto, é exatamente a condição de separação que Arendt estabelece entre a educação e a política que possibilita a relação entre elas até aqui estabelecida. Se entregamos a responsabilidade política para a educação, esvaziamos a própria política. Portanto, é apenas mantendo o devido distanciamento entre elas que a educação preserva a possibilidade da ação na política no presente e também no futuro. Essa separação revela uma distinção entre a educação e a política pelo fato de elas não terem suas responsabilidades confundidas no pensamento de Arendt (embora ambas sejam responsabilidades pelo mundo). Encontramos, assim, a distinção existente entre o que é prépolítico (nesse caso, a educação) e a própria política. No entanto, o que verificamos é que a distinção estabelecida por Arendt é a maneira de relacionar os dois âmbitos a partir de seu pensamento.

No ensaio crítico Poder e violência no pensamento político de Hannah Arendt: uma reconsideração, André Duarte (2009, p. 134) afirma que a relação estabelecida a partir da distinção entre as categorias conceituais de Arendt está presente em todo o seu pensamento, pois elas sempre são entendidas uma a partir da outra:

[...] é preciso caracterizar as inúmeras distinções conceituais propostas por Arendt ao longo de sua obra, pensando-as sempre em seu caráter relacional, isto é, sob a pressuposição de que aquilo de que se distingue mantém uma relação intrínseca com aquilo de que se distingue, jamais podendo existir como entidade isolada e absoluta, independentemente de seu outro [...].

Todo o pensamento de Arendt consiste em distinguir conceitos e pensar a experiência a partir da distinção. Exemplos típicos de separações conceituais em sua obra são as três atividades humanas, as esferas pública e privada, a liberdade e a necessidade, a pluralidade e o isolamento, o poder e a violência. Os diferentes elementos que compõem esses grupos ou pares conceituais estabelecem maneiras próprias de se relacionarem entre si, não nos permitindo enquadrar essas relações numa única fórmula. No entanto, sem sombra de dúvida, um deve ser pensado a partir das distinções que estabelece com o outro. Embora a distinção 
seja o fundamento da reflexão, compreendê-las de maneira estanque é reduzir sua capacidade iluminadora. Portanto, pensá-las isoladamente, sem a luz que a outra oferece e que complementa seu sentido, limita a compreensão do fenômeno, assim como pensar a educação em Arendt independente de seu entendimento sobre a política. Nesse sentido, Duarte (2009, p. 135) afirma:

\footnotetext{
A fim de exemplificar o caráter relacional das distinções arendtianas, podemos pensar a instituição de uma fronteira não apenas como o traçado do limite que separa suas entidades, mas também e, sobretudo, unifica-as: todo limite estabelece uma partilha ao mesmo tempo em que vincula os opostos que aí se separam, os quais compartilham o limite e se unificam justamente ali onde se separam.
}

Arendt se utiliza do exemplo de uma mesa para explicar o conceito de mundo. Ao mesmo tempo em que os homens que estão ao seu redor são separados por ela, estão também reunidos. O que André Duarte nos apresenta é que uma situação como essa se dá também entre os conceitos arendtianos: o próprio limite, ao separar, relaciona, e o desafio está em compreendermos como essa relação é possível em cada caso particular.

Entre a educação e a política é de fato isso o que parece acontecer: quando elas se separam a relação se estabelece. A relevância dessa reflexão está em gerar uma perspectiva absolutamente diferente dos discursos correntes sobre a educação, permitindo que a pensemos em relação à política, mas não confundida com ela: e "[...] de fato, só faz sentido estabelecer distinções para aquilo que se apresenta de maneira intrinsecamente confusa e misturada no mundo político" (DUARTE, 2009, p. 135). Essencialmente a distinção permite que não confundamos, substituamos um pelo outro, ou ainda igualemos âmbitos que assumem significados distintos: essa separação é a forma de tanto a educação quanto a política preservarem a si mesmas e também suas relações. Qualquer dessas opções supõe reduzir o significado da política e exacerbar a capacidade de alcance da educação.

Quando algo está misturado a outro, ambos são vistos como uma mesma coisa e dessa forma não podem se relacionar: a distinção e a separação são o que permite que seja criado o espaço para a relação. Segundo André Duarte (2009, p. 136), apesar das distinções conceituais, Arendt reconhece que essas categorias não existem no mundo de maneira compartimentada. No entanto, o que vale compreendermos é que a separação permite 
desanuviar o que está obscuro no mundo, permitindo relações até mesmo inusitadas. Nossa reflexão, que até então preserva a distinção entre a educação e a política, encontra na responsabilidade pela continuidade do mundo consequente da natalidade uma relação possível.

Reconhecido o fato de que a própria distinção permite que sejam estabelecidas relações entre a educação e a política, vale nos perguntarmos se a relação de antecedência necessária encontrada entre as experiências pré-políticas da polis e a política também é válida no que se refere à educação. Do ponto de vista da pessoa individual, a relação de simples antecedência existe, pois aquele que chega ao mundo, antes de participar da política como adulto, passa por experiências educativas até o momento de assumir a responsabilidade pelo mundo junto a seus iguais. Encontramos essa mesma condição de antecedência quando nos referimos à escola propriamente dita como um âmbito que representa a transição entre o lar e o mundo. No entanto, vale nos perguntarmos se sobre essa relação de antecedência recai também o peso da necessidade.

A relação de antecedência necessária, além de ter sido identificada nas situações prépolíticas da Antiguidade Grega da polis sobre as quais refletimos, também está expressa numa única passagem a respeito da educação. Encontramos o trecho em questão em Que é autoridade?, em meio a algumas das considerações de Arendt sobre a crise da própria autoridade. Para compreendermos tal afirmação devemos considerar o que até então já refletimos neste trabalho.

\footnotetext{
O sintoma mais significativo da crise, a indicar sua profundeza e seriedade, é ter ela se espalhado em áreas pré-políticas tais como a criação dos filhos e a educação, onde a autoridade no sentido mais lato sempre fora aceita como uma necessidade natural, requerida obviamente por necessidades naturais, o desamparo da criança, como por necessidade política, a continuidade de uma civilização estabelecida que somente pode ser garantida se os que são recém-chegados por nascimento forem guiados através de um mundo preestabelecido no qual nasceram como estrangeiros (ARENDT, 2005b, p. 128, grifo nosso).
}

Da mesma maneira que Arendt reconhecia que no caso da polis grega as relações desiguais entre senhores e escravos eram entendidas como necessárias para a preservação do espaço político, neste trecho ela reconhece que a autoridade dos adultos na educação, além de 
uma necessidade natural, é uma necessidade política. Mas o que a torna uma necessidade política? Arendt (2005b, p. 128) afirma, em seguida, que a necessidade política é a “continuidade de uma civilização estabelecida que só pode ser garantida se os que são recémchegados por nascimento forem guiados através de um mundo preestabelecido no qual nascem como estrangeiros". Isso significa que a própria educação (entendida como uma forma de preservar o mundo) é uma necessidade política.

Se colocássemos essa afirmação lado a lado com as proposições de separação radical entre a educação e a política, sem realizarmos uma reflexão mais detida sobre essa relação a partir de outros conceitos, ela facilmente pareceria um contrassenso. No entanto, as reflexões sobre a natalidade como conceito comum à educação e à política e sobre a responsabilidade pelo mundo presente nos dois âmbitos nos permitem admitir essa condição de antecedência necessária que a educação assume em relação à política, estabelecida a partir de sua distinção.

Evidentemente, tal condição diz respeito ao papel da educação diante da preservação do mundo, conforme está expresso no próprio trecho citado. A educação, ao comunicar o mundo aos jovens, pretende gerar neles o pertencimento ao mundo necessário para a participação e responsabilidade política. Além disso, vimos que nenhuma ação se dá sem fundamentos, sem um mundo no qual encontramos algum sentido para nossa existência comum ou, em tempos de crise, sem um mundo ao qual possamos nos contrapor por meio da ação para renová-lo, ou ainda onde se possa encontrar alguma experiência esquecida que empreste um novo sentido às nossas experiências. Por fim, a apresentação do mundo também favorece a existência de algo comum entre aqueles que são educados, algo que tenha a capacidade de reuni-los.

No entanto, como vimos, a educação tem uma dupla responsabilidade, ou seja, não apenas a de preservar o mundo, mas também a de preservar os novos. Pensar a educação sem essa outra responsabilidade faz com que ela se descaracterize por completo, pois seria lançar as crianças ao mundo propriamente dito, sem criarmos para elas um tempo e um espaço de proteção, de resguardo, onde tudo que do mundo lhes é oferecido é feito na medida de suas possibilidades. Essa outra responsabilidade da educação (que Arendt não menciona ao afirmar que a educação é uma necessidade política) também pode ser entendida como pré-política, afinal, além de preservar a possibilidade da pluralidade sobre a qual se fundamenta a política, preserva também a possibilidade da liberdade, pois "a própria liberdade da espontaneidade é, por assim dizer pré-política, (...) sem ela toda a liberdade política perderia seu melhor e mais profundo sentido; (...) em última análise, ela nasce do indivíduo (...)” (ARENDT, 2007, p. 59). 
Se a liberdade só existe enquanto fenômeno político, a condição que a antecede, a espontaneidade, se manifesta com cada homem único. A espontaneidade da criança é, então, a manifestação mais pura de sua condição singular. No entanto, a espontaneidade só pode ser preservada pela educação se compreendermos que ela é um âmbito distinto da política e sobre o qual, portanto, não podemos depositar expectativas de renovação do mundo. Caso contrário, as possíveis tentativas de determinação de alguma situação de mundo (que decorrem da confusão entre a educação e a política) podem comprometer a condição de promessa de ação que se torna sempre presente com a natalidade.

Exatamente em benefício daquilo que é novo e revolucionário em cada criança é que a educação precisa ser conservadora; ela deve preservar essa novidade e introduzi-la como algo novo em um mundo velho que, por mais revolucionário que possa ser em suas ações, é sempre, do ponto de vista da geração seguinte, obsoleto e rente à destruição (ARENDT, 2005b, p. 242).

Só assim a singularidade de cada homem, que representa um início, também se mostra uma condição pré-política, afinal o fato de que "toda vida individual, compreendida entre o nascimento e a morte, pode vir a ser narrada como uma história com princípio e fim, é a condição pré-política e pré-histórica da História [...]” (ARENDT, 2005a, p. 197). Essa condição singular (e que é pré-política), reunida no mundo, fundamenta a política e é a base da ação. Por fim, ao se referir à liberdade, que é o sentido da política, Arendt parece esclarecer algo que encontramos na relação entre o que é pré-político e a própria política.

\footnotetext{
Essa liberdade de movimento, seja a liberdade de ir em frente e começar algo novo e inaudito, ou seja a liberdade de se relacionar com muitos conversando e tomar conhecimento de muitas coisas que, em sua totalidade, são o mundo em dado momento, não era nem é, de maneira alguma, o objetivo da política - aquilo que seria alcançável por meios políticos; é muito mais o conteúdo e sentido original da própria coisa política. Nesse sentido, política e liberdade são idênticas e sempre onde não existe essa espécie de liberdade, tampouco existe o espaço político no verdadeiro sentido. Por outro lado, os meios com os quais se pode fundar esse espaço político e proteger sua existência não são, de modo algum, sempre e necessariamente meios políticos (ARENDT, 2007, p. 60).
}

Arendt, então, reconhece no trecho final dessa citação o que antes apontamos a respeito da política: que ela depende, para existir e se preservar, de condições que lhe são anteriores (e que são distintas dela). Nesse sentido a educação assume sua condição de âmbito 
pré-político, e a partir dessa constatação podemos compreender as relações entre ela e a política que emergem de maneira pouco evidente em seus escritos.

O papel da educação, portanto, está em apresentar o mundo aos jovens e manter a abertura para a possibilidade da ação na política. Por isso, sua forma de se realizar é através da preservação do mundo que existe entre nós toda vez que o comunicamos aos nossos jovens. Sua outra responsabilidade de preservação é para com os novos: essas crianças que chegam a nós pelo nascimento precisam manter-se preservadas de tudo o que coloca em risco tanto seu desenvolvimento quanto sua condição de novidade. Pois,

O milagre que salva o mundo, a esfera dos negócios humanos, de sua ruína normal e 'natural' é, em última análise, o fato do nascimento, no qual a faculdade de agir se radica ontologicamente. Em outras palavras, é o nascimento de novos seres humanos e o novo começo, a ação de que são capazes em virtude de terem nascido. Só o pleno exercício dessa capacidade pode conferir aos negócios humanos fé e esperança [...]. Essa fé e esta esperança no mundo talvez nunca tenham sido expressas de modo tão sucinto e glorioso como nas breves palavras com as quais os Evangelhos anunciaram a 'boa nova': 'Nasceu uma criança entre nós' (ARENDT, 2005a, p. 259). 


\section{A CRISE NA EDUCAÇÃO, UM PROBLEMA POLÍTICO}

\subsection{A crise do mundo moderno e a ausência de mundo}

Consideramos até o momento que, embora Arendt tenha afirmado uma separação radical entre os âmbitos da educação e da política, o conceito de natalidade estabelece uma das relações entre elas e que a responsabilidade pelo mundo é algo comum a ambas (embora se realize de maneira distinta e complementar). Entretanto, se estamos nos referindo a âmbitos que têm como centro o mundo, devemos compreender minimamente qual é a situação em que ele se encontra. Encontramos publicado como epílogo de A Promessa da Política um pequeno texto de Hannah Arendt (2008) que corresponde à conclusão de um de seus cursos de teoria política. Sua introdução contém a imagem que ela considera expressar a situação de nosso mundo depois dos fenômenos totalitários: "o moderno crescimento da ausência-de-mundo, a destruição de tudo que há entre nós, pode ser também descrito como a expansão do deserto" (ARENDT, 2008, p. 266).

A condição da existência dos homens no mundo moderno em crise é, na realidade, a de um não-mundo: não há estabelecido entre nós algo claro e forte que nos comunique e seja capaz de nos unir enquanto comunidade, não há estabilidade que nos ofereça segurança e fundamente nossas relações entre nós e para com o mundo. É como se, apesar de reunidos num mesmo espaço, estivéssemos todos soltos e distantes uns dos outros em meio a um imenso deserto. $\mathrm{O}$ vazio que observamos entre nós invade nossa própria existência. $\mathrm{O}$ vento carrega a areia e conforma a cada momento uma nova paisagem, e a rapidez desse movimento é tão avassaladora que não temos tempo de nos reconhecermos nesse ambiente. Que referências têm os homens num espaço como esse para existir? Sobre o que podem falar e o que podem compartilhar? Em torno de que se reúnem esses homens isolados? O que entregamos como herança às crianças que nascem sob tais condições? Portanto, o deserto representa o resultado da moderna perda do mundo.

Os escritos de Arendt sempre partem de eventos do mundo que denunciam seu estado 
de crise e revelam a presença e expansão dessa condição de deserto. Infelizmente, nesses fenômenos somos capazes de identificar mais facilmente o caminho da ruína do que as possibilidades de ação. Trata-se de experiências que comumente apontam para a negação constante do amor mundi a que Arendt se refere. Dentre elas podemos mencionar a destruição de comunidades políticas por meio de guerras que são fruto da intolerância; a derrota do uso da palavra como mediadora de conflitos, criando e mantendo tensões; o consumo como forma de nos relacionarmos com o mundo e destruí-lo; a perda da valorização do que é público; e tantas outras experiências que revelam não só a crise do mundo, mas também o que Arendt considera expressar a aproximação do fim ou do desaparecimento da própria política.

Sem qualquer intenção de restaurar o passado ou encontrar respostas para as questões - mas sim compreender o que a inquieta -, Arendt ilumina essas experiências apontando para a perda de alguns dos fundamentos que sustentavam nosso mundo comum. Seu pensamento se dá a partir da perplexidade causada pela crise e, embora siga de forma tão drástica quanto os fatos, volta-se para a esperança contida na ação livre e inesperada que pode fundar o novo, e nas capacidades humanas de pensar e julgar.

Se a crise a que nos referimos é uma crise do mundo, não há como deixarmos de refletir sobre suas implicações políticas e educativas. Se considerarmos que a política e a educação, além de serem instituições do mundo, são condicionadas por ele, qualquer situação que o atinge tem efeito sobre elas. Por isso, Arendt introduz A Crise na Educação fazendo referência a seu contexto, a crise no mundo moderno, e, em seguida, afirma que a situação da educação é um problema político dos mais relevantes.

\footnotetext{
A crise geral que acometeu o mundo moderno [...] se manifesta diversamente em cada país, envolvendo áreas e assumindo formas diversas. Na América, um de seus aspectos mais característicos e sugestivos é a crise periódica na educação, que se tornou, no transcurso da última década pelo menos, um problema político de primeira grandeza (ARENDT, 2005b, p. 221).
}

Ainda na introdução do mesmo ensaio, Arendt compara a crise na educação às situações políticas mais impactantes do século XX, reforçando a ideia anterior de que ela é, de fato, uma questão política. Além disso, o alcance mundial da crise na educação (que não está confinada às fronteiras nacionais norte-americanas e por isso não pode ser considerada 
exclusiva desse país) evidencia ainda mais sua relação com a crise geral presente no mundo moderno.

[...] se compararmos essa crise na educação com as experiências políticas de outros países no século XX, com a agitação revolucionária que se sucedeu à Primeira Guerra Mundial, com os campos de concentração e de extermínio, ou mesmo com o profundo mal-estar que, não obstante as aparências contrárias de propriedade, se espalhou por toda a Europa a partir do término da Segunda Guerra Mundial, é um tanto difícil dar a uma crise na educação a seriedade devida. É de fato tentador considerá-la como um fenômeno local e sem conexão com as questões principais do século, pelo qual se deveriam responsabilizar determinadas peculiaridades da vida nos Estados Unidos que não encontrariam provavelmente contrapartida nas demais partes do mundo. Se isso fosse verdadeiro, contudo, a crise em nosso sistema escolar não se teria tornado um problema político e as autoridades educacionais não teriam sido incapazes de lidar com ela a tempo (ARENDT, 2005b, p. 222).

Essas afirmações de Arendt suscitam algumas questões: como pode a crise da educação ser um problema político se educação e política são âmbitos distintos e separados? O que isso pode nos revelar sobre a relação entre a educação e a política a partir de seu pensamento? A leitura dos trechos acima citados nos conduz imediatamente à compreensão de que a razão fundamental de a crise na educação ser um problema político é o fato de ela ser consequência de uma crise maior e mais profunda: a crise que atinge o mundo moderno, nos permitindo reconhecer na situação enfrentada pela educação suas conexões com as principais questões do século XX.

Uma crise, segundo Arendt, acontece quando deixamos de compartilhar conceitos e práticas capazes de fundamentar nossas relações e ações no mundo, ou ainda quando perdemos a referência de experiências que guiem ou inspirem nossa existência comum. Com uma crise "[...] perdemos as respostas em que nos apoiávamos de ordinário sem querer perceber que originalmente elas constituíam respostas às questões" (ARENDT, 2005b, p. 223). Consequentemente, deixamos de ter parâmetros e critérios que, por serem comuns, guiavam nosso pensar, julgar e agir: perdemos a estabilidade que sustentava a relação dos homens entre si e deles para com o próprio mundo. Para Arendt (2005b, p. 227), o que de fato acontece com uma crise é o desmoronamento de parte do mundo. 
No caso do mundo moderno, esse desmoronamento apresenta diferentes manifestações, e dentre as mais relevantes podemos mencionar: a valorização da vida como bem supremo em detrimento do mundo; a emergência da esfera social como resultado da diluição das fronteiras entre as esferas pública e privada; a crise da tradição e da autoridade; o consumo regendo a relação dos homens com o mundo, representando o triunfo do animal laborans; a sociedade de massas; a substituição da ação pelo comportamento; e outras. Essas manifestações atingem a educação, fazendo com que sua crise seja decorrência do que se passa com o mundo e também com a política.

Apesar de não ser possível apresentarmos todos os aspectos da crise a que Arendt se refere, nos interessa refletir minimamente sobre seu significado para que possamos compreender as razões de a crise na educação ser um problema político e não simplesmente pedagógico e interno ao campo. Por termos nos referido até então ao mundo como condição tanto da política quanto da educação, refletiremos brevemente sobre como se dá na modernidade a perda de um mundo comum capaz de nos reunir e oferecer significado compartilhado para as experiências humanas. Para isso consideraremos apenas alguns dos traços gerais dessa crise que resultaram na situação de desertificação em que o mundo moderno se encontra.

Embora Arendt não considere que as várias manifestações da crise sejam desdobramentos necessários dos eventos que forneceram condições para o estabelecimento da Era Moderna, ela encontra entre ambos profundas relações, afinal foram tais eventos que transformaram nossas relações com o mundo. Essas diferentes facetas da crise estabelecem fortes relações entre si, muitas vezes intensificando seus desdobramentos ou ainda gerando elementos novos. Apesar de a reflexão sobre a crise estar presente em toda a sua obra como um fio condutor a partir do qual se dá seu pensamento, é em A Condição Humana que são apresentadas as relações entre os fatos que permitiram o desenrolar da modernidade e as manifestações da crise, dentre elas a ascensão do social. No entanto, é no ensaio sobre a crise na cultura ${ }^{23}$ (2005b), contido na obra Entre o Passado e o Futuro, que encontramos a descrição de uma cena capaz de expressar parte essencial do significado do social, além de sua localização como um fenômeno moderno.

A 'boa sociedade', na forma em que a conhecemos nos séculos XVIII e XIX,

23 Cf. ARENDT, 2005b, capítulo A Crise na Cultura: sua importância social e política, p. 248-281. 
originou-se provavelmente das cortes europeias do período absolutista, e sobretudo da corte de Luís XIV, que soube reduzir tão bem a nobreza da França à insignificância política mediante o simples expediente de reuni-los em Versalhes, transformá-los em cortesãos e fazê-los se entreter mutuamente com intrigas, tramas e bisbilhotices intermináveis engendradas inevitavelmente por essa perpétua festa (ARENDT, 2005b, p. 251).

Os salões de alta sociedade das monarquias absolutistas no século XVIII expressam o que significou a ascensão do social no cenário político e moderno da época. O modo de funcionamento e administração familiar foi adotado para a condução das questões públicas dos Estados Nacionais, a partir de sua centralização numa única figura com características patriarcais: o monarca. A atitude do rei mostra-se análoga a de um chefe de uma grande família. Além disso, a corte passa a dedicar sua atenção aos assuntos da vida privada, esvaziando sua condição de atores políticos. A esfera social, portanto, é representada pela intrusão dos métodos de condução, temas e atividades da vida privada no âmbito público e político.

Embora a realidade histórica do mundo ocidental em nossos tempos seja bastante diferente da que existia nas primeiras épocas da conformação da sociedade, nossa forma de condução dos assuntos políticos se dá de forma administrativa e burocrática (como se quem governa fosse um administrador de uma empresa familiar pela qual se coloca como figura temporariamente responsável). Identificamos prioritariamente a política com o mero cumprimento de tarefas para o suprimento de necessidades vitais e de consumo e não reconhecemos nela o âmbito no qual os homens discutem sob diferentes pontos de vista os assuntos relativos ao mundo que compartilham, e na qual buscam as melhores respostas para suas questões por meio da argumentação persuasiva e da participação.

A ascensão da esfera social advém da perda dos limites entre a esfera privada (que atende ao domínio da vida e ao cumprimento das tarefas que suprem a necessidade) e a esfera pública (que reúne os homens em sua pluralidade e partilha do mundo), significando o resultado da dissolução de uma na outra. A dificuldade que encontramos em distinguir em nosso mundo o que Arendt considera próprio a cada uma dessas esferas decorre da perda gradativa desse limite que as separava. Consequentemente, podemos observar que a esfera social tem se caracterizado pela visibilidade de temas antes ocultados, pela tendência à valorização de tudo que se refere à vida e por uma forma de conduzir o que é público como se 
fosse familiar (e o que é familiar como se fosse público). Essa confusão entre as esferas permitiu intensificar a ascensão do valor da vida individual em detrimento do valor que atribuímos às questões públicas, que dizem respeito ao mundo comum de uma determinada comunidade.

A principal dimensão política da dissolução dessa fronteira está na perda de sentido do público. Sem um espaço público definido fica comprometida a possibilidade de ação, afinal, para que ela aconteça, depende de que os homens estejam reunidos em sua pluralidade e que a razão dessa reunião sejam os assuntos humanos (que, por serem comuns, alcançam a visibilidade conferida pela esfera pública). Vera da S. Telles (1990), em seu ensaio Espaço público e espaço privado na constituição do social, considera os diferentes desdobramentos da ascensão da esfera social para a política e aponta para o que significa a perda do espaço público.

[...] a perda do espaço público significa a privação de um mundo compartilhado de significações e a partir do qual a ação e a palavra de cada um podem ser reconhecidas como algo dotado de sentido e eficácia na construção de uma história comum. [...] Finalmente, a perda do espaço público significa, agora num registro explicitamente político, a perda de um espaço reconhecido de ação e opinião, o que significa dizer, a perda da liberdade que exige, para sua efetivação, um espaço politicamente organizado (TELLES, 1990, p. 3).

A perda da liberdade, que se revela no decréscimo progressivo de um espaço para a ação, compromete a visibilidade da condição plural dos homens. Se na ação e no discurso está a possibilidade da manifestação da singularidade, num espaço no qual a vida foi elevada à razão de ser de nossa convivência não há como haver distinção: o que nos resta é a repetição imposta pela necessidade. Além disso, a reunião dos homens num grande grupo social exige que se comportem como se fossem membros de uma grande família. Um fato que exemplifica essa situação (e ao qual Arendt faz referência) é o uso da estatística como recurso de identificação da 'vontade' social, negando a pluralidade nela contida. A simples enumeração de pareceres, além da tentativa de reuni-los no menor número possível de variáveis, evidencia a situação em que a pluralidade se encontra. Portanto, com o advento da sociedade, a singularidade - e, portanto, a pluralidade dos homens no mundo, que é condição da política se dilui numa coletividade de homens que se não se distinguem.

Como consequência da perda de um espaço público e, portanto, do espaço de ação, 
temos o fato de as relações entre os homens - e deles para com o mundo - passarem a se realizar a partir das regras de comportamento ${ }^{24}$ : comportar-se significa fazer o que dita um padrão social. Essa padronização homogeneíza os homens e não pode ser confundida com a igualdade política na medida em que se opõe a ela, afinal representa a conformação das atitudes dos homens de acordo com os padrões estabelecidos. A igualdade, para Arendt, tem a pluralidade como conceito constitutivo. A partir dessa condição, acordada entre os homens pela política, os homens plurais são capazes de se reunir para discutir e conduzir os temas do mundo relativos à sua existência comum. Essa igualdade, que é definida artificialmente, distribui a possibilidade de participação política. Nesse sentido, Arendt toma como experiência elucidativa a polis grega, na qual identifica a igualdade e a pluralidade como condições da reunião dos homens na ágora: nesse espaço todos eram igualmente cidadãos, e o que estava em jogo, de fato, era a aparição da singularidade por meio de suas ações e palavras. O olhar dos homens sob o prisma da igualdade política oferecia a cada um seu próprio lugar, voz e movimento: estabelecia um direito.

Porém, com a padronização do comportamento, o que acontece é o contrário da igualdade política assim entendida, afinal ela significa a eliminação das diferenças, do ineditismo que cada um de nós representa no mundo. O comportamento, assim como o labor, é caracterizado pelo automatismo (que é o oposto da novidade da ação singular). Nisso está a limitação que nos oferece o comportamento enquanto mediador das relações políticas. Portanto, com a ascensão do social nos resta a repetição e não mais o ineditismo da ação.

Essa situação, essencialmente moderna, vem marcando profundamente as relações políticas dos homens no mundo e se intensificando cada vez mais. Arendt considera que a sociedade, que ascendeu nos séculos XVIII e XIX, se expandiu e que outros desdobramentos podem hoje ser observados. Essa expansão se traduz na conformação de uma sociedade de massas: com ela os homens passam a ser tratados como um único bloco indistinto. Arendt (2005b) afirma que, se em outras sociedades diferentes grupos sociais se distinguiam entre si a partir de códigos de comportamento próprios e interesses, na sociedade de massas o fenômeno da padronização é ainda maior. Isso significa apenas que a sociedade de massas é o

${ }^{24}$ O que Arendt chama de regra de comportamento nada tem a ver com lei. No pensamento de Arendt, a lei é entendida como um fundamento para as relações políticas, advinda de um acordo entre os homens. Sua maneira de entendê-la está bastante relacionada à experiência da elaboração de leis na República Romana, embora também reflita sobre seu significado para a conformação das polis gregas (apesar de, nesse contexto, ela não ser elaborada a partir de relações políticas, mas surgir como produto da atividade da fabricação). Encontramos uma reflexão a esse respeito em $O$ que é política?. Sobre a lei romana Arendt (2007, p. 112) afirma: "[...] uma lei é algo que liga os homens entre si e se realiza não através de um ato de força ou de um ditado, mas sim através de um arranjo ou um acordo mútuo". 
mesmo fenômeno da sociedade propriamente dita, mas manifesta de maneira acentuada e totalitária (entendida em sua abrangência): "o surgimento da sociedade de massas [...] indica apenas que os vários grupos sociais foram absorvidos por uma sociedade única, tal como as unidades familiares haviam antes sido absorvidas por grupos sociais" (ARENDT, 2005b, p. $50)$.

Uma diferença presente entre as sociedades anteriores e a sociedade de massas está nas condições e possibilidades de os homens dela escaparem. Em A crise na cultura: sua importância social e política, Arendt (2005b) lembra que, nos primeiros estágios da conformação da sociedade, aqueles que dela não queriam fazer parte podiam aderir a outros grupos (o que comumente se dava com os que se vinculavam aos partidos revolucionários). No caso da sociedade de massas os caminhos de escape são ainda mais limitados, já que a grande maioria dos grupos da população foi assimilada por ela. Na massa a pluralidade se dissolve enquanto realidade presente e ativa, fenômeno que pôde ser observado fortemente nas sociedades totalitárias, nas quais o que existia era a absoluta repetição de homens que se comportavam de maneira indistinta e que assim foram facilmente conduzidos.

Outra característica essencial da sociedade de massas, segundo Arendt, é o fato de ela estar composta fundamentalmente por consumidores. Com o lugar de centralidade que a preocupação com a vida passa a ocupar na esfera pública (que assim se descaracteriza) e a repetição pelo comportamento, as condições próprias do labor passaram a reger as relações dos homens com o mundo e a necessidade passou a imperar. Se o labor se relaciona com seus produtos de forma a consumi-los para que o ciclo vital se mantenha, na sociedade de massas os homens estabelecem uma relação de consumo para com o mundo: tudo está imerso no ciclo repetitivo da vida, que termina fatalmente em destruição se não houver a interrupção pelo milagre da ação humana. O consumo é traço fundamental da sociedade na qual nos movemos e se traduz no que Arendt (2005a) chama de 'a vitória do animal laborans'. A partir dessa relação de consumo, o mundo perde sua estabilidade - e nós a segurança de nos movermos nele: nada mais permanece, tudo está em movimento e sendo descartado e substituído a todo momento.

Segundo Arendt, compomos uma sociedade de detentores de emprego e de assalariados, o que significa que nossas ocupações são concebidas apenas como uma forma de manter a vida, ou seja, de conquistarmos recursos para nosso sustento, consumo e entretenimento $^{25}$. Trata-se de uma condição marcada pela necessidade (seja ela imposta pela com a cultura e a diferencia do que é o entretenimento. A diversão, além de ser considerada por ela como 
natureza ou pelo próprio âmbito da fabricação e do comércio): essa é a razão que move cada um de nós para as nossas rotinas de trabalho (e o salário é tão cíclico e repetitivo quanto o labor). Com isso, além das esferas pública e privada, as atividades humanas também se descaracterizaram em seus aspectos mais fundamentais. A ação está comprometida em decorrência da ascensão da esfera social, afinal o que marca nossos movimentos e relações no mundo é o comportamento, e não a liberdade da ação. Mas, além disso, também a fabricação perdeu seu sentido de produção de um mundo de relativa permanência capaz de nos conferir estabilidade, pois o mundo moderno passou a ser regido pelas condições do labor: a vida, e não o mundo, move sua realização. As condições da vida natural invadem e a necessidade e a repetição imperam.

Assim, a fabricação, que antes deixava no mundo produtos duráveis que nos ligavam aos que aqui estiveram e aos que um dia estarão, passa a produzir objetos de consumo. Estes são fabricados para que sejam substituídos, afinal só com o consumo se mantém a condição necessária da reposição constante. Desaparece a estabilidade e se estabelece um movimento incessante, ritmo que caracteriza essencialmente o labor. Por isso nos tornamos não só uma sociedade de massas, mas também uma sociedade de consumidores: em vez de usarmos os objetos resultantes da fabricação, passamos a consumi-los exatamente como acontece no labor (e consumo, como vimos, é sinônimo de destruição).

Vimos que com a conformação da esfera social houve a entrada dos temas e formas de administração da esfera privada na esfera pública, e que a vitória do animal laborans se expressa no fato de os homens terem passado a desenvolver suas atividades com o mesmo funcionamento do labor. Mas o que há em comum entre o social e o labor? Seu motivo central: a vida. Não sem razão, Arendt afirma que a vida é o bem supremo em nossos tempos. Segundo seu pensamento, o fenômeno de elevação da vida a essa categoria de valorização é bastante anterior à ascensão do social e está relacionada à projeção do cristianismo depois de Paulo.

O motivo pelo qual a vida se afirmou como ponto último de referência na era moderna e permaneceu como bem supremo para a sociedade foi que a moderna inversão de posições ocorreu dentro da textura de uma sociedade cristã, cuja crença fundamental na sacrossantidade da vida sobrevivera à secularização e ao declínio geral da fé cristã, que nem mesmo chegaram a abalá-la. Em outras palavras, a

uma necessidade, é algo a ser consumido pelos homens. "A verdade é que todos nós precisamos de entretenimento e diversão de alguma forma, visto que somos sujeitos ao grande ciclo vital" (ARENDT, 2005b, 257). 
moderna inversão imitou, sem questionar, a mais significativa viravolta com a qual o cristianismo irrompera no cenário do mundo antigo, viravolta politicamente mais importante e, pelo menos, historicamente, mais duradoura que qualquer conteúdo dogmático ou crença específica. Pois a 'boa nova' cristã da imortalidade da vida humana individual invertera a antiga relação entre o homem e o mundo, promovendo aquilo que era mais mortal, a vida humana, à posição de imortalidade ocupada até então pelo cosmos (ARENDT, 2005a, p. 327).

Para compreendermos essa afirmação, devemos recorrer à distinção entre a imortalidade presente na Antiguidade Grega e a transformação desse conceito com o cristianismo (apresentada em A Condição Humana). Na Grécia Antiga os homens - os mortais - conquistavam a imortalidade através do reconhecimento e louvor de suas ações: adquiriam uma imortalidade mundana, ou seja, uma forma de permanecer no mundo mesmo depois da morte. Essa possibilidade, que advinha da ação, movia sua própria realização por atribuir sentido a ela: afinal, ao retirar-se deste mundo, seu agente permanecia vivo na memória da sua comunidade. A imortalidade era conquistada por um homem quando este tivesse sido capaz de deixar entre os seus algo grandioso que pudesse ser narrado depois de sua morte.

Com a novidade do cristianismo ${ }^{26}$ a imortalidade se estendeu a todos os homens, independentemente de suas ações para o mundo e para as gerações seguintes: a conquista da imortalidade era certa e as atitudes individuais (e muitas vezes ocultas) é que definiam seu rumo para o bem ou para o mal. Assim, a partir da crença na imortalidade da alma, a vida individual passa a assumir um valor de sacralidade até então desconhecido, pois, embora ela não tivesse mais um fim determinado, tinha um começo: esse começo, que é o nascimento, é a única condição necessária para a imortalidade da alma.

A consequência dessa ideia foi uma inversão na hierarquia presente entre vida e mundo da Antiguidade. O envolvimento com o mundo, antes condição da imortalidade, deixa de ser relevante e até mesmo desejável, pois a contemplação assume o lugar de atividade superior. A relação dos homens com o mundo perdeu sua importância e a vida individual foi promovida à categoria de bem maior. Assim, qualquer outra atividade mundana, inclusive a

26 Arendt distingue a vida de Jesus de Nazaré da assimilação posterior de suas ações e pregações por Paulo e pela Igreja. Um dos exemplos que podemos citar a esse respeito está relacionado à discussão que está sendo apresentada neste capítulo. Sobre a elevação da vida como bem supremo e a inversão de valoração entre as atividades humanas, Arendt (2005a, p. 331-332) afirma: "É verdade que dificilmente se encontraria tal convicção, certamente devida à influência da filosofia grega, nas pregações de Jesus de Nazaré; contudo, mesmo que a filosofia medieval houvesse sido mais fiel ao espírito dos Evangelhos, dificilmente teria encontrado neles algum motivo para glorificar o labor. A única atividade que Jesus de Nazareth recomenda em suas pregações é a ação". 
atividade política, passou a ser entendida como um ônus necessário consequente da natureza pecaminosa dos homens. Esse interesse extraterreno resultou obviamente em uma alienação do mundo e a vida passou a ocupar o lugar que antes era exercido pelo corpo político. Por mais que o cristianismo e muitos de seus dogmas tenham sido abalados, a vida se manteve entendida como o mais alto bem, e todo esse processo gerou o abandono dos temas do mundo e, especialmente, uma alienação em relação aos temas públicos.

A elevação da contemplação como atividade superior acentuou o desinteresse pelas questões mundanas, por se traduzir na atividade através da qual os homens se dedicam ao conhecimento da verdade mais pura, tendo como condição o afastamento do mundo. Embora a valorização da contemplação não tenha se mantido historicamente, o afastamento dos homens das questões do mundo permaneceu. O primeiro grande golpe sofrido pela contemplação, segundo Arendt (2005a), se deu com a descoberta de Galileu. Ao comprovar, por meio de um instrumento construído por suas mãos, que era a Terra que girava em torno do Sol (e que nossos sentidos estavam enganados a respeito do que acreditávamos ser o contrário), se estabeleceu entre nós a desconfiança a respeito de nossos próprios sentidos. Mais tarde, com a Reforma Protestante e a filosofia de Descartes, respectivamente, a fé tornou-se cada vez mais um tema individual, e a dúvida a única certeza. Por essas razões, tanto a contemplação quanto os dogmas cristãos sofreram um profundo abalo. Apesar desse fato, o valor da vida acima de todos os outros prevaleceu e tudo passou a se subordinar a ele.

Embora a descoberta de Galileu tenha provocado a valorização da atividade da fabricação (e não do labor), já que foi um produto construído por mãos humanas que provocou a grande reviravolta, o consumo transformou as condições da própria atividade do homo faber. Na medida em que gradativamente a vida assumiu o lugar de mais alto bem, o social ganhou espaço e fomos nos tornando uma sociedade de consumidores; o funcionamento da atividade do labor prevaleceu. Dessa forma, transformamos nossa relação com a atividade da fabricação e descaracterizamos suas condições. Consequentemente, o mundo já não oferece mais estabilidade para a nossa existência, não mais sustenta as nossas relações, e o elenco de experiências do passado não nos serve mais de guia para a forma de nos movermos no mundo. Nesse sentido, a ascensão do social e a coroação do animal laborans contribuíram para a situação de desertificação em meio a qual nos encontramos e a que Arendt se refere.

Concebendo todas as coisas como funções do processo vital, numa sociedade 
completamente 'socializada', como a sociedade de massas de operários, a distinção entre fabricação (work) e trabalho (labor) passa a não ter sentido sendo abandonada em favor do trabalho (labor). Dentro do sistema de referência do ponto de vista social 'todas as coisas tornam-se objeto de consumo'. O animal laborans, pela sua atividade, não sabe construir um mundo nem cuidar do mundo criado pelo homo faber. Os produtos do trabalho, do metabolismo do homem com a natureza, não demoram no mundo o tempo suficiente para se tornarem parte dele' e a atividade do trabalho (labor), atenta somente ao ritmo das necessidades biológicas, 'inconsciente do mundo a ponto deste não existir'. Uma sociedade de massas de operários 'consiste em exemplares da espécie humana isolados do mundo': 'O animal laborans não foge do mundo, mas dele é expelido na medida em que está aprisionado na privatividade do seu próprio corpo, adstrito à satisfação de necessidades das quais ninguém pode compartilhar e nem comunicar completamente' (CORREIA, 2001, p. 236).

Fica evidente que cada um desses aspectos da crise do mundo moderno é de grande profundidade e alcance. Muitas outras reflexões poderiam ser feitas ou outros caminhos poderiam ser utilizados para compreendê-la. A escolha, neste trabalho, foi a de apresentar prioritariamente uma reflexão sobre a ascensão do social, pois mais uma vez se trata de um pensamento que Arendt elabora a partir da distinção de conceitos que se relacionam, mas que se encontram confundidos no mundo: as questões relativas às esferas pública e privada. É de conhecimento geral dentre os que se dedicam ao pensamento político de Arendt que o tema do social é um dos pontos mais criticados no conjunto de sua obra, pois, de fato, ela desconsidera a dedicação da política a alguns temas que entendemos como sendo fundamentais e que estão mais relacionados à garantia das mínimas condições da vida biológica e privada. Porém, apesar dos limites que essa discussão sobre o social no pensamento de Arendt nos oferece, ela é, sem dúvida, uma das mais iluminadoras para a compreensão sobre a situação de nosso mundo e da política. Portanto, estamos de acordo com Adriano Correia (2001, p. 241-242) quando afirma que

A questão do social em Hannah Arendt é certamente uma das partes mais problemáticas e frágeis da sua teoria política, na medida em que ela então se vê em dificuldades na compreensão dos problemas sociais com relevância política, mas ao mesmo tempo uma das mais iluminadoras, na medida em que traz à tona alguns elementos básicos da composição das massas, da relação cada vez mais promíscua entre política e economia e da moderna perda do senso comum. 
Além das questões relativas à ascensão do social (e a sociedade de massas), a vitória do animal laborans e a elevação da vida como bem supremo, outros dois aspectos da situação geral do mundo moderno revelam a condição de desertificação em meio à qual nos encontramos. As crises da autoridade e da tradição, além de estarem profundamente relacionadas entre si, intensificam o panorama da perda do mundo, e a reflexão sobre elas permite que ampliemos a compreensão sobre o fato de a crise da educação ser um problema político.

Arendt (2005b), em Que é autoridade?, pretende responder à pergunta do título em questão buscando identificar em nosso mundo experiências que revelem o que a autoridade significa. Porém, verifica que, no mundo moderno, até mesmo a autoridade que regia as relações educativas (entre pais e filhos, por exemplo) sofreu um forte golpe e, portanto, nem mesmo essa experiência pode iluminar nossa reflexão a respeito de seu significado. Apesar de apontar para o fato de a crise da autoridade estar fortemente presente até mesmo nas áreas privadas da vida, Arendt se volta para a compreensão sobre a autoridade política. Graças à ausência de experiências comuns de autoridade em nossos tempos, ela busca observá-la no passado desde suas primeiras aparições: na tentativa de elaboração desse conceito na filosofia grega platônica e aristotélica e na experiência autêntica da autoridade política da Antiguidade Romana. Além de revelar a origem do fenômeno, Arendt denuncia também seu fim, situando o desaparecimento da autoridade no contexto do mundo moderno (antes mesmo do totalitarismo) com a perda do prestígio do sistema de partidos e a falta de reconhecimento da autoridade dos governos. Apesar de situar na primeira metade do século $\mathrm{XX}$ o desaparecimento da autoridade política, Arendt identifica muito antes o início de um processo gradativo e lento de sua derrocada (e sobre isso reflete detidamente).

Ainda no mesmo ensaio, Arendt revela que as crises da autoridade e da tradição estão profundamente unidas pelo fato de ambas, junto à religião, terem composto a tríade que fundamentava a Antiguidade Romana sustentando umas as outras. Essa tríade estava assentada no valor que os romanos atribuíam à fundação de Roma. A tradição, composta das histórias e princípios do povo romano, os mantinha unidos ao seu passado e a seus antecessores (e nesse contexto a religião de fato significava re-ligare). Consequentemente, a autoridade das figuras políticas se assentava no fato de terem recebido a transmissão dessa tradição e por ela terem se tornado responsáveis (uma autoridade derivativa do passado daquele mundo e de seus mortos). Para Arendt, foi com os romanos que a autoridade surgiu enquanto experiência política original, embora a filosofia grega tenha também provocado 
forte impacto, ao longo de toda a história do mundo ocidental, no significado do conceito de autoridade, enquanto esta existiu.

A tradição na Antiguidade Romana estabelecia a identidade daquele povo a partir de um passado comum e guiava suas ações. Embora tivesse sido elaborada e realizada no passado, estava permanentemente presente, representando o vigor de um mundo que oferecia sentido à existência daquela comunidade política. A autoridade, portanto, era exercida pelos homens que permaneciam fortemente ligados a essa tradição e que, por isso, tinham legitimidade reconhecida perante seu povo para ocupar o lugar de quem o conduzia. Segundo Arendt, a tradição não é idêntica ao passado, mas é o que nos une a ele. A autoridade é, então, o reconhecimento do valor dessa tradição e de tudo que faz referência a esse passado, o revela e atualiza: "a autoridade, assentando-se sobre um alicerce no passado como sua inabalada pedra angular, deu ao mundo a permanência e a durabilidade que os seres humanos necessitam precisamente por serem mortais [...]" (ARENDT, 2005b, p. 131). Tradição e autoridade, portanto, estavam fortemente relacionadas e sustentavam uma a outra pelo fato de ambas encontrarem sua razão de ser na permanência do mundo que estabelecia a identidade do povo romano.

A partir dessa reflexão realizada por Arendt sobre a Antiguidade Romana, podemos compreender uma afirmação de A Crise na Educação que estabelece relação direta entre a educação e a política.

Contra o pano de fundo inabalado de uma tradição dessa natureza, na qual a educação possui uma função política (e esse caso era único), é de fato relativamente fácil fazer direito as coisas em matéria de educação, sem sequer fazer uma pausa para apreciar o que se está fazendo, tão completo é o acordo entre o ethos específico do princípio pedagógico e as convicções éticas e morais básicas da sociedade como um todo (ARENDT, 2005b, p. 244, grifo nosso).

Vimos que os romanos constituíam uma comunidade política assentada numa fundação capaz de atribuir sentido a essa comunidade e que, portanto, estabeleceram entre si formas de preservação desse mundo. Uma das formas que encontraram foi a própria autoridade política reconhecida no senado. Outra maneira de realizarem essa preservação, além da política, era educando os jovens romanos em sua tradição. Se o sentido da própria tradição era o de manter os homens do presente ligados ao passado, essa herança tinha que ser 
comunicada a todas as gerações. Educar era, então, uma das maneiras de oferecer estabilidade ao mundo compartilhado por aqueles homens, preservando o que foi fundado.

Arendt, portanto, reconhece que entre os romanos a educação exerceu de fato uma função política. Apenas sob a luz de suas considerações a respeito da tradição e da autoridade nesse contexto, entendidas como fenômenos fundamentais à estruturação desse mundo em questão, aquela afirmação em relação à função política da educação, encontrada em A Crise na Educação, pode ser compreendida. $\mathrm{O}$ argumento de Arendt para admitir tal função para a educação na Roma Antiga está relacionado à significação que aquele mundo oferecia ao povo: algo que era permanentemente atualizado pelos homens que dele faziam parte. A política e a educação desempenhavam, juntas, a conservação do que compartilhavam e lhes oferecia sentido.

\footnotetext{
No âmago da política romana, desde o início da República até virtualmente o fim da era imperial, encontra-se a convicção do caráter sagrado da fundação, no sentido de que uma vez alguma coisa tenha sido fundada, ela permanece obrigatória para todas as gerações futuras. Participar da política significava, antes de mais nada, preservar a fundação da cidade de Roma (ARENDT, 2005b, p. 162).
}

Preservar a fundação da cidade de Roma nada mais é do que preservar o mundo existente e instituído naquele momento; e a política romana estava, evidentemente, voltada a essa preservação. No entanto, não seria também essa a responsabilidade que Arendt atribui à educação em termos gerais (algo que discutimos no capítulo anterior)? Retomaremos isso mais adiante, mas antes concluiremos nossa reflexão sobre o significado do desaparecimento da autoridade como fenômeno político e sobre a crise da tradição no contexto do mundo moderno.

Historicamente, o fato é que a tríade religião, tradição e autoridade amalgamou-se ainda mais fortemente com o cristianismo e, mais propriamente, com a conformação da Igreja enquanto instituição. Nesse momento, muitas das concepções da filosofia platônica transformaram, em alguns aspectos, o conceito de autoridade até então experienciado pelos romanos. Com isso, a tradição, que, até o momento estava assentada no mundo humano, passou a ser considerada de ordem divina e atemporal. Muito mais tarde, com o desafio de Lutero à autoridade da Igreja, um dos pilares da tríade sofreu um forte abalo, iniciando a ruína também da força unificadora da religião e da tradição.

Não são as razões históricas dessa crise que nos interessam aqui, mas sim a situação 
do mundo em que vivemos a partir do fim da tradição e do desaparecimento da autoridade. Sobre a autoridade, Arendt (2005b, p.132) afirma

\begin{abstract}
Sua perda é equivalente à perda do fundamento do mundo, que, com efeito, começou desde então a mudar, a se modificar e transformar com rapidez sempre crescente de uma forma para outra, como se estivéssemos vivendo e lutando com um universo proteico, onde todas as coisas, a qualquer momento, podem se tornar praticamente qualquer outra coisa.
\end{abstract}

Essa condição de um mundo que não tem fundamentos e que se transforma tão rapidamente nos remete mais uma vez à situação do deserto a que Arendt se refere. Portanto, essa é mais uma manifestação da crise do mundo moderno que acentua a perda do mundo apresentada anteriormente, mas aqui revelada em mais uma de suas facetas. A crise da autoridade se revela como sendo mais um elemento gerador de instabilidade e, portanto, mais um motivo da ausência de referenciais seguros de mundo. Com a perda da experiência da autoridade, a tradição também entrou em crise, intensificando ainda mais essa situação afinal, com tal crise, perdemos o fio capaz de nos unir ao sentido de nossa existência, nos deixando soltos num mundo fluido.

\footnotetext{
Com a perda da tradição, perdemos o fio que nos guiou com segurança através dos vastos domínios do passado; esse fio, porém, foi também a cadeia que aguilhou cada sucessiva geração a um aspecto predeterminado do passado. [...] Mas não se pode negar, sem uma tradição firmemente ancorada - e a perda dessa firmeza ocorreu muitos séculos atrás -, toda a dimensão do passado foi também posta em perigo. Estamos ameaçados de esquecimento, e um tal olvido - pondo inteiramente de parte os conteúdos que se poderiam perder - significaria que, humanamente falando, nos teríamos privado de uma dimensão, a dimensão de profundidade na existência humana (ARENDT, 2005b, p.130).
}

Evidentemente, uma crise relacionada à ligação que temos com o nosso passado afeta profundamente a educação, que, como vimos, se caracteriza, segundo Arendt, por ser uma atividade desempenhada com os olhos postos nele (o que nos permite identificar o que pretendemos perpetuar). Sem a clareza sobre o que manter de nosso mundo - dentre as heranças que recebemos dos homens que aqui estiveram, agiram, pensaram e julgaram -, a 
tarefa educativa sofre um forte abalo. O fato é que as considerações de Arendt sobre a crise da autoridade e da tradição apontam para importantes desdobramentos para a educação. Com a perda da tradição não encontramos entre nós um mundo vigoroso e significativo a ser preservado, e com a crise da autoridade (presente também nas relações educativas) o lugar de responsabilidade assumido pelos adultos diante do mundo não é mais reconhecido pelas crianças como sendo legítimo (até mesmo porque, frequentemente, nós mesmos não agimos de maneira a assumi-la).

Para além da possibilidade de identificarmos as crises da autoridade e da tradição relacionadas à crise na educação, as reflexões de Arendt sobre a Antiguidade Romana apontam também para o fato de que, se o mundo se apresenta bem fundamentado e forte, a educação assume uma função política, ampliando nossas considerações a respeito da relação entre os dois âmbitos que temos procurado compreender até então. Num contexto no qual existe a força de uma fundação, histórias de ações significativas, uma ordem clara e um passado que une e identifica, a tarefa de preservar este mundo pela educação assume uma dimensão política tanto quanto a ação.

\footnotetext{
Nas palavras de Políbio, educar era simplesmente 'fazer-vos ver que sois inteiramente dignos de vossos antepassados', e nesse mister o educador podia ser um 'companheiro de luta' ou um 'companheiro de trabalho' por ter também, embora em nível diverso, atravessado a vida como os olhos grudados no passado. Companheirismo e autoridade não eram nesse caso senão dois aspectos da mesma substância, e a autoridade do mestre arraigava-se firmemente na autoridade inclusiva do passado enquanto tal (ARENDT, 2005b, p.245).
}

Na Antiguidade Romana, tanto a autoridade presente na política quanto a autoridade presente na educação tinham um mesmo fundamento. Portanto, a função política da educação, num contexto como aquele, pode ser comparada à ação que atualiza uma tradição. Mas é importante que consideremos que, quando uma comunidade antes coesa estiver prestes a ruir (fim necessário do caminho imposto pelo automatismo), apenas uma nova ação fundadora pode salvá-la dessa condição iminente de desaparecimento, ou seja: nunca a educação, mas sim a política. Mais uma vez, a relação que existe entre a educação e a política se dá a partir de limites claros entre elas, sem identificá-las, mas relacionando-as profundamente, sempre preservando nas mãos dos adultos a responsabilidade pelo mundo.

A reflexão sobre essa relação nos revela que, num mundo em pedaços como o nosso, a 
função política da educação (que é a de preservar o mundo) está tão perdida quanto a própria política. Se antes havíamos reconhecido que a crise que afeta a educação é um problema político por ser decorrente de uma crise dessa ordem, agora temos mais uma confirmação: afinal, se num mundo coeso a educação assume uma função política, num mundo em pedaços ela sofre da ausência de sentido que apenas o mundo comum pode lhe oferecer. Portanto, somente um mundo compartilhado significativo sustenta o vigor da política e também da educação. Quando o mundo perde vigor, a educação se esvazia de sentido, já que não sabemos mais em nome de que educar.

\footnotetext{
O problema da educação no mundo moderno está no fato de, por sua natureza, não poder esta abrir mão nem da autoridade, nem da tradição, e ser obrigada, apesar disso, a caminhar em um mundo que não é estruturado nem pela autoridade nem tampouco mantido coeso pela tradição (ARENDT, 2005b, p.245).
}

Nossa breve reflexão (e insuficiente em termos gerais) sobre as manifestações da crise do mundo moderno aponta para a perda do mundo e revela o que na verdade é uma crise política. Ao comparar a condição de nosso mundo à situação de um deserto, Arendt (2008, p. 267) afirma e reconhece que "o que deu errado foi a política". A perda do mundo fez com que os homens deixassem de reconhecer nela a responsabilidade que se traduz no amor mundi de Arendt: a aspiração de que o mundo permaneça traduzida na responsabilidade por sua continuidade. Num mundo em crise (que no nosso caso se traduz numa ausência de mundo), a própria política se esvazia por não encontrar o que conservar, assim como a educação. Afinal, como preservar algo que aparentemente não temos mais? Se a educação está relacionada à responsabilidade pela preservação do mundo (como vimos no capítulo anterior), ela tem em si uma dimensão política, afinal tal responsabilidade é dessa natureza.

Apesar de Arendt manifestar em seu pensamento forte admiração por experiências políticas do passado, como por exemplo as da Antiguidade Grega e Romana, ela não pretende que restabeleçamos tais realidades, mas se refere a elas para que possam iluminar nossas reflexões. No passado Arendt busca elementos que podem ter permanecido obscurecidos e que, depois de descobertos e significados por ela por meio do pensamento, sejam capazes de nos conduzir à compreensão das condições humanas no mundo moderno. Diante da crise, Arendt confia na possibilidade de que sejamos capazes de encontrar novas respostas políticas por meio da ação e do discurso e, por essa razão, ela não nos oferece propostas de condução 
dos assuntos de nosso mundo. Para ela isso é algo a ser realizado pelos homens plurais e não pela mera elaboração mental de um só, afinal "[...] respostas são dadas [...] no âmbito da política prática, sujeitas ao acordo de muitos; jamais poderiam se basear em considerações teóricas ou na opinião de uma pessoa só, como se se tratasse de problemas para os quais só existe uma solução possível" (ARENDT, 2005a, p. 13). Encontramos em sua obra muitos momentos que revelam que Arendt não pretende restabelecer qualquer realidade política ou mundana, mas que, para ela, a própria crise se traduz numa oportunidade para respostas novas. Ao considerar as perdas da tradição e da autoridade, respectivamente, Arendt (2005b, p.130-132) afirma:

Poderia ocorrer que somente agora o passado se abrisse a nós com inesperada novidade e nos dissesse coisas que ninguém teve ainda ouvidos para ouvir [...] a perda da permanência e da segurança do mundo [...] não acarreta, pelo menos não necessariamente, a perda da capacidade humana de construir, preservar e cuidar de um mundo que nos pode sobreviver e permanecer um lugar adequado à vida para os que vêm após.

Portanto, apesar de a crise nos deixar sem referências, não nos torna necessariamente incapazes de pensar, julgar, agir e nem mesmo educar. $\mathrm{O}$ que de fato acontece é que a crise, apesar da falta de estabilidade que gera entre nós (e justamente por ela), propicia uma situação de abertura para o pensar e para novos exercícios de julgamento sobre o mundo, porque as respostas ou soluções, até então aceitas, já não se mostram em condições de nos guiar. Embora a palavra crise nos remeta à ideia de perda e facilmente nos conduza a uma sensação de negatividade diante de determinada situação, Arendt vê na abertura provocada pela ausência de respostas pré-estabelecidas uma possibilidade: a da reflexão e do julgamento, que buscam novos parâmetros além da permanente possibilidade que existe entre os homens de criarem e estabelecerem algo comum inesperado e significativo.

Uma crise nos obriga a voltar às questões mesmas e exige respostas novas ou velhas, mas de qualquer modo julgamentos diretos. Uma crise só se torna um desastre quando respondemos a ela com juízos pré-formados, isto é, com preconceitos. Uma atitude dessas não apenas aguça a crise como nos priva da experiência da realidade e da oportunidade por ela proporcionada à reflexão (ARENDT, 2005b, p. 223). 
Talvez possamos encontrar no passado algo que ele ainda não nos disse. Talvez um grupo de homens funde algo absolutamente novo a partir de sua ação. $\mathrm{O}$ fato é que o mundo moderno ainda não encontrou nada no passado que possa oferecer novo sentido ao mundo, e muito menos fomos capazes de instituir entre nós algo que ao mesmo tempo seja surpreendente por ser novo, mas que também se torne seguro e duradouro. Por isso não só a política permanece em crise, mas também a educação.

A educação está relacionada às condições do mundo tanto quanto a política. Sempre que os fundamentos de uma comunidade de homens são questionados, a educação é afetada diretamente. Se pela educação assumimos a responsabilidade de preservar o mundo comunicando-o aos novos, sua preocupação está em manter entre nós o que nos une. Porém, no mundo moderno, apesar de reunidos, nos mantemos isolados: nos falta essa dimensão compartilhada da existência. A perda do mundo faz com que a educação perca suas referências e por isso ela é tão especialmente afetada. Se a educação existe para oferecer aos novos o que de comum foi estabelecido pelos homens anteriores a eles, mas não temos mais a evidências dessa condição, ela se esvazia, em grande parte, da tarefa que sua essência impõe.

\subsection{A crise na educação e a abertura para discussões políticas}

Embora não recaia sobre a educação a responsabilidade de encontrar respostas e soluções para o nosso mundo, ela se vê em meio a dificuldades internas que expressam a crise do mundo moderno, com as quais tem de lidar e para as quais tem de buscar saídas. Algumas dessas dificuldades ela mesma não é capaz de resolver internamente, ou seja, junto às crianças pelas quais responde. Isso torna a situação da educação um problema político, não apenas por estar relacionada às manifestações da crise do mundo moderno (a ascensão do social, a elevação da vida como bem supremo, a sociedade de consumidores, etc.), mas também por exigir reflexão, julgamento e decisões constantes sobre que mundo preservar, já que não há definições e evidências a esse respeito (situação que qualquer crise do mundo por si mesma impõe para todos os âmbitos fortemente relacionados a ele e à existência dos homens que o compartilham). Assim, a discussão constante entre adultos plurais sobre a educação é parte da condição em que ela se encontra, afinal, "sempre que a relevância do discurso entra em jogo, a questão torna-se política por definição, pois é o discurso que faz do 
homem um ser político" (ARENDT, 2005a, p. 11).

$\mathrm{O}$ fato de Arendt discutir a educação em meio ao conjunto de sua obra também aponta para o caráter político das questões que a envolvem. Se a educação fosse um âmbito que envolvesse meramente questões de ordem técnica, ela dispensaria discussão, reflexão e julgamento político. Em A Crise na Educação, Arendt (2005b, p. 222) apresenta razões para considerar "aconselhável ao leigo dar atenção a distúrbios em áreas acerca das quais, em sentido especializado, ele pode nada saber (...)" e também se reconhece nessa situação quando afirma a seu próprio respeito: “(...) esse é, evidentemente o meu caso ao tratar de uma crise na educação, posto que não sou educadora profissional (...)". As razões expressas que fazem Arendt entender a crise na educação como sendo um problema que envolve discussão política são, como vimos, o fato de ela ser decorrente da crise do mundo moderno e, também, a identificação da própria crise como uma situação de abertura que favorece a discussão e julgamentos políticos.

Evidentemente, não podemos deixar de considerar o fato de a educação ser um tema que envolve as relações dos homens com o mundo e suas relações entre si. Portanto, as respostas às questões educacionais que envolvem o sentido de pertencimento ao mundo e responsabilidade por ele não são resultado de investigações empíricas ou de mera resolução estratégica, como tampouco ficam circunscritas àqueles que se dedicam profissionalmente a ela, mas advêm do exercício da reflexão e do confronto de diferentes discursos a seu respeito. Muitas são as definições na educação a respeito do conteúdo e forma de agir diante das pessoas e do mundo que passam por escolhas políticas, seja em âmbito nacional ou institucional. Porém, a reflexão de Arendt alerta para o fato de que mesmo as considerações a respeito da educação - e especialmente a elaboração dos discursos educativos - padecem da mesma dificuldade que a própria política encontra em nossos tempos: conseguir desprender-se do automatismo imposto pela ruína que a crise nos revela, encontrando, apesar dele, um sentido comum fundado num passado e numa tradição que não é mais reconhecida como tal.

Assim, os aspectos da crise do mundo moderno estão tão fortemente impregnados no pensamento, discursos e práticas relacionadas tanto à política quanto à educação, que muitas vezes as respostas encontradas não são nada mais do que outras manifestações da própria crise. Isso fica evidente quando Arendt (2005b, p. 230-232) aponta para o que considera serem os três pressupostos básicos da crise na educação, a saber: que existe um "mundo de crianças e uma sociedade formada por elas"; que a Pedagogia é "uma ciência do ensino em geral a ponto de se emancipar inteiramente da matéria efetiva a ser ensinada"; e "que só é 
possível conhecer e compreender aquilo que nós mesmos fizemos”.

Embora cada um desses pressupostos tenha sido elaborado como resposta à situação de crise instalada na própria educação, neles estão contidos os sintomas da perda do mundo comum. No primeiro deles, com a ausência de um mundo comum capaz de guiar o adulto em sua tarefa educativa, acabamos por criar a ideia de um mundo de crianças como se elas fossem capazes de estabelecer sozinhas algo compartilhado com condições de guiá-las entre si (ou ainda como se tivessem a capacidade de responder, sem a ajuda do adulto, por algo comum e pelas relações que surgem daí). O segundo pressuposto revela a indefinição a respeito de que herança os homens devem preservar, propondo como solução o abandono da matéria do ensino (composta das histórias e produções humanas) para pretender um foco nas técnicas e estratégias de aprendizagem (como se elas pudessem existir independentemente de qualquer conteúdo). No terceiro pressuposto, fortemente relacionado ao anterior, está contida a perda das experiências comuns, já que em grande medida considera-se que o que se aprende é fruto de uma atividade próxima da fabricação, retirando o sentido humanista da educação e desconsiderando que muito do que é aprendido se realiza pela narrativa da experiência de outros homens no passado (e não dos próprios alunos no presente).

Apesar de termos mencionado brevemente essas relações entre os três pressupostos da educação no mundo moderno e a própria crise a que ela está sujeita, estão presentes muitas outras relações sobre as quais a própria autora se dedica a refletir. Mas o que existe de mais fundamental nessa revelação é a dificuldade que encontramos em tratar das questões relativas ao mundo dos homens sem nos deixarmos levar pela força da crise que nos arrasta para a ruína. Portanto, somente a consciência e reflexão sobre a situação de nosso mundo nos permitem essa percepção ou alguma criticidade sobre o que se passa no interior das questões que envolvem a educação na atualidade.

Para além das relações existentes entre a crise do mundo moderno e a situação da educação que fazem com que possamos afirmar que esta é um problema político, vale a pena retomarmos as considerações a respeito da dimensão política que nela está presente. Encontramos sempre associadas às afirmações de Arendt que estabelecem a separação entre os dois âmbitos considerações sobre a diferença entre as relações educativas e as relações políticas. Em tais afirmações, Arendt (2005a) retoma a ideia de uma igualdade fundamental entre os homens no desempenho da atividade política, sempre apresentada em contraposição à desigualdade evidentemente existente entre adultos e crianças nas relações educativas. Em meio a essas considerações encontramos também afirmações que claramente atribuem 
qualquer responsabilidade pelo mundo aos adultos, e não às crianças (seja ela a responsabilidade política ou educativa).

O papel desempenhado pela educação em todas as utopias políticas, a partir dos tempos antigos, mostra o quanto parece natural iniciar um novo mundo com aqueles que são por nascimento e por natureza novos. No que toca à política, isso implica obviamente um grave equívoco: ao invés de juntar-se aos seus iguais, assumindo o esforço de persuasão e correndo o risco do fracasso, há a intervenção ditatorial [...]. A educação não pode desempenhar papel nenhum na política, pois na política lidamos com aqueles que já estão educados. Quem quer que queira educar adultos na realidade pretende agir como guardião e impedi-los de atividade política. Como não se pode educar adultos a palavra 'educação' soa mal em política; o que há é um simulacro de educação, enquanto o objetivo real é a coerção sem o uso da força. Quem desejar seriamente criar uma nova ordem política mediante a educação, isto é, nem através de força e coação, nem através da persuasão, se verá obrigado à pavorosa conclusão platônica: o banimento de todas as pessoas mais velhas do Estado a ser fundado (ARENDT, 2005b, p. 225, grifo nosso).

[...] não apenas professores e educadores, porém todos nós, na medida em que vivemos em um mundo junto a nossas crianças e aos jovens, devemos ter em relação a eles uma atitude radicalmente diversa da que guardamos um para com o outro. Cumpre divorciarmos decisivamente o âmbito da educação dos demais, e acima de tudo do âmbito da vida pública e política, para aplicar exclusivamente a ele um conceito de autoridade e uma atitude face ao passado que lhe são apropriados mas não possuem validade geral, não devendo reclamar uma aplicação generalizada no mundo dos adultos (ARENDT, 2005b, p. 246, grifo nosso).

Arendt reconhece a igualdade como sendo uma condição para as relações políticas, e que a persuasão só pode se dar entre os homens se aquela for partilhada por eles. Embora sejamos plurais, e este seja o fundamento da política (pois só por essa razão esta pôde ser criada), a igualdade deve estar estabelecida entre aqueles que participam da política, afinal somente dessa forma podem se dispor a estabelecer juntos algo em comum. $\mathrm{O}$ estabelecimento dessa igualdade é, portanto, no pensamento de Arendt, uma conquista e um reconhecimento político. Por essa razão, ela encontra nas relações políticas fundamentadas pela autoridade uma contradição, afinal nelas está contida a ideia de que alguns se encontram 
em posição diferenciada, existindo uma hierarquia entre os homens no que diz respeito ao direito e à responsabilidade política.

[...] há tempos imemoriais nos acostumamos, em nossa tradição de pensamento político, a considerar a autoridade dos pais sobre os filhos e de professores sobre alunos como o modelo por cujo intermédio se compreendia a autoridade política. É justamente tal modelo, que pode ser encontrado já em Platão e Aristóteles, que confere tão extraordinária ambiguidade ao conceito de autoridade em política. Ele se baseia sobretudo em uma superioridade absoluta que jamais poderia existir entre adultos e que, do ponto de vista da dignidade humana, não deve nunca existir. Em segundo lugar, ao seguir o modelo da criação dos filhos, baseia-se em uma superioridade puramente temporária, tornando-se, pois, autocontraditório quando aplicado a relações que por natureza não são temporárias - como as relações entre governantes e governados (ARENDT, 2005b, p. 241).

A autoridade dos adultos sobre as crianças revela uma situação absolutamente diferente da expressa na autoridade política por estar, para Arendt, primeiramente fundamentada numa ordem natural. Os adultos, ao trazerem as crianças à vida, responsabilizam-se por elas, pois estas dependem absolutamente do provimento das necessidades que só aqueles podem realizar em seu lugar. Tal responsabilidade é análoga ao cuidado que desempenham os exemplares adultos de outras espécies animais por seus filhotes, sendo, portanto, fundamentada numa necessidade natural. No caso dos homens, esse cuidado assume caráter de responsabilidade que se expressa na autoridade, pois, como vimos, não nascemos apenas para a vida, mas também para o mundo.

Essa autoridade só existe porque há outra diferença fundamental entre adultos e crianças, que a educação é responsável por minimizar até sua eliminação: o pertencimento ao mundo. Para tornarem-se igualmente responsáveis pelo mundo os jovens precisam se tornar adultos. Essa condição não é apenas conquistada pela educação, mas também está culturalmente relacionada a ela.

[...] a linha traçada entre crianças e adultos deveria significar que não se pode nem educar adultos nem tratar crianças como se elas fossem maduras [...]. É impossível determinar mediante uma regra geral onde a linha limítrofe entre a infância e a condição adulta recai, em cada caso. Ela muda frequentemente, com respeito à idade, de país para país, de uma civilização para outra e também de indivíduo para 
indivíduo. A educação, contudo, ao contrário da aprendizagem, precisa ter um final previsível. Em nossa civilização esse final coincide provavelmente com o diploma colegial [...] (ARENDT, 2005b, p. 246).

Embora não seja claro o final da infância de uma criança e o início de sua existência como jovem adulto, quando uma determinada comunidade política define um término para o processo educativo básico, espera-se que com ele esses jovens tenham conquistado suficiente conhecimento de mundo para a existência entre outros homens em meio a este mundo. Espera-se que esses jovens reconheçam que, de fato, receberam uma herança e que, a partir dela, percebam sua condição de participantes de uma linhagem, de um grupo de homens que elaborou algo no passado e o entregou em suas mãos (por mais acidental que tenha sido o curso do mundo, apesar das diferentes tentativas de autoria dessa história). É a condição de pertencimento - que se pretende que seja conquistada pela educação - que nos confere responsabilidade pelo mundo.

Assim, embora a própria educação contribua para o estabelecimento da igualdade política por buscar o pertencimento dos recém-chegados ao mundo, é a condição de desigualdade que marca suas relações enquanto realizada pelos adultos na relação com os novos. Essa desigualdade decorre fundamentalmente do pertencimento ao mundo e da responsabilidade por ele que têm apenas os adultos. Apenas a constatação de que as relações educativas são marcadas pela desigualdade entre adultos e crianças já bastaria para que Arendt realizasse as afirmações de separação radical entre a educação e a política. Além disso, Arendt reconhece que as relações educativas dependem da autoridade, diferentemente das relações políticas, já que ela mesma encontra uma contradição inerente à autoridade política (mesmo reconhecendo sua relevância enquanto experiência condutora das relações políticas por um longo período de tempo, enquanto os homens, em comum acordo, reconheciam nela alguma legitimidade).

Mas será que o fato de afirmarmos que a educação não se realiza por relações igualitárias entre adultos e crianças retira dela toda e qualquer dimensão política? Para respondermos a essa questão basta compreendermos que a educação, entendida de maneira ampla, não se resume à relação dos adultos com as crianças, mas vai muito mais além, especialmente em tempos de crise do mundo (e, para nos referirmos a esse fato, refletiremos agora mais detidamente sobre a situação da educação escolar). O que podemos dizer das definições a respeito da educação realizadas pelo Estado, por exemplo? E sobre as relações 
institucionais (presentes na escola) entre os adultos que discutem e decidem a seu respeito?

Embora se realize pela relação entre adultos e crianças, o ato educativo depende de definições e escolhas anteriores ao momento em que eles estão juntos (fato sobre o qual Arendt não se dedica a refletir em A Crise na Educação). As relações entre adultos, que são parte do âmbito da educação e antecedem a relação com as crianças, frequentemente são relações políticas que envolvem decisões dessa ordem. Afirmar isso não significa supor que todas as relações entre adultos sejam políticas, como não o são, por exemplo, a amizade, o amor, as relações familiares, as relações entre empregados e dirigentes de uma empresa privada, ou até mesmo aquelas que envolvem questões estratégicas relativas ao ensino. Mas, sem dúvida, as discussões sobre a educação relativas ao quê perpetuar de nossa comunidade para as novas gerações - sejam conteúdos ou princípios - envolvem reflexões e julgamentos a respeito da existência no mundo comum e são discussões políticas.

Educar supõe tomada de decisões a respeito do quê se pretende preservar e sobre como se deve agir na educação para com os novos e para com o mundo. Tais decisões estão diretamente relacionadas à cultura de uma determinada comunidade política e nenhum desses temas é exato ou supõe verdades inquestionáveis. Do ministério à sala dos professores, adultos refletem, julgam e decidem a respeito da educação. Grande parte dessas deliberações são claramente políticas, pois dizem respeito ao mundo, além de envolverem discussões de natureza persuasiva. Embora muitos pedagogos e especialistas de forma geral insistam em retirar da educação essa dimensão política, afirmando que ela apenas deve ser aprimorada tecnicamente, isso não é possível. Não se pode reduzir a educação ao ensino entendido meramente como uma técnica, desconsiderando que nele haja um caráter educativo e um sentido formativo, de pertencimento ao mundo dos homens. Embora seja parte essencial da educação escolar as reflexões de natureza pedagógica ou, ainda, de natureza privada (como, por exemplo, quando a escola pensa a realidade de vida de determinada criança em seu lar, ao notar que condições mínimas de assistência não estão sendo oferecidas), as reflexões de natureza políticas também a constituem. A dimensão humana e mundana da educação é absolutamente histórica, como qualquer outra questão dessa natureza e está constantemente sob a deliberação dos homens em conjunto (especialmente no caso de um mundo como o nosso, que não nos fornece seguranças e respostas satisfatórias).

Referimo-nos acima à educação escolar, pois a familiar, apesar de também realizar a apresentação do mundo, não envolve discussões de caráter público (embora cada vez mais as questões relativas à educação desse âmbito estejam sendo expostas para julgamento coletivo, 
fenômeno relacionado à ascensão do social). A educação escolar é uma convocação do mundo público e está mais fortemente relacionada à formação da singularidade de cada homem, condição que, conjunta, fundamenta a política.

\begin{abstract}
Normalmente a criança é introduzida ao mundo pela primeira vez através da escola. No entanto, a escola não é de modo algum o mundo e não deve fingir sê-lo; ela é, em vez disso, a instituição que interpomos entre o domínio privado do lar e o mundo com o fito de fazer com que seja possível a transição, de alguma forma, da família para o mundo. Aqui, o comparecimento não é exigido pela família, e sim pelo Estado, isto é, o mundo público, e assim, em relação à criança, a escola representa em certo sentido o mundo, embora não seja ainda o mundo de fato. Nessa etapa da educação, sem dúvida, os adultos assumem mais uma vez uma responsabilidade pela criança, só que, agora, essa não é tanto a responsabilidade pelo bem-estar vital de uma coisa em crescimento como por aquilo que geralmente denominamos de livre desenvolvimento de qualidades e talentos pessoais. Isto, do ponto de vista geral e essencial, é a singularidade que distingue cada ser humano de todos os demais, a qualidade em virtude da qual ele não é apenas um forasteiro no mundo, mas alguma coisa que jamais esteve aí antes (ARENDT, 2005b, p. 238).
\end{abstract}

O fato de, em nosso mundo, ser o Estado quem convoca as crianças para a escola em caráter obrigatório faz com que ela represente o âmbito público e político para os novos, diferentemente da educação familiar, que, embora também comunique o mundo, está mais intensamente comprometida que a escolar com o cuidado da vida da criança e localiza-se na esfera privada da vida.

A dimensão política da educação fica comprometida quando entra em vigor um governo tirânico, totalitário ou ainda tecnocrático. Como vimos, a separação entre a educação e a política deve permanecer para que se mantenha a abertura para a possibilidade da ação futura dos jovens, imprevisível e livre, quando estes terminarem seu processo de formação. Portanto, se a educação for direcionada para uma realidade pretendida e determinada (se esta for entendida a partir da lógica de funcionamento da atividade da fabricação), ela perde sua condição de assunto político. Quando apenas um homem decide sobre ela, ou ainda quando a burocracia absoluta e impessoal impera, a educação também tem sua dimensão política comprometida. A pluralidade, que é fundamento da política, e a liberdade, que é seu sentido, devem estar presentes nas discussões e definições sobre a educação para que sua dimensão política permaneça preservada. Quando Arendt afirma a separação entre os dois âmbitos, ela 
evidentemente quer evitar o envolvimento das crianças em questões que ainda não lhes dizem respeito, além de pretender evitar também qualquer possibilidade de doutrinação e eliminação da possibilidade de pensar e, futuramente, de agir.

Preservada a separação da educação com uma 'política' de discurso unificado (com ressalvas ao uso do termo, pois para Arendt isso não pode ser entendido como sendo política), suas decisões envolvem uma pluralidade de homens. Além disso, a própria pluralidade é tema de discussão educacional e sua preservação no mundo pela própria educação contribui para a política futura. Quando reconhecemos na educação sua dimensão política, ela passa a ser entendida como um tema de ampla discussão e não apenas circunscrita a especialistas. A educação é um assunto político na medida em que é uma responsabilidade estendida (direta ou indiretamente) a todos os adultos diante do fato da natalidade.

Se nosso mundo se mostrasse vigoroso, a educação se realizaria com muito mais segurança e possivelmente não seriam tão urgentes e frequentes tantas discussões e definições a seu respeito. Mas em tempos de crise do mundo e do senso comum ${ }^{27}$ ela se torna âmbito de permanente reflexão, diálogo e tomada de decisões (a não ser que pretendamos reduzi-la às suas questões técnicas ou às questões do indivíduo psicologizado). Enquanto houver consciência da relevância da tarefa educativa para o mundo - embora em meio a um deserto -, seremos capazes de manter nossos esforços para que ela se realize. Para Arendt (2008, p. 267) “[...] só quem é capaz de padecer a paixão de viver sob as condições do deserto pode reunir em si mesmo a coragem que está na base da ação, a coragem de se tornar um ser ativo". Embora esse trecho faça referência à política, por se referir à ação, também educar - tarefa tão relacionada ao amor mundi quanto a política - exige de nós essa mesma condição de padecimento da paixão de viver num mundo que não mais nos inspira, mas no qual acreditamos que essa possibilidade de inspiração permaneça.

\footnotetext{
27 Arendt se apropria de algumas considerações de Kant sobre o julgamento estético em sua Crítica do juízo e apresenta sua leitura a respeito do que vem a ser o senso comum: "[...] sentido que nos ajusta a uma comunidade formada com os outros, que nos torna seus membros e capacita-nos a comunicar as coisas dadas pelos nossos cinco sentidos" (ARENDT, 2004, p. 205).
} 


\section{CONSIDERAÇÕES FINAIS}

Vimos que, de maneira incomum, Hannah Arendt estabelece uma separação radical entre a educação e a política (tanto em Reflexões sobre Litlle Rock quanto em A Crise na Educação). Especialmente entre aqueles que se dedicam a estudar os discursos e pensamentos sobre a educação, afirmações como essa geram forte estranhamento, afinal ela é comumente entendida como uma atividade de grandes implicações políticas (o que acontece também nos discursos correntes e não especializados).

Se encontrar afirmações de separação radical entre a educação e a política já é excessivamente incomum, encontrá-las em meio a um pensamento político e a uma análise política da situação de crise da educação gera ainda mais entranhamento. Tais afirmações de Arendt são tão veementes que muitas vezes levam os leitores menos familiarizados com sua obra a concluir que, para ela, não podem existir relações possíveis entre a educação e a política; ou, ainda, que essas afirmações não fazem qualquer sentido, ideia justificada pela falta de elementos evidentes para sustentá-las.

A ausência de tratamento direto ao tema mantém uma abertura para a reflexão e torna a questão particularmente inquietante. Além das afirmações de separação radical entre esses âmbitos terem se mostrado nebulosas e seus contextos não serem suficientemente esclarecedores, revelamos que outros elementos em meio a seus escritos apontam outras relações. São eles: o uso da expressão pré-política no pensamento de Arendt para designar a educação; o fato de a natalidade ser entendida como essência da educação; a responsabilidade que, tanto a educação quanto a política, assumem pelo mundo; e o fato de a crise na educação ser um problema político.

Mesmo sendo uma pensadora da política, Arendt faz considerações bastante interessantes do ponto de vista educacional e tece críticas a respeito de princípios que vêm sendo assimilados pelos discursos da área de maneira irrefletida. No entanto, é curioso que justamente a respeito da relação entre a educação e aquilo que vem a ser o centro de seu pensamento, a política, suas considerações tenham se mantido obscuras.

Antes de pensarmos essa relação, foi preciso que percorressemos o conjunto das obras de Arendt em busca da compreensão a respeito da própria política, algo que permeia todo o seu pensamento e vai sendo delineado em suas reflexões sobre as experiências mais marcantes do século XX, as quais são realizadas à luz de outros eventos do passado. Sem compreender o 
que é a política em seu pensamento - e também o que ela não é -, qualquer reflexão sobre o que Arendt pensa sobre a educação se torna limitada. O que ela entende por política muitas vezes surge a partir da negação do que esta parece ser mas não é. Se a política e seus conceitos constituintes não podem ser compreendidos profundamente sem serem pensados a partir de suas distinções, o mesmo se passa com a educação: se não refletirmos sobre ela a partir da política, da qual se distingue, sua compreensão fica comprometida.

Nossas reflexões a respeito do que Arendt aponta ser pré-político - ou seja, aquilo que se distingue da política, mas é anterior e necessário a ela - não só reafirmam a separação estabelecida entre os âmbitos em questão, mas também revelam outras relações fundamentais entre a educação e a política. Após considerarmos essas outras relações, vale perguntarmos: qual é a diferença fundamental entre o pensamento de Arendt e os outros discursos no que diz respeito à relação existente entre a educação e a política? Se apesar da separação estabelecida entre esses âmbitos verificamos outras relações que chegam até mesmo a revelar uma dependência, ou que nos conduzem ao reconhecimento de que elas compartilham a mesma responsabilidade (embora a desempenhem de maneiras distintas), em que exatamente está a contribuição de Arendt a respeito dessa relação?

A nosso ver, o grande diferencial deriva justamente da distinção e está relacionado à responsabilidade política. A determinação da distinção entre a educação e a política faz afirmar a responsabilidade dos adultos pelo mundo e permite que as crianças permaneçam preservadas desse envolvimento (ideia evidentemente presente em Reflexões sobre Little Rock quando Arendt condena a tentativa de integração entre brancos e negros nos Estados Unidos por meio das escolas).

Espera-se, com frequência, que a educação seja capaz de oferecer novas condições para uma determinada comunidade política, ou, muitas vezes, que ela seja a principal responsável pela manutenção de seus insucessos. Esses discursos, ao condenar a situação política, condenam a educação e afirmam que ela segue consolidando seus fracassos. A responsabilidade, portanto, nesses discursos, está bastante delimitada e costuma recair sobre os profissionais da educação, assim como as expectativas são depositadas nas próximas gerações.

No entanto, como as gerações se seguem e os discursos se mantêm (e parece que a educação não corresponde a tais pretensões de alteração da realidade de mundo), a condenação de todos aqueles que são imediatamente responsáveis pela educação permanece. O que de fato acontece é uma identificação entre a responsabilidade política e a 
responsabilidade educativa, como se esta fosse sua única forma possível de efetivá-la, e não apenas uma delas. Consequentemente, se estamos em tempos de desresponsabilização política - afinal existimos em meio a uma crise que torna o mundo um deserto e, assim, perdemos aquilo que nos une -, tais discursos só fazem acentuar a situação.

É no reconhecimento de que o curso do mundo está nas mãos de todos os adultos no tempo presente que está a grande contribuição de Arendt ao afirmar a distinção entre a educação e a política. Embora evidentemente a educação possa contribuir para gerar a responsabilização pelo mundo nos jovens, a responsabilidade não deve ser entendida como algo a ser aguardado. Além disso, os discursos que confundem a educação e a política comumente deixam de reconhecer os limites do alcance da tarefa educativa e a imprevisibilidade que ela (e a ação) supõe.

Assim, ao realizar a distinção entre esses âmbitos, Arendt devolve ao próprio âmbito da política a responsabilidade pelo curso do mundo. Nela os homens são capazes de estabelecer novas realidades de mundo: são capazes de agir de modo a fundar algo novo. Sendo assim, embora tenhamos evidenciado relações até mesmo essenciais entre a educação e a política no pensamento de Arendt, a distinção se mantém e torna suas considerações políticas sobre a educação absolutamente diferentes daquelas que encontramos comumente em outros discursos. A reflexão sobre a relação entre elas no pensamento de Arendt, guiada pelo exercício da distinção, revela limites e relações que permaneciam obscurecidos e, assim, nos oferece condições para ressignificar tais fenômenos.

Concluímos, a partir da afirmação de Arendt a respeito da educação na Antiguidade Romana, que, num mundo vigoroso, ela se torna uma extensão da política. Essa extensão se mostra análoga à ação que atualiza essa realidade de mundo e, enquanto ele fizer sentido, contribui para a sua continuidade e segue em sua função política. Essa condição da educação se traduz no que neste contexto significava a expressão prattein, que era a capacidade de colocar algo em andamento (diferentemente do que era archein, traduzida na capacidade de começar algo, iniciar). A educação, nesse contexto, atualizava o que havia sido iniciado pela fundação, o sentido dessa comunidade política.

Sendo assim, se verificamos que a educação é um âmbito atualizador do mundo, será que, em tempos de crise, ela não está mais próxima de desempenhar a preservação do status quo (no sentido de preservação daquilo que existe e é indesejável), já que o mundo que ela hoje apresenta é de fato um mundo em ruínas? Muitos dos discursos sobre a educação a entendem dessa maneira e não nos parece absurdo considerar essa possibilidade. 
Mas mesmo se admitirmos que essa é uma condição da educação em tempos de crise, não poderíamos responsabilizá-la pela situação indesejável do mundo, afinal não recai sobre ela a capacidade de alterar o curso dessa realidade, pois ela representa apenas um âmbito de atualização do que está estabelecido. Quando o que temos no mundo não é mais reconhecido como algo suficientemente vigoroso, quando não existe mais o seu sentido comum, a educação - diante de seu limite enquanto âmbito transformador - acaba por continuar sua atualização. Mas nesse caso a atualização não é mais a de um mundo que faz sentido, mas de um mundo em ruína. Por essa razão a crise do mundo e da política, gera uma crise educacional.

Embora muitos possam crer que esse seja de fato o papel da educação, não consideramos que seja necessário que ela atue de maneira a reafirmar as realidades políticas. Entendemos que essa outra possibilidade de atuação da educação esteja relacionada ao que chamamos neste trabalho de sua dimensão política: as discussões e julgamentos políticos que se dão entre os adultos antes de essa atividade começar junto aos novos. A saída para que a educação não represente simplesmente a repetição da condição imposta pelo automatismo que conduz nosso mundo à ruína é considerar nossas perplexidades políticas sobre aquilo que não queremos para o nosso mundo e que expressam a própria crise. No entanto, a perplexidade tem como condição anterior o reconhecimento de que o mundo está em crise, mas que mesmo assim seguimos mantendo a esperança que deriva do amor que temos por ele. A dimensão política da educação só se esvazia se quem educa se isenta de perceber que o mundo está em pedaços e de se mobilizar por isso: ou seja, se isenta de amar o mundo.

Assim, essa outra forma de atuar na educação depende da compreensão do sentido da tarefa educativa em relação à sua responsabilidade pelo mundo, e da reflexão a respeito da situação em que ele se encontra. Ao escolher o que do mundo preservar, aqueles que educam podem negar o que no mundo reconhecemos como o caminho certo da ruína (por exemplo, o uso da violência nas relações entre iguais); podem escolher preservar elementos diferentes daqueles que se impõe pelo automatismo. A ruptura da tradição permite que se vasculhe heranças que estavam pouco aparentes, assim como Arendt faz com a própria política.

A atividade de educar, que expressa o mundo que temos (vigoroso ou não), não é necessariamente um instrumento de manutenção, como também não pode ser confundida com o âmbito capaz de mudar o curso do mundo. No entanto, embora reconheçamos os limites da tarefa educativa, não podemos anular seu alcance. A questão é que ele não pode nunca ser 
mensurado ou verificado de maneira certa. Quando alguém age politicamente, não há como saber qual foi a influência da educação sobre esse agente e sobre essa ação.

Se, do ponto de vista daquele que é educado, a educação antecede necessariamente sua participação política, do ponto de vista da educação, a política também a antecede de forma necessária. Isso porque a educação depende de um mundo vigoroso para caminhar repleta de sentido, algo que os homens só podem realizar na política. A mesma antecedência necessária se dá em tempos de crise, afinal a educação depende das discussões e julgamentos políticos a seu respeito.

Assim, a reflexão de Arendt, embora nunca prescritiva, pode nos oferecer algum sentido para a tarefa educativa: educar de forma a preservar a espontaneidade que há na infância, a gerar o reconhecimento da relevância das questões comuns, a dar ouvidos e vozes à pluralidade de culturas e pensamentos, a comunicar a beleza de algumas histórias humanas. Embora nossa intenção neste trabalho seja apenas a de realizar uma reflexão acerca da educação no pensamento de Arendt e sua relação com a política, ela é capaz de iluminar alguns princípios da atividade educativa (que vem acontecendo muitas vezes em plena escuridão e abandono).

Tais reflexões também nos conduzem à percepção de que nós mesmos somos responsáveis politicamente pelo mundo, liberando os jovens dessa tarefa enquanto estiverem na infância: esperando que a responsabilidade que assumimos diante do mundo (tanto na educação quanto na política) os inspire em suas ações futuras. O compromisso deve ser o de assumirmos o fato de nossa própria natalidade no tempo presente para mantemos abertura suficiente na prática educativa para que a ação futura possa se dar com os pés no mundo, seja ele qual for. Essa abertura não pode nunca representar um abandono, mas sempre a responsabilidade que enquanto adultos assumimos pelo mundo que temos. Assim, a esperança de Arendt está depositada na natalidade: nos homens que, em si, tem a possibilidade de confirmar a singularidade do seu nascimento através da ação, sua outra aparição para o mundo. É através da manifestação da natalidade na ação que se dá a política. E o mundo só pode ser preservado enquanto a possibilidade da ação permanecer viva em sua condição livre de fundar o novo.

Nesse sentido, "qualquer pessoa que se recuse a assumir a responsabilidade coletiva pelo mundo não deveria ter crianças e é preciso proibi-la de tomar parte em sua educação" (ARENDT, 2005b, p. 239). Educar e agir politicamente: ambas são responsabilidades pelo mundo. Mostra-se incompatível, para Arendt, assumir a responsabilidade pela educação se 
não houver em nós o reconhecimento de alguma responsabilidade política. Isso quer dizer que sem ser político não se deve ser educador. E tanto um como o outro dependem do amor que temos pelo mundo.

Por fim, concluímos nossas reflexões neste trabalho com uma afirmação de Arendt sobre fenômenos que ela entende serem pré-políticos: embora eles não sejam políticos, são "meios para proteger o espaço político, ou para fundá-lo e ampliá-lo - mas sem serem políticos em si como tal. São fenômenos marginais que pertencem ao fenômeno da coisa política e, por causa disso, não são ela" (ARENDT, 2007, p. 61). 


\section{REFERÊNCIAS}

ALMEIDA, V. S. Amor mundi e educação: reflexões sobre o pensamento de Hannah Arendt. Tese (Doutorado) - Faculdade de Educação, Universidade de São Paulo, São Paulo, 2009.

ARENDT, H. A Condição Humana. 10ª ed. Rio de Janeiro: Forense Universitária, 2005a.

A Dignidade da Política: ensaios e conferências. $3^{\text {a }}$ ed. Rio de Janeiro: RelumeDumará, 2002.

A promessa da política, Rio de Janeiro: Difel, 2008.

. Entre o passado e o futuro. 5 ed. São Paulo: Perspectiva, 2005b.

. Homens em Tempos Sombrios. São Paulo: Companhia das Letras, 1987.

. O que é política? 7 ed. Rio de Janeiro: Bertrand Brasil, 2007.

. Origens do totalitarismo. São Paulo: Companhia das Letras, 1989.

Responsabilidade e julgamento. São Paulo: Companhia das Letras, 2004.

. Sobre a violência. Rio de Janeiro: Ed. Civilização Brasileira, 2009.

Trabalho, obra, ação. Tradução de Adriano Correia. In: Cadernos de ética e filoso-

fia política, São Paulo, n. 7, 2/2005c, p. 175-201.

ARISTÓTELES. A política. São Paulo: Ícone Editora, 2007. 
BENJAMIM, W. Obras escolhidas: Magia e técnica, arte e política. 7 ed. v.1. São Paulo: Brasiliense, 1994.

BIGNOTTO, N. Uma sociedade sem virtudes? In: NOVAES, A. O esquecimento da política. São Paulo: Agir, 2007, p. 83-105.

BOBBIO, Norberto; VIROLI, Maurizio. República e Virtude. In: (orgs.) Diálogo em torno da República: os grandes temas da política e da cidadania. Rio de Janeiro: Ed. Campus, 2002.

CARVAlHO, J. S. F. (org). Educação, Cidadania e Direitos Humanos. Petrópolis, RJ: Vozes, 2004.

COMENIO, J. A. Didática Magna: tratado da arte de ensinar tudo a todos. 3 ed. Lisboa: Caloute Gulbenkian, 1985, p.181 - 303.

CONDORCET. Escritos Pedagógicos. Madrid: Talles Calpes. s/d., p. 5-219.

CORREIA, A.; NASCIMENTO, M. Hannah Arendt: entre o passado e o presente. Juiz de Fora: UFJF, 2008.

O desafio moderno: Hannah Arendt e a sociedade de consumo. In: MORAES, Eduardo J. de; BIGNOTTO, N. (orgs.). Hannah Arendt: diálogos, reflexões, memórias. Belo Horizonte: Ed. UFMG, 2001, p. 227-245.

DEWEY, John. Vida e Educação. São Paulo: Companhia Editoria Nacional, 1959, p.1-155.

DUARTE, André. Poder e violência no pensamento político de Hannah Arendt: uma reconsideração. In: Brasileira, 2009. p. 131-167. Sobre a Violência. Rio de Janeiro: Ed. Civilização

ERASMO. A civilidade pueril. Lisboa: Estampa, 1978, p.5-109. 
FOUCAULT, Michel. A verdade e as formas jurídicas. Rio de Janeiro: NAU Editora, 2002.

Os corpos dóceis. In:

.Vigiar e Punir. 27 ed. Petrópolis: Vozes. 2003, p.117-142.

O que são as luzes. In:

Arqueologia das ciências e história dos sistemas de pensamento. Rio de Janeiro: Forense, 2000, p. 335-351.

FREIRE, Paulo. Pedagogia da Autonomia: saberes necessários à prática educativa. 29 ed. São Paulo: Paz e Terra, 1996.

GRESPAN, Jorge. Revolução Francesa e Iluminismo. São Paulo: Contexto, 2003.

LEVINSIN, Natasha. The Paradox of Natality: Teaching in the Midst of Belatedness. In: GORDON, M. Hannah Arendt and education: renewing our common world. Boulder, CO: Westview Press, 2001, p 11-36.

HERBART, J. Pedagogia Geral. Lisboa: Fundação Calouste Gulbenkian, 2003, p.61-144.

JONES, P. A oração fúnebre de Péricles em 430. In: O mundo de Atenas: Uma introdução à cultura clássica ateniense. São Paulo: Martins Fontes. 1997.

KANT, I. Resposta à pergunta: que é o Iluminismo. In: opúsculos. Lisboa: Edições 70. 1989, p.11-19.

. A paz perpétua e outros Sobre a Pedagogia. $3^{a}$ edição. Piracicaba: Ed. Unimep. 2002, p.11-107.

LEFORT, C. Formação e Autoridade: a Educação Humanista. In: Desafios da Escrita Política. São Paulo: Discurso Editorial, 1999, p. 207-223.

LYOTARD, J. F. Nota sobre o sentido de pós. In: $O$ pós-moderno explicado às crianças. Lisboa: D. Quixote, 1987. 
MATOS, O. C. F. A natureza e o artifício. In: Rousseau: uma arqueologia da desigualdade. São Paulo: M. G. Autores Associados, 1978, p. 45-66.

NOVAES, A. (org). O avesso da liberdade. São Paulo: Companhia das Letras, 2002.

O MÉTODO pedagógico dos Jesuítas: o ratio studiorum. Introdução e Tradução: Franca, S. J. L. Rio de Janeiro: Agir. 1952, p. 5-236.

PLATÃO. A República. São Paulo: Martins Fontes, 2006.

PLATÃO. Protágoras. São Paulo: Matese, 1965.

POLÍBIOS. História: livro sexto. 2 ed. Editora UNB. Brasília, 1985.

RIBEIRO, R. J. A democracia direta. In: . A democracia. São Paulo: Publifolha, 2005.

ROUSSEAU, J.J. Emílio ou da Educação. 2 ed.. São Paulo: Martins Fontes, 1999.

SILVA, F. L. O mundo vazio: sobre a ausência da política no contexto contemporâneo. In: . Maurício Tragtenberg: uma vida para as ciências humanas. Editora UNESP, 2001, p. 239-250.

TELLES, Vera da Silva. Espaço Público e Espaço Privado na Constituição do Social: notas sobre o pensamento de Hannah Arendt. In: Tempo Social; Revista Social. São Paulo, vol. 1, n. 1, 1990, p. 23-48.

VERNANT, Jean Pierre. As origens do pensamento grego. $16^{\text {a }}$ edição. Rio de Janeiro: Difel, 2006. 